\title{
DISSERTATION
}

THE HEART OF THE SCHOOL COUNSELOR:

UNDERSTANDING PASSION OVER THE SPAN OF A CAREER

\author{
Submitted by \\ Timothy L. Sumerlin \\ School of Education
}

In partial fulfillment of the requirements

For the degree of Doctor of Philosophy

Colorado State University

Fort Collins, Colorado

Spring 2009 
COLORADO STATE UNIVERSITY

April 23, 2009

WE HEREBY RECOMMEND THAT THE DISSERTATION PREPARED

UNDER OUR SUPERVISION BY TIMOTHY L. SUMERLIN ENTITLED THE

HEART OF THE SCHOOL COUNSELOR: UNDERSTANDING PASSION OVER

THE SPAN OF A CAREER BE ACCEPTED AS FULFILLING IN PART

REQUIREMENTS FOR THE DEGREE OF DOCTOR OF PHILOSOPHY.

Committee on Graduate Work

Dr. John Littrell, Co-Advisor

Dr. William Timpson, Co-Advisor

Dr. Jenn Matheson

Dr. Laurie Carlson

Dr. Timothy G. Davies, Director, School of Education 


\section{ABSTRACT OF DISSERTATION \\ THE HEART OF THE SCHOOL COUNSELOR: UNDERSTANDING PASSION OVER THE SPAN OF A CAREER}

School counseling is a constantly evolving profession and in view of the growing demands and expectations of students, faculty, parents, the employment sector, and society in the twenty-first century, one that is in need of revision. In recent years the direction of counseling has turned to more accountability and technology, and trending away from some of the vital attributes of the heart, including passion (Palmer, 1998). Many lead counselors, staff development professionals, and administrators find themselves inadequately equipped to engage in and facilitate successful counselor professional development in these areas; school counselors’ work with students, staff, and parents suffer. The aim of this study was to demonstrate the many ways exemplary school counselors have developed and maintained passion over the span of their professional careers. Using a qualitative approach with semi-structured interviews, this study elucidated the key elements in exemplary counselors’ development of passion. Each of nine public school counselors from across Colorado schools participated in a 60 to 90 minute interview in their office and a follow-up email interview. Data analysis included constant comparative analysis with open and axial coding, which produced four emergent themes. Spirituality, humbleness, being out of the office, and a counselor's family, each with supportive sub-themes, emerged from the interviews and are discussed. 
Passionate counselors exhibited deep and textured features of an ongoing spiritual life that resulted in the development of useful attributes and strategies, which in turn resulted in a variety of rewards and recognitions. These attributes, strategies, and rewards created a synergetic relationship. Personal reflections, recommendations, limitations of the study, and implications for possible future research are included.

Keywords: passion; exemplary counselors; humbleness; spirituality; career; life challenges

Timothy L. Sumerlin School of Education Colorado State University Fort Collins, Colorado 80523

Spring 2009 


\section{ACKNOWLEDGEMENTS}

I dedicate this project to my late mother, Catherine. As a child, my Mom dragged me to the local library and thus taught me a love of reading. Her intellectual curiosity sparked a passion for education that lives in me to this day that I have gladly passed on to my children. To my Dad, who has an amazing passion for life and is an exemplary example of living life for all its worth. Thanks Mom and Dad!

I would like to thank the nine passionate counselors I interviewed for this project. You've inspired me and renewed my passion for counseling. You are treasures in the counseling field!

I owe a debt of gratitude and thanks to my committee members who have demonstrated an amazing patience, knowledge, and most of all, passion for my work. John Littrell and Bill Timpson taught me to be a critical thinker and to not accept the status quo. You both took me places I didn’t want to go on my doctoral journey and are my heroes in education. Jenn Matheson and Laurie Carlson supported my ideas, encouraged me, and assisted greatly in the development of this project. Thanks!

Finally my deepest gratitude goes to my remarkable family. Danielle, you did an amazing job of transcribing and listening. Tim, I always looked forward to the drive to Fort Collins because I knew I would see you—thanks for our friendship! I owe so much to Jackie, my wife, for her unending loyalty, the patience of Job, and incessant love through this "mid life" crisis of mine.

Soli Deo Gloria! 


\section{TABLE OF CONTENTS}

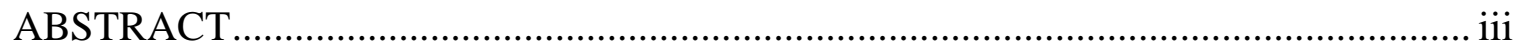

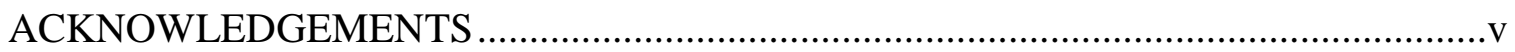

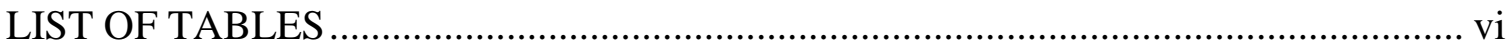

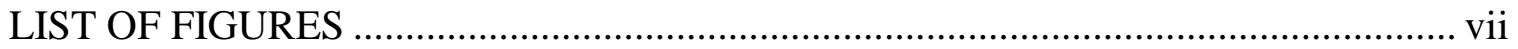

TABLE OF CONTENTS ................................................................................... viii

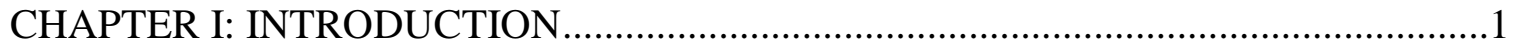

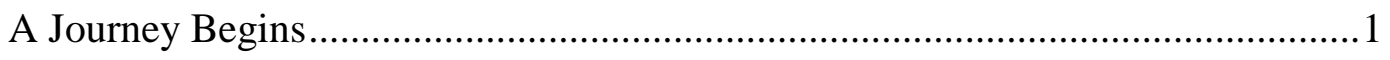

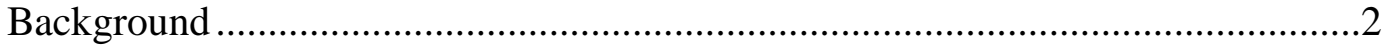

Counselor Roles ................................................................................4

Counselor Preparedness ............................................................... 7

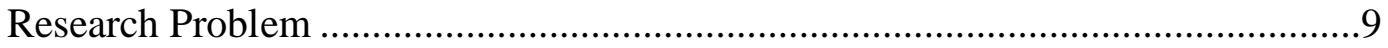

Passionate Leaders ......................................................................... 12

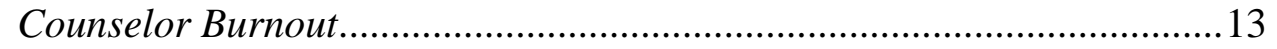

Counselor Training....................................................................... 14

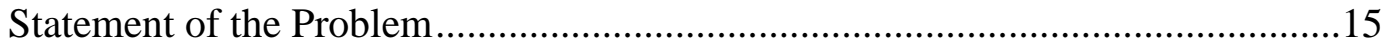

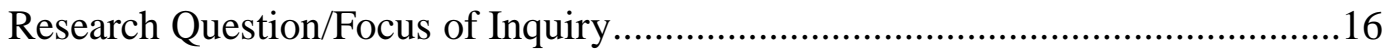

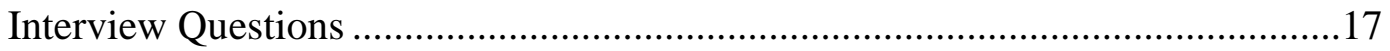

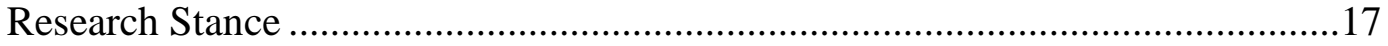

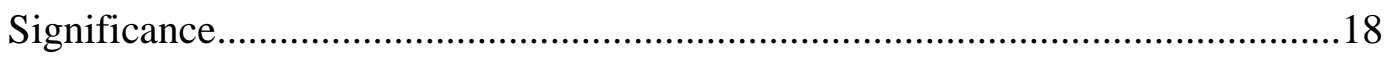

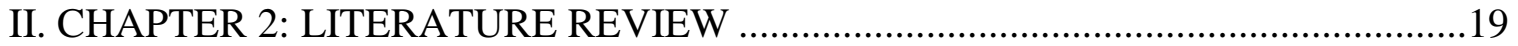


Introduction-The Attribute of Passion

History of Passion...

Passion in the Biological Context........................................................21

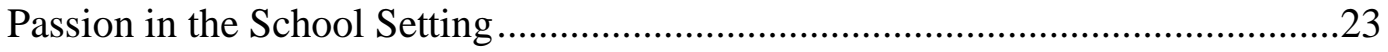

Passion in the School Community........................................................22

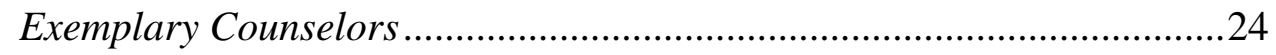

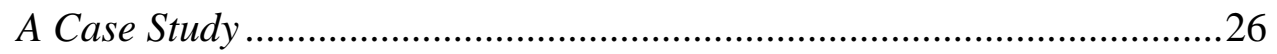

Caring as a Feature of Passion ..........................................................28

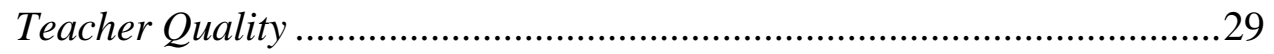

Passion in the Physical Environment .....................................................31

Passion in the Uniqueness of the Individual ............................................32

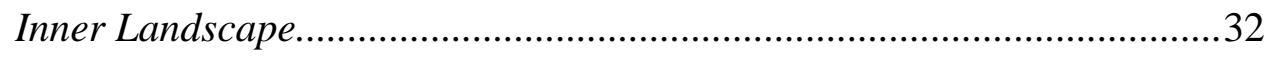

The Passionate Leader ..............................................................................33

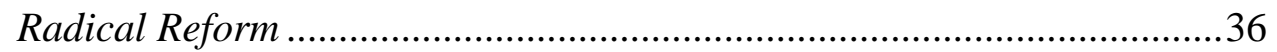

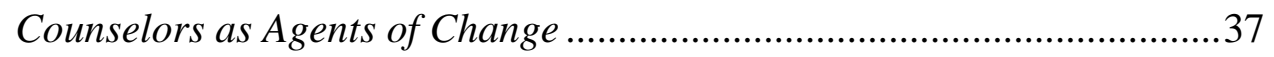

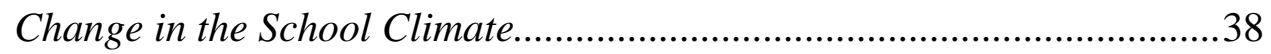

Developing and Maintaining Passion .............................................................42

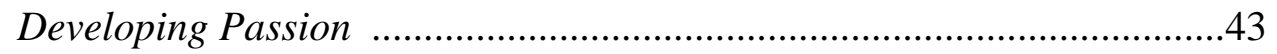

Maintaining Passion .........................................................................44

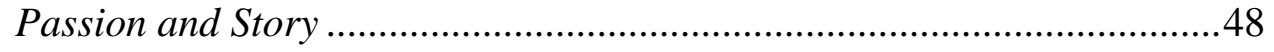

Stress Factors and Burnout over the Span of a Career.......................................50

Stress Factors........................................................................... 51

Life Span Issues...............................................................................5 


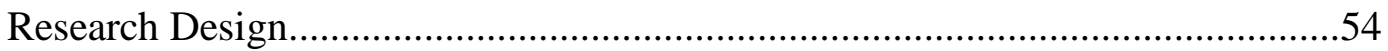

Qualitative Approach..........................................................................5

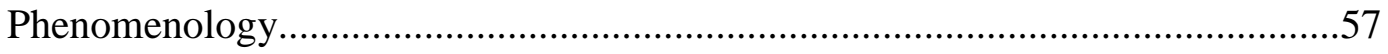

Sampling and Participant Selection .....................................................................58

Research Purpose ..........................................................................................59

Collection, Interview Guide, Questions..............................................................60

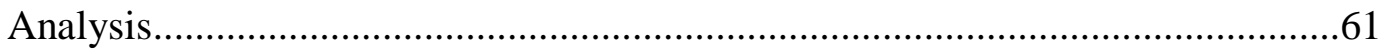

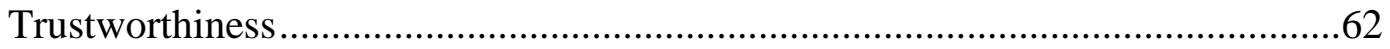

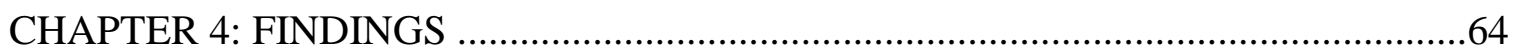

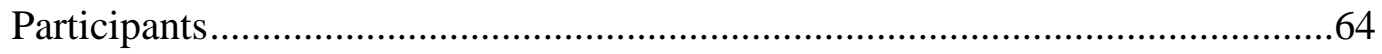

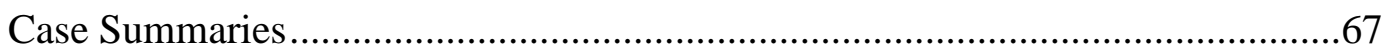

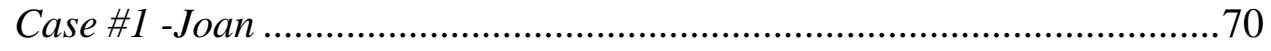

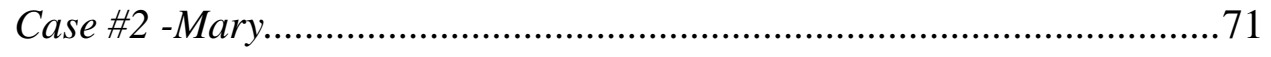

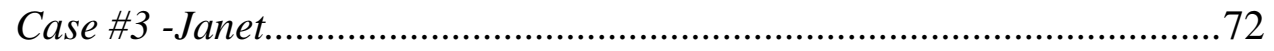

Case \#4 -Sue …………………………................................................73

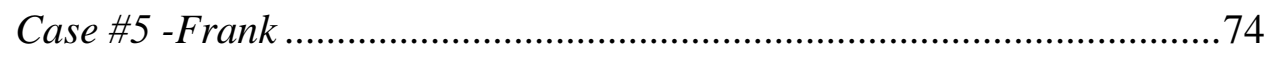

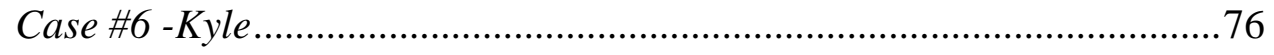

Case \#7 -Kelly ...................................................................................

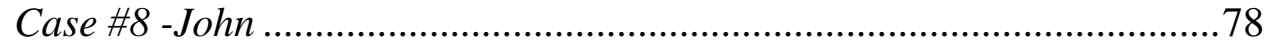

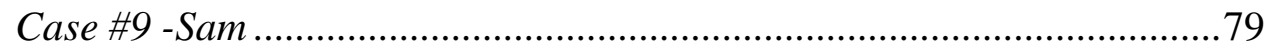

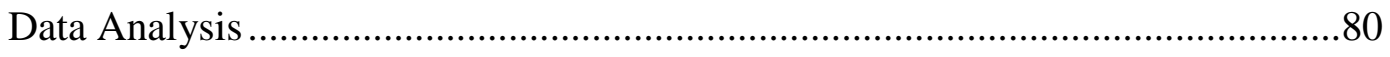

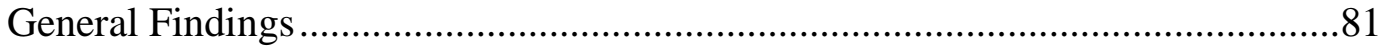


Open Codes

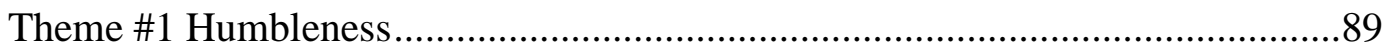

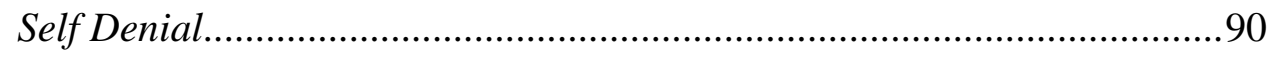

Counseling in a Context.................................................................99

Who Gets the Credit?....................................................................91

Humbleness and Spirituality .........................................................92

Theme \#2 Spirituality/Religion.................................................................83

A Spiritual Relationship.................................................................84

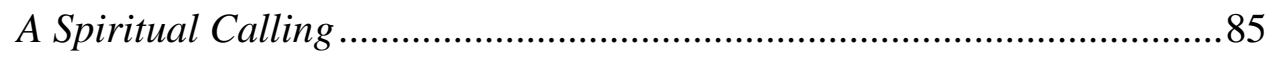

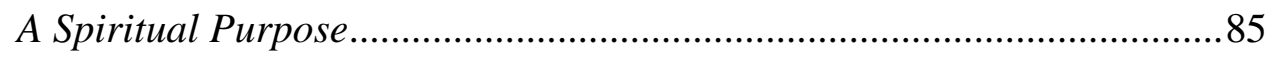

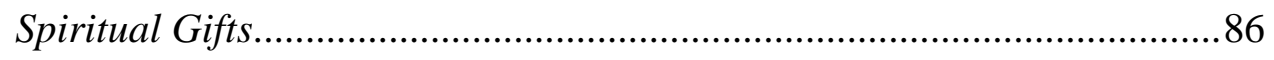

Spirituality as a Help during Challenging Times ...................................88

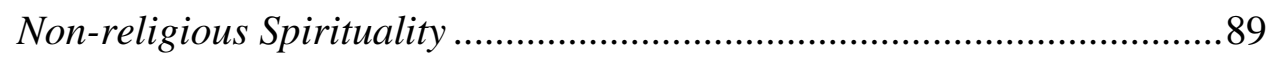

Theme \#3 Out of the Office ..........................................................................99

Physical Appearances and Location of Offices .....................................93

Working Outside the Office...............................................................99

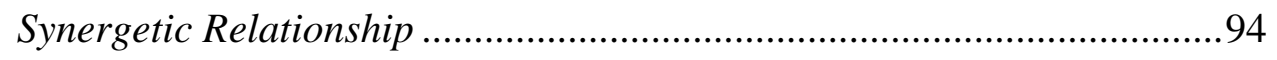

Relationship with Faculty ..............................................................95

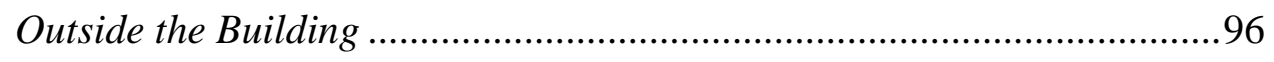

Theme \#4 Counselor's Family ......................................................................96

Raised in a Religious Home ............................................................97

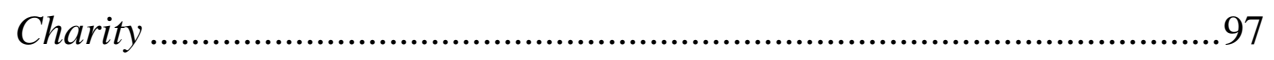

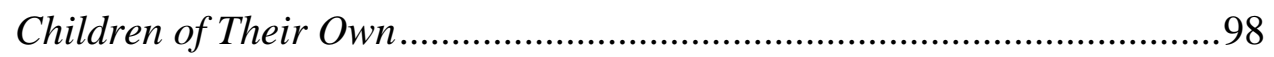




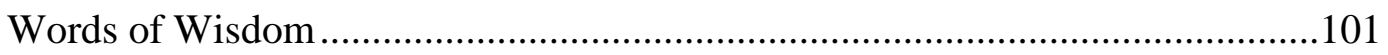

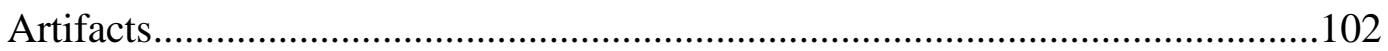

The Passionate School Counselor .................................................................81

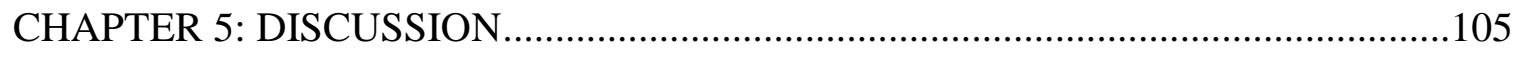

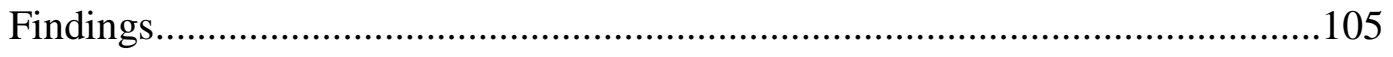

Development and Maintenance of Passion-A Theory .....................................108

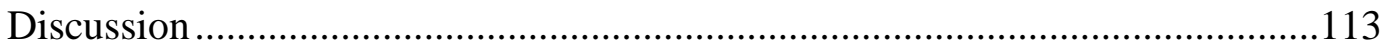

Keeping the Fire Going ..................................................................114

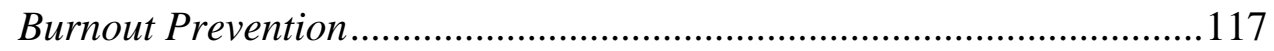

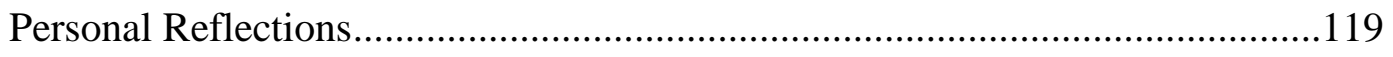

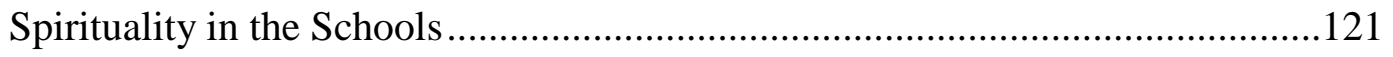

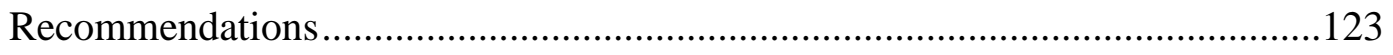

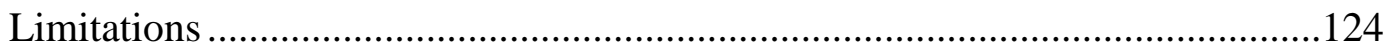

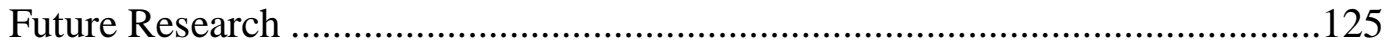

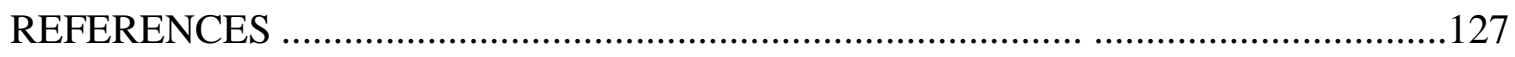

\section{APPENDIXES}

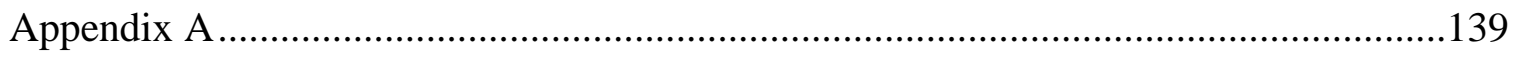

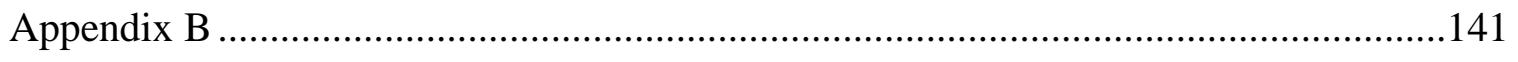

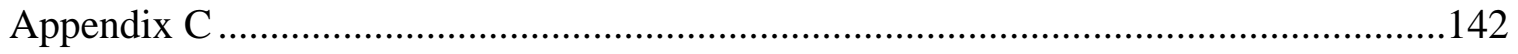

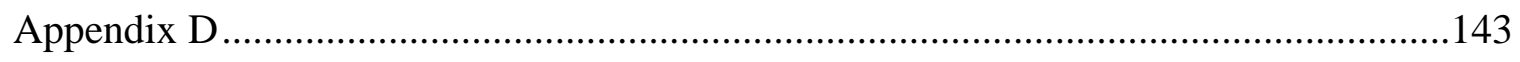

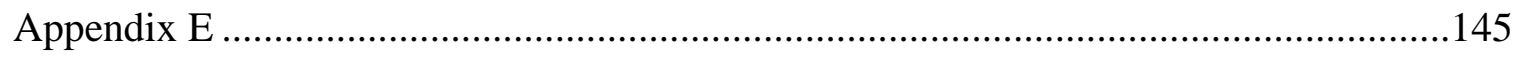

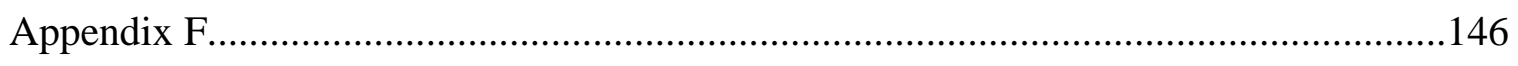




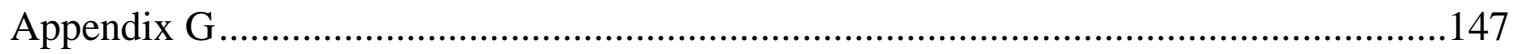

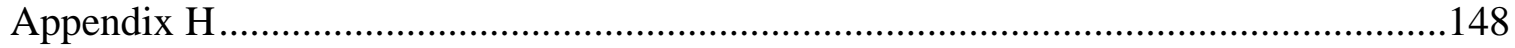




\section{LIST OF TABLES}

1- Schwartz and Loehrs’ Old and New Paradigm on Energy .......................................47

2- Participant, Age, Years Experience in Education and Highest Degree........................66

3- Participant, Age, Years Experience in Education and Highest Degree........................67

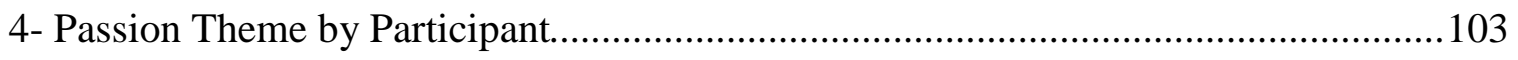

5- Participants’ Artifacts and Perceived Meanings........................................................104 


\section{FIGURES}

1-Theory of the Development and Maintenance of Passion .........................................112 


\section{CHAPTER 1: INTRODUCTION}

\section{A Journey Begins}

The year was 1987 and I was sitting attentively in my very first graduate level counseling course, Foundations of Family Therapy. I was transfixed on the small, elderly professor roaming the room and discoursing on the most basic fundamentals of counseling. I began asking myself questions. What am I doing here? How did I get here? Do I have what it takes to do this for a living? Is this my calling in life? As these thoughts crossed my mind, my professor wheeled around, peered over her shoulder, and looked directly at me. She paused and said, “There's a reason each one of you is in here.” That evening I began a voyage filled with questions such as: Why am I here? What led me to this place? How does my practice reflect my life experiences? What are my passions in life? Do my personal life and professional life passions align? Thus began my journey of how we learn, develop, and grow in passion as a school counselor.

Public schools in America, especially those in secondary education, face a litany of challenges in the twenty-first century, including the testing constraints of No Child Left Behind (NCLB) legislation, increasing use of drugs and alcohol, an increase of both parents working outside the home, divorce, and other challenges (Dahir \& Stone, 2003). The challenge for school counselors to develop and maintain passion is even greater than before (Noddings, 1992) and recent research is showing educators falling behind in this arena (Fitch \& Marshall, 2004; Palmer, 1998, 2004). School counselors hold a unique 
position in the public high school setting as they are trained to meet with students, parents, and teachers for counseling; set up programs to meet a variety of academic, social, and emotional needs; and be an agent for change in a school environment (Fitch \& Marshall, 2004; Littrell \& Peterson, 2005). A lack of passion can cripple a school counselor's ability to effectively work with students, staff, and parents.

Most counselors enter the profession in love with the idea of serving the youth in the community (Liston, 2004), but many, due to life challenges, long hours of work, new work loads, and a sameness in the profession (hooks, 2006; Liston, 2000), lose this fervor over the years. Counselor burnout is at an all-time high (O’Brien \& Casado-Kehoe, 2006) and counselors are continuing to have more responsibilities given to them. Understanding the variety of attributes needed to produce exemplary counselors (Littrell \& Peterson, 2005; Skovholt, 1992), and how they obtain and grow in passion, might possibly increase the effectiveness, spirit, and atmosphere of not only counselors, but the school environment.

\section{Background}

School counseling is an evolving profession and in view of increasing demands, one that is in need of revision (Guiffrida, 2005). The past 100 years has witnessed a plethora of changes within this field. In the early 1900s, school counseling focused on the vocational areas of student growth. Frank Parsons, the "Father of Guidance,” helped to focus the profession on matching the aptitudes and abilities with the proper vocation and environment. In the 1920s, John Dewey ushered in the cognitive development era, with emphasis on the school's role in promoting the student's cognitive, personal, social, and 
moral growth. The concept of "guidance counseling" faded as Carl Rogers introduced a counseling model in the 1950s (Thorne, 1992), which directed the counselor to empathize with a client's understanding of the world and provide a safe environment that would facilitate the client's progress toward self-actualization (Lambie \& Williamson, 2004). Rogers emphasized the counselor/client relationship and introduced concepts to facilitate this relationship, such as empathy, warmth, and genuineness (Rogers, 1961).

The 1960s witnessed a dramatic shift and expansion in the field that was fueled by legislation enacted to enlarge services, augment current programs, improve, and elucidate the role of the school counselor (Schmidt, 1999). This emphasis on legislation was due in part to an evolving society's needs, which included technological changes, changing roles of women in the work force, automation in industry, and a general "accelerated pace of society” (Schmidt, 1999, p. 15). These changes included the Education Act for All Handicapped Children of 1975, commonly referred to as Public Law 94-142, which provided for special education services. Also, these changes exposed a clear lack of theoretical basis for counseling in the schools and counselors began to receive public criticism for a "failure to provide a systematic and carefully organized response to the problems of adolescents" (Schmidt, 1999, p. 21). Some districts around the nation started to lay off counselors and many school counselors began to doubt their role or had difficulty in clearly defining who they were and what they do, experiencing a "shaky theoretical foundation” (Schmidt, 1999, p. 16). Thompson (1992) stated that counselors in the 1970s and 1980s many times were "without a clear definition of mission, purpose or goal" and experienced "role conflict and role ambiguity" (p. 3-4). In a recent study, Baggerly and Osborn (2006) found that, 
When school counselors increase their career commitment, students may benefit by having consistency in the counseling services they receive and thus potentially increasing their academic, career and personal and social success. (p. 204)

\section{Counselor Roles}

The roles of counselors can vary from district to district, and include such responsibilities as educational and occupational guidance, and consultants with teachers, parents, and administrators. Other role responsibilities include dealing with students in crisis, adolescent developmental issues, program delivery (e.g., preventative programs and interventions), and public relations (Bemak, 2000). Thompson (1992) explained that school counselors did not see themselves as "real counselors" and did not measure up to the role experienced by clinical counselors. Thompson concluded with the statement that school counselors cannot "serve two masters—education and psychology" (Thompson, 1992, p. 5).

The shift from vocational guidance to counseling marked an important era in the profession as counselors were called upon to do more and be better trained as mental health providers (Fitch \& Marshall, 2004), which in turn saw the further development of graduate-level counselor preparation programs. These programs began emphasizing more effective and better counseling skills, using a model of teaching counseling theory that emphasized rote memorization of concepts (Guiffrida, 2005). McDonough in Counseling and College Counseling in America's High Schools (2003) summarized this shift by stating:

In recent years, increasing populations of high school students, rising standards, along with a shift in the counselor's roles in special education, administration and an emphasis on equity for every child has demanded that counselors be even more efficient and better trained. Research clearly shows that counselors, when consistently and frequently available and allowed to provide direct services to 
students and parents, can be a highly effective group of professionals who positively impact students' aspirations, achievements. (p. 5)

In 2000 there were an estimated 2.6 million high school graduates; current projections are that American schools will peak at 3.2 million high school graduates in 2008-2009 (WICHE, 2004). Another factor that has increasingly shaped counselors' jobs and made them more vulnerable to administrative demands has been counselors' inability to demonstrate their effectiveness. Recent emphasis on accountability has drawn attention to the need to account for a counselor's responsibilities and for quantifiable data. A lack of evidence and accountability of counselor impact on student learning and development has led to counselors’ susceptibility in times of budget cuts (Van Esbroeck, 1998).

The federal government's Occupational Outlook Handbook (U.S. Department of Labor, 2008) stated that high school counselors, “advise students regarding college majors, admission requirements, entrance exams, financial aid, trade or technical schools, and apprenticeship programs” (p. 6). Research and textbooks on school counseling indicate that counselors' work in schools includes (a) coordination of administrative tasks (e.g., scheduling, testing, and clerical duties); (b) counseling across academic, career, and personal domains; and (c) consultation with all school personnel on guidance tasks (Van Esbroeck, 1998).

The realities of counselor-to-student ratios mean that counselors often have to rely on large group guidance in order to reach, at least minimally, all students (Gysberg \& Henderson, 1997). A recent survey by the College Board (Maucieri, Gernand, \& Patelis, 2002) indicates that the average number of counselors per public high school was 2.7, mostly full-time, but in some cases part-time. A better indicator though, is the counselorto-student ratio found in the typical public high school. The American School Counselor 
Association (ASCA) (American School Counselor Association [ASCA], 2008) recommends an ideal counselor-to-student ratio of 250:1(Lum, 2003). In public schools across America, student-to-counselor ratios are considerably higher than those recommended by ASCA. According to The Condition of Education (U.S. Department of Education, 2004), the national ratio is 284:1, although in larger schools and schools with more than $20 \%$ minority students the ratios are greater than 300:1. Some statewide averages show even more alarming trends, with California as the leader in highest student-to-counselor ratios at 994:1, followed by Minnesota at 800:1, and Arizona with 736:1. No matter what student-to-counselor numbers are referenced, many in the counseling profession believe the numbers are not optimal.

Counselors who view resolving students' social-emotional problems as an important goal are often in conflict with administrators, who seldom identify this task as a fundamental role for counselors (Higgins, 2005). Moreover, as principals' roles have expanded, conflicts have emerged from differing expectations of what duties counselors and principals are responsible for. Many principals have redirected counselors’ roles to include additional administrative duties, such as scheduling and lunch room duty (Bemak, 2000). A recent study indicates the need for counselors to work closely with the school principal in order to achieve maximum effectiveness (Mallory \& Jackson, 2007). Some of counselors' competing roles (e.g., responsibility for enforcing school discipline rules, dress code, inappropriate language in the hallways, and increased testing responsibilities) undermine the counselors' ability to play the roles of advocates and confidants. On a more positive note, this distinctive shift in roles has provided counselors 
with discretionary job options when school counseling positions have been eliminated (Paterson, 2004).

\section{Counselor Preparedness}

Included in this is a recent movement in most states of not requiring counselors to have previous teaching experience, so that many new counselors have had either none or little familiarity with high schools’ unique social milieu (Smith, Crutchfield, \& Culbreth, 2001). Counselors report that upwards of $25 \%$ of their time is spent in individual counseling sessions and that most do not feel adequately trained or inspired (Battistich, Solomon, Watson, \& Schaps, 1997; Lambie \& Williamson, 2004).

Most school counselors, teachers, parents, and administrators can articulate the problems that arise and the damage that comes from neglect of counseling in public schools, and yet counselors are aware that they lack the hard data that could persuade state and local policymakers and district administrators of the need and potential benefits of hiring more school counselors (McGlothlin, 2008). This is especially true during times of budget crisis. The counselors' role in the school environment, and the little quantifiable evidence available in what counselors contribute to the successful school, add to the misperceptions.

Many high school counselors have expressed a lack of personal growth and knowledge in key areas and they struggle with motivation issues, burnout, and frustration at a perceived lack of support from administration regarding professional development (Skovholt, 1992). Moles (1997) found that counselors attend on average three in-service

programs annually across all counseling domains. Hawkins (2003) found that nine out of ten counselors received time off for professional development; however, only $42 \%$ 
received full financial support, (e.g., registration fees, travel expenses). Spending professional development time working on our "inner landscape” (Palmer, 1998, p. 8), (i.e., on the attribute of passion), is often ignored or downplayed as an unimportant focus in relation to the above mentioned research.

\section{Research Problem}

There exist many avenues to accomplish counselor preparation, including coursework, peer interaction, practicum, and the counselor's internship training, which is most vital and a recent report indicates that many recent graduates have experienced insufficient site supervision of internship experiences (Akos \& Scarborough, 2004). The Council for Accreditation of Counseling and Educational Programs (CACREP) has set national standards for the rigorous preparation of counselors that includes the internship experience. These internships are considered to be the most significant experiences of the graduate program (Akos \& Scarborough, 2004). Recent research indicates that internships would do well to require time developing supervising-supervisee relationships and understanding the importance of interpersonal characteristics, such as passion, that a new counselor brings into this social environment (McCalip, 2001).

However important the internship is, counselors do a large amount of professional development while on the job for up to four decades after graduate school. Henderson, Cook, Libby, and Zambrano (2006) stated that being connected to a profession is of utmost importance as a high school counselor develops an identity within the profession. Several developmental tasks must occur over the span of a career that are closely aligned with emotional and mental development (Sheehy, 1995). The majority of typical district 
and school professional training is composed of technical issues, such as scheduling procedures, college admissions counseling, testing, and technological information, as well as district updates and program facilitation. The majority of districts and school principals have no training or programming in place to facilitate this area of professional growth, and few doctoral students have ventured into this kind of research (Reisetter, Korcuska, Yexley, Bonds, Nikels, \& McHenry, 2004).

One major area of concern is how counselors develop, maintain, and grow in the area of passion (Battistich et al., 1997; Liston \& Garrison, 2004; Noddings, 1992; Palmer, 1998, 2004). Many books have been written in the business sector regarding passion and yet little is found in the literature describing passion in the school counseling profession.

Passion can include the attributes of care and love. Care is described by Noddings, not as a character trait, but as “entering into a caring relationship” (1992, p. 18), precipitated by a choice on the part of the caring person (Liston \& Garrsion, 2004). Love is used in this context as a commitment and "the close connected and bonded feelings [that appear] in a loving relationship” (Liston \& Garrison, 2004, p. 40). These attributes can be summed up by the term passion, a strong emotion or feelings, expressed with considerable force; a force that has positive potential and power in communicating thoughts, a power in leadership (Gibran, 1992). Passion is thought of as one’s emotions, that are externally observed, and feelings, which are internally observed; passion is also seen as desire, enthusiasm or their desires, feelings, tactics, and behaviors that persist over time (Frijda, 2006). In Passion for Excellence, Peters and Austin (1985) discussed passion and leadership as something that must be cultivated and that it connotes unleashing power, building, release, and emergent. 
Other factors such as one's childhood, parents, adolescence, personality, current family structure (Sheehy, 1995) all play a role in how a counselor is able to develop and maintain passion. Many counseling graduate programs however, accentuate a modernistic approach, emphasizing rote memory of theory, which is helpful for taking exams and passing certification programs, but do not take into account these above mentioned factors (Guiffrida, 2005). The determination of personal meaning and purpose in the counseling graduate student requires inquiry that moves away from the superficial, because often schools are asking for more from their workforce and employees in turn are asking more from life (Klein, 2001). Investigation and understanding of inner spirituality and one’s calling can lead to greater meaningfulness, contentment, and job-related efficiency (Csikszentmihalyi, Rathunde, \& Whalen 1997; Wrzesniewski, 2001).

Other studies (Henderson et al., 2006; Skovholt, 1992) conducted in similar fashion to this one, indicated that successful school counselors demonstrate a dedication to serving students in their innate environment that is strengthened by a "passion for the work school counselors perform” (Henderson et al., 2006, p. 141). Liston (2000, p. 82) argued for a "transformed, enlarged love," where educators are reopening themselves to the pain, burnout, and rejection in school counseling and uses this concept to regain love for the profession in order to combat this sense of despair that often engulfs the professional school counselor.

While many public school districts pour a myriad of resources and money into teacher and administrator professional development, little is designated for the development of passion for school counselors and how these might influence the school climate. Counselors, along with other faculty, are an influence for the school climate and 
have a unique opportunity to "ensure that a diverse student body can be transformed into a cohesive learning community” (Timpson \& Bendel-Simso, 1996, p. 7).

Passionate Leaders

Leaders who lack passion or feel ensnared, jaded, or intellectually unmotivated do not benefit themselves or the organization (Boyatzis, McKee, \& Goleman, 2002). Without passion, a leader cannot sustain the energy and creativity vital to a school's success. Passionless leaders cannot inspire and motivate others. According to Mitroff and Denton (1999), educational leaders who find a school climate with fewest restrictions on values, emotions, and achievement will more wholeheartedly use their skills to benefit the organization and society. Leaders who understand their passions can assist others in finding theirs while addressing the complete personhood of the employee have produced substantial benefits for schools and students alike (Friedman, Christensen, \& DeGroot, 1998). By understanding our motivations in the context of passion for work and life, teachers and counselors are re-energized, thus revitalizing their classrooms, departments, schools, and communities.

The reality is that counselors are usually lumped in together with teachers on Staff Development days and are required to fit their training into a teaching model. Little research has been done to remedy this, particularly in the high school setting. School leadership should contain elements of moral leadership (Bennett, 2007) as well as an understanding of emotional intelligence (Goleman, 2006). The school leader will face challenges in school culture, relationships, moral questions, cognitive abilities, and managing learning (Bennett, 2007; Timpson \& Bendel-Simso, 1996).

\section{Counselor Burnout}


Change often comes from within the leader (Goleman et al., 2002; hooks, 1994; Palmer, 1998) and will include such areas as "passion and vision, personal values, inner strength and courage, conflict resolution, and harnessing the will of others” (Bennett, 2007, p. 4). Research has indicated that many educators lose touch with their original zeal and begin to experience disillusionment, a sense of despair (Akos \& Scarborough, 2004; Liston, 2000; Liston \& Garrsion, 2004; Noddings, 1992; Palmer, 1998), and can get "stuck along the way" (Henderson et al., 2006, p. 129), which in time can lead to counselor burnout. Liston (2000) summarizes this issue by stating,

In many a teacher's heart there is an enveloping darkness. It is a darkness that may not be as penetrating and pervasive as the clinical depression depicted by William Styron in Darkness Visible but nevertheless amounts to a devastating sense that the education, teaching and life we have clung to with such hope and promise are losing their grip...It is a darkness of the teaching soul...It is a darkness that forgets the landscape and features of teaching. (p. 81)

Burnout, also known as compassion fatigue or creeping fatigue, contains many elements including life span issues, listening to problems throughout most of the typical work day, issues with administration, a perceived or real lack of support, and uncertainty about counselor roles in a given school environment (Butler \& Constantine, 2005). Compassion fatigue, which comes about by listening to another's burdens and traumatic events and conveying compassion day in and day out over many years, can build up and show up after several years (Maslach, 2005), while burnout, which has similar symptoms can occur within weeks or months. Creeping fatigue can be exhibited when a counselor experiences a personal loss or trauma and their coping strategies are compromised, many times due to work stressors. Often their stress goes unrecognized for long periods of time and will eventually show itself as emotional exhaustion, a loss of passion, and lowered standards in professional effectiveness (Maslach, 2005). This will many times lead to 
questioning their own values and purpose in their vocation and a possible exit from the field of education all together.

\section{Counselor Training}

Many counselors' training and theory experiences are limited to books used in graduate school and many have difficulty discussing vital areas of their practice such as: What is my understanding of the larger system of which I am a part and which gives my life purpose? Am I a caring professional which my district values? These are vital questions that many ask as their careers progress (Liston, 2000; Noddings, 1992). One’s counseling theory should be congruent with who we are as a person (Littrell \& Peterson, 2005) and compatible with the school setting. Many counselors, after learning a variety of counseling theories, revert back to what feels natural and do not have confidence in their application of theory (Guiffrida, 2005). They begin to feel burnout, often within a matter of a few years (Liston, 2000).

This study can have important influence on the lives of individual counselors as well as the educational field. Boyatzis et al., (2002) assert that great leaders have the ability to excite followers and that this leadership movement is only sustainable through emotional resonance, defined as a positivist attitude that unleashes the best in students and faculty. Through this emotional resonance, a leader's passion spreads and ignites others' passions and callings (Bell, 1997). School counselors are called on to be leaders in their schools and should understand their place in the school context (Dollarhide, Gibson, \& Saginak, 2008). Counselors who live with passion, defined as a fervent commitment to work for its own sake, are consistently happier than those with mere jobs or careers (Wrzesniewski, 2001). Recent research into the significance of teacher quality 
has shown that the quality of the teacher or counselor in the classroom plays a very important role in student accomplishment (Darling-Hammond, 2000).

Statement of the Problem/Purpose of the Study

The purpose of this study is to explore through interviews how exemplary school counselors develop passion throughout the span of a career, and to identify what inspires them to continue to do so throughout their time in the field. Important issues confront the counselor of the twenty-first century including increasing case loads, theoretical fit, technological issues, and development of passion as well as rediscovering motivation. After years of one-on-one counseling, crisis counseling, schedule changes, conducting testing programs, parental contact, and the myriad of other duties of the school counselor, many are finding themselves in an enveloping darkness and at a loss for energy (Liston, 2000). Passion may seem like a distant memory, and yet these qualities are vital to counselor success. There is a scarcity of literature, however, exploring strategies that counselor educators can use to augment graduate student self-reflection (Guiffrida, 2005).

Leaders who can discover their passion and help others find their callings definitely contribute to organizations and the educational community through specific behaviors (Csikszentmihalyi, 1997) and yet many leaders and potential leaders struggle with their true passions. Some struggle to find their passions in life while others consistently silence the call (Boyatzis et al., 2002). For seasoned leaders, this silence may result in less creativity, less productivity, lack of morale, and a loss of meaningfulness (Boyatzis et al., 2002). Recent research reveals that individual workers who believe they have a calling make their work more meaningful by timing themselves for efficiency, 
priding themselves on meeting needs, and taking extraordinary interest in the outcome of their efforts (Wrzesniewski, 2001). It is important for leaders to know how one determines a calling or passion for work and life and how this sense of calling affects individual and thus organizational behaviors, in order to bring greater meaningfulness to their work, themselves, and others. Missing or misinterpreting a wakeup call can result in inappropriate behavior or a misuse of the contributions we offer in our counseling careers. Heeding these messages and rediscovering passion are worthy goals, which are bound to supply energy to leaders and their colleagues (Boyatzis et al., 2002).

\section{Research Questions and Focus of Inquiry}

While many public school districts pour a myriad of resources and money into teacher and administrator professional development, little is designated for the development of passion (energy, commitment, and enthusiasm) for school counselors. School counselors consistently struggle to find passion in a complex and challenging environment (Baggerly \& Osborn, 2006).

The guiding question in this study was: How do exemplary school counselors develop and maintain passion over the span of a career?

Secondary questions included:

What strengths enable a school counselor to develop and maintain passion during difficult and/or challenging times, through life stages (e.g., marriage, childbirth, parenting, divorce, aging, and retirement), difficult working environments, and demanding workloads? 
How can an individual counselor's passion change the culture of a counseling department and/or school?

\section{Interview Questions}

Interview questions guided this research. The following are the broad categories of research questions.

1. How have you as an exemplary school counselor developed and maintained passion over the span of your career?

2. Describe the role of your family in developing your passion.

3. Use an artifact from your office to describe your passion.

4. How does passion relate to your role as a counselor?

5. How have these attributes been emphasized through professional development in the school or district setting?

6. What role have your relationships played in this development both inside and outside the counseling profession?

7. What advice would you give a first year counselor concerning passion? What might you tell a fellow counselor who is going through burnout?

\section{Research Stance}

As a former Christian church minister, substitute teacher, high school biology teacher, middle school counselor, and now a high school counselor for the past 20 years, I have a personal perspective with which I approached this study. I have had a variety of experiences in education as well as my own personal socio-historical-economic history in 
counseling in both middle school and high school settings. Most of these settings have lacked some crucial areas of diversity (Timpson, 2003). As a researcher, it is important to acknowledge that I have spent the past 26 years in various lay ministry roles in a somewhat conservative Christian church; much of my background in passion is also based on my experiences in this tradition, the Scriptures (The Holy Bible New International Version, 1984), and in my personal faith.

\section{Significance}

Is passion a vital component in the counseling center in the public school setting? Is the counseling center the best place to demonstrate this attribute? Is modern pedagogy in the graduate level counselor preparation programs useful to develop passion? Should school and district administrators offer specific professional learning opportunities involving passion for their school counselors? These questions lie at the forefront of today's counseling profession and may help lead the way into a more productive decade of counseling if researched, addressed, answered, and applied. Therefore, the purpose of this study is to discover themes in the development and maintenance of the attribute of passion among exemplary school counselors. 


\section{CHAPTER 2: LITERATURE REVIEW}

The Attribute of Passion

Mary Reidel, principal of Rockwood Valley Middle School in Wildwood, Missouri, in the mid 1990s, was a different kind of principal-one I had never experienced before in several years of teaching and counseling in the public school setting. She was energetic, bright, articulate, and charming-she seemed to be everywhere at once and knew something about everything and everyone in the school. Her passion was evident to all who came in contact with this dynamic, energetic, and fiery leader. Her lithe and vibrant body appeared to have boundless energy whether she was in her office, my office, the lunchroom, classrooms, or hallways at Rockwood Valley_she was the first to arrive in the building most mornings and many times one of the last to leave in the evening. She seemed to have an aura around her and when she spoke she commanded attention from students, parents, and staff and usually added to the conversation in a powerful way. Mary not only exhibited energy and passion, she also communicated and conveyed it - that is, she passed it along to others in her presence. I usually felt more energetic after being with her and often wondered if she ever wore down or experienced burnout. I was never quite sure what she would bring into a meeting, but I knew I would usually walk out a different person-a better counselor, more focused, energized, and usually more motivated. My curiosity was piqued. What is 
passion, what is its role in education, and more importantly, how does one develop and maintain this "power"?

\section{Introduction to Passion}

Passion can be found everywhere. Movies glorify it, books and articles have been written about it, researchers research it, and consultants educate businesses about how to obtain and use this vital attribute (Zaltman, 1996, 2003). An entire health food and vitamin industry has exploded around energy (e.g., energy drinks, energy bars, herbal concoctions, and health clubs). As people age, many seem to lose passion or see its effects dwindle (Sheehy, 1995). It is often misunderstood as mystical or elusive and when not coupled with wisdom, integrity, and knowledge, at times can be abusive. Too much passion can lead to burnout and break-down and too little can lead to atrophy and weakness (Loehr \& Schwartz, 2003).

Passion has been written about extensively in the social sciences, psychology, and in education (Goldstein, 1999; Liston, 2000; Liston \& Garrsion, 2004; Loehr \& Schwartz, 2003; Loehr, 2007; Noddings, 1992; Palmer, 1998, 2004; Peters \& Austin, 1985;

Skovholt \& Jennings, 2004). In the area of education, passion can be described as an educator's love for ideas, love for educating others, and a love for students; "passion is what separates the great teachers from the forgettable ones” (Liston, 2004, p. 43). Words such as energy, desire, enthusiasm, emotions, and motivation are often used to describe passion. Passion can sometimes be referred to as "desires, behaviors and thoughts that suggest urges with considerable force” (Frijda, 2000, p. 6) that continue over an arc of time. 


\section{History of Passion}

Passion has its historical roots in the early works of Western philosophers, especially Greek philosophers, and came to represent what we now refer to as emotions. Philosophers believed that passions and emotions were in conflict with reason and we have the need to perfect our ability to reason while limiting our indulgence of our passions (Marinoff, 2003). Later, Hume and others taught that passions could motivate our behaviors, whether good or bad, in ways that reason could not, and that we ought to spend a significant amount of energy harnessing its power in our lives (Frieda, 2000). The term passion has appeared numerous times over the centuries in a variety of ways, including historic works of poetry, history, and drama as well as including the suffering and anguish associated with Jesus' crucifixion on the cross, described in Christian theology.

\section{Passion in the Biological Context}

In the biological context, passion is a process that is either an emotion (i.e., externally observed) or a feeling (i.e., internally observed) and is influenced by events and circumstances. Emotions or feelings arise from sites in the brain and can influence cognitive processing, either consciously or subconsciously (Damasio, 1999). Pinkerton (1997, pp. 412-413) argued that there is an "apparent firewall” that is erected between reason and passion in our brain that acts as a guarantor for responsible behavior (i.e., reason can control passions). Recent scientific studies argue for the need of emotions in proper decision making,

It is clear now that the two great domains, reason and passion, are both critical to our ability to make proper decisions. Emotions unchecked by reason can lead to disaster, but without emotion, a person is unable to plan properly or form and sustain social bonds, even in the presence of adequate reasoning ability...When 
passion and reason work well together, like the partners in a successful marriage, the outcome is happy one. When they are at war, like hostile spouses, the result is no end to grief. (Rosenthal, 2002, p. 31)

Passion has also been associated with various types of romantic love, including infatuation, romance, our commitment to love, intimacy, and curative factors (Strongman, 1996). In addition, passion is closely linked to spiritual concepts. In the Buddhist tradition it is linked to a spiritual awakening (i.e., the ability to manage pain and suffering with ease and to understand one's place in the universe) (Rubin, 2006). In the religions of India, passion, or the attempt to control our passion, is seen as an even higher calling than our quest for food and shelter (Polanyi, 1958). Judeo Christian theology equates passion with the concept of zeal and describes it as the ability to obey the words of God despite personal or cultural norms that differ significantly (e.g., the story of Phinehas' zeal in the Old Testament book of Numbers) (The Holy Bible, 1985). Rockwell argued that we create our relational reality based on our passions and this passion "helps us to speak from our hearts and can draw out other people and engage them...this sense of pleasure and promise magnetizes others” (2002, p. 52). Passion is such a powerful force that he insists people "have to engage their passion without losing sight of the danger of getting caught up in or intoxicated by it...we don't want to eliminate their passion; we want to cultivate it, refine it” (2002, p. 184).

Finally, the Oxford Dictionary described passion as a noun: (1) as a strong, barely controllable emotion, (2) a fit or outburst of such emotion, and (3) a literary composition or passage marked by strong emotion; an emotional speech. Passion is also described as a verb: (1) to excite or imbue with passion or to express, and (2) to be effected by passion or a strong emotion, formerly especially sorrow (Oxford English Dictionary, 2002). 
In this chapter I will review the literature on passion and will discuss: (a) passion in the school setting, (b) how individuals develop and maintain passion, and (c) stress and burnout factors that affect one’s passion with career and life span issues.

\section{Passion in the School Setting}

The hallmark of the community of truth is in its claim that reality is a web of communal relationships, we can know reality only by being in community with it.

$\sim$ Parker Palmer

Passion in the school setting can take many forms. Passion may look like a teacher reaching into her soul for more energy and love to assist an uncaring and distracted teenager; a principal walking the hallways and picking up trash or going beyond district expectations in creating a new teaching model to help kids and energize teachers; counselors who tear away from the bonds of paperwork, scheduling, and testing analysis to create proactive, school wide programs, which energize faculty and students alike; janitors and lunch room employees who serve with concern and care; or faculty fed up with the status quo serving on after-school committees and pushing for district or building-wide reform. Passion can be seen in teachers, counselors, and administrators who energetically show up every day for decades with a quiet zeal that often goes unnoticed. Passion in the school setting can be seen in school community, the uniqueness and individuality of faculty, and in creating and moving radical reform. This is consistent with Wiggins and Moody's (1987) findings that counselors who were rated as more effective were mostly involved in direct delivery of counseling services, whereas those rated as ineffective spent more time on clerical activities. 


\section{Passion in the School Community}

Passion is seldom viewed as solely an individual trait. Much of what has been written about passion includes the social context and passion, by its very nature, extends to those who surround us and interact with us. This attribute has taken front stage in recent publications in the business field (Buckingham, 2007; Buckingham \& Clifton, 2001; Goleman, Boyatzis, \& McKee, 2002; Loehr, 2007; Loehr \& Schwartz, 2003; Peters \& Austin, 1985; Zaltman, 1996, 2003) and in the field of education (Fitch \& Marshall, 2004; Goldstein, 1999; Henderson et al., 1999; Liston, 2000; Liston \& Garrsion, 2004; Noddings, 1992; Palmer, 1998, 2004; Timpson, Borrayo, Canetto, \& Yang, 2003) where the implications for development and maintenance of passion co-mingle. Henderson et al. (1999) stated, "School is where it all makes sense” (p. 130), that is, in the social context of a school building with community, parents, district personnel, building administrators, peer faculty, support staff, students, and curriculum, where passion is developed, expressed, and ultimately has meaning.

The school community contains a group of individual counselors with a "common interest” (Henderson et al., 1999, p. 137) and includes such concepts as a sense of connectedness and sustainability, a medium for growth, and mutually respectful dialogue among professionals that reinforces, challenges, and nourishes a professional character and the healthy development of identity. An educator who is making an impact on a campus is often characterized as having creativity, energy, and spontaneity (Timpson \& Burgoyne, 2002) and is always ready to change in response to the ever shifting sands of public education. 


\section{Exemplary Counselors}

Exemplary counselors find themselves in a social context where they have focused over time on peer relationships, mentored support, defined multiple roles, and implemented a healthy working environment (Skovholt \& Jennings, 2004). Becoming an active part of this kind of passionate community involves counselors initiating change within themselves and among their peers and students. Making changes and reminding themselves of the joys of counseling will result in "students responding positively to your energy and enthusiasm” (Timpson \& Burgoyne, 2002, p. 159).

In a recent study of 63 high performing schools, counselors were found to spend the majority of their time on program administration, synchronization, and aligning programs with professional values (Finch \& Marshall, 2004). Counselors have the position, skills, and abilities to affect change on the school campus by addressing threats to the school culture and they can serve a special role in acting as a collaborator with students, teachers, and administrators. In addition, they have the knowledge and resources to access community and parental support.

Exemplary counselors have the ability to work within a school culture in order to change it and can energize students by their passionate engagement (Timpson \& Burgoyne, 2002). They can address areas such as change, school rhythms, morale, differing perspectives, implicit rules, roles, the surrounding environment, and work. These exemplary counselors view the school culture and environment in such a way as to “recognize its inherent strengths and limitations and are open to opportunities within it, and determine how to manage their work there” (Littrell \& Peterson, 2005, pp. 53-62). 
Since describing passion on a school wide level comes with difficulty, I have found it useful to include a mission statement from Brookline High School, which was initiated by the school principal and then created by the faculty after months of serious debate, study, and discussion.

School Philosophy of Brookline High School: A Case Study in Passion

\section{Using a Mission Statement}

\section{Education Presumes a Climate of Care}

The schoolhouse must be a kind of home which offers it inhabitants a sense of belonging, of individuality strengthened by expectation, of security born of respect. As in the home, the student should feel known but revered; the teacher, exposed but esteemed. Reason for excellence need not preclude acceptance of human foibles; neither should devotion and understanding be devoid of rigor. Care is by nature compensatory, seeking to provide that which would otherwise be lacking.

2. Thoughtfulness is the Social as Well as the Intellectual Aim of Education The habit of reflection is the ideal trait of the educated mind, taking for its concern what others may be satisfied to take for granted. Education should foster this habit, should teach us patience in the understanding and construction of ideas. But it should teach us to consider feelings, to anticipate the probable effect of our actions and words on others, and to temper these when they augur injury.

Education is thus forethought rather than afterthought, abiding thought rather than sporadic thought. 


\section{No Style of Learning or Teaching Is Privileged}

Learning and teaching are two sides of the same coin. Both rely on a sense of timing, a state of readiness, a heightened sensibility which enables one to see or say or think something not seen or said or thought before. Readiness is achieved in different ways, depending on what there is to be learned. Sometimes it requires painful and protracted effort-thinking, reading, watching, writing, talking, and doing. Other times it is attained effortlessly, almost inadvertently. Either way, timing is critical. Knowing how to learn or how to teach essentially knows when to press and when to wait. Styles of learning and teaching are characterized by their sense of pressure and patience. Thorough education will expose teachers and students to a range of styles so that they come to know their own.

\section{Learning Is a Mixture of Pleasure and Pain}

The love of learning is an acquired taste, an addition for the tart rather than the sweet. To learn is to change, and to change can be both exhilarating and wrenching. As creatures of habit, we must approach learning with trepidation, not expecting those who learn to experience a smooth trajectory of triumphs, not those who teach to effect unrelieved excitement about their subject. While it is true that what most easily learned is usually hardest taught, it is also true that love of learning cannot be taught; it can only be exemplified. As is so often averred, teaching requires patience. Let it be said that what teaching requires, learning must learn. 


\section{Education Examines Not the Individual but the Species}

The value of learning lies not so much in its immediate utility as in its generality. Schools are instituted and maintained to serve their communities as havens of learning, not as microcosms in the marketplace. Here, students are apprenticed to life in its ideal form, like that is devoted to inquiry, touched by beauty, informed by justice, guided by reason, girded by simplicity, and graced by elegance. At the very least, graduates should exhibit competency in the exercise of certain skillscomputation, composition — but the aim is to make them literate about the full array of human achievement, so that they will know what it means to do anything well. (Peters \& Austin, 1985, pp. 395-397)

\section{Caring as a Feature of Passion}

When discussing a passion for excellence in the field of education (Noddings, 1992) many leaders (e.g., principals and district administrators) presume a climate of care exists in the school environment (i.e., a sense of belonging and of being strengthened as an individual). Schools must become caring communities, where students and faculty have a basic sense of belonging; members care about and support each other, identify with the community, and have common goals, norms, and values, in order for academic, social, and emotional growth to take place (Battistich et al., 1997). Care, a fundamental human need that is urgent and pervasive (Noddings, 1992) can be thought of occurring in a caring relationship, that is, a decision to engage in others' lives in order to benefit them. People, thus do not simply happen to be caring individuals by nature or personality but decide to engage in caring interactions that can vary among persons and situations. Dan Liston stated, “We believe learning to love, nurture, and care for students' emotions, as 
well as for their thoughts and actions, is everyone’s work in every sphere” (2004, p. 14). He goes on to describe this as an "intimacy-in-community" (2004, p. 40), which embodies trust, a sharing of significant experiences among students and teachers alike.

Membership in this community allows for a sense of support, being valued and challenged, and to do likewise for others. This occurs in an environment of creating a safe place to ask questions and take risks, while demonstrating respect for all learnersteachers and student learners alike (Liston, 2004). Liston argued for teaching and expecting this collaboration model in the school setting as pre-service instruction in teacher education. Noddings (1992) questioned the use of academic competition among students and its use in creating community and competent, loving, and caring people. Some schools recognize this need by instituting community service requirements for graduation, but this often becomes just that—a requirement, without the spirit and heart of a lifelong learning to care. Caring in the school setting is all about relationships among students, teachers, counselors, administrators, and support staff. Noddings (1992) concluded this thought with,

When we discuss teaching and teacher-learner relationships in depth, we will see that teachers not only have to create caring relations in which they are the careers, but that they also have a responsibility to help their students to develop the capacity to care - care is inevitable; all aware human beings care. It is the mark of a human being. (p. 18)

\section{Teacher Quality}

This school culture, environment or ambience (Goodlad, 1984) is reflected in non-academic areas, such as peer relationships among students and staff, behavioral issues among students, parental involvement and support, teacher and staff satisfaction, and a sense of a progression in improvements. The literature regarding teacher quality 
and what defines a quality teacher has become more extensive in the past few years. The requirement in NCLB that all students have a highly qualified teacher by May 2006 has engaged educators and the general public in conversations about what constitutes quality teaching and a quality teacher. Because the definition of a quality teacher varies greatly among the general public, researchers, politicians, and educators themselves, a single definition is difficult to reach; however, there are some commonalities among educational advocates in this area. Hanushek (2004), a leading educational economist, defines teacher quality this way, "good teachers are ones who get large gains in student achievement for their classes; bad teachers are just the opposite” (2004, p. 3). This definition, in its simplicity, gets directly to the point of what quality teaching entails—advancing student achievement. When people talk about quality teachers they are usually talking about teachers who influence student achievement through one method or another.

In a study from the state of Texas, Rivkin, Hanushek, and Kain (2000) concluded, following a far-reaching analysis of data, that "having a high quality teacher throughout elementary school can substantially offset or even eliminate the disadvantage of low socioeconomic background” (p. 3). Moreover, they determined that teacher quality varies from school to school and that family factors could be ruled out as determinants of student accomplishment when these factors were used in their equations. In fact, they reported that having a quality educator five consecutive years would almost make up for the imbalance regarding the differences in academic success for students in diverse socioeconomic groups. The authors concluded that high quality educators are paramount to student success. 
Peters and Austin (1985) believe that passion for excellence also assumes that thoughtfulness is the social as well as the intellectual aim of education and is a habit of reflection; "education is forethought rather than afterthought; it is abiding, rather than sporadic” (p.395). They stated that no style of learning or teaching is privileged and both rely on a sense of timing, a state of readiness. So passion is not an attribute that is stumbled upon or is an inherent trait, but rather one that is worked on and developed (Goleman et al., 2002).

Palmer (1998) called the challenge to develop passion a problem, not in the structure of a building or organization, but a problem of the hearts of individuals. He stated,

Good teachers possess a capacity for connectedness. They are able to weave a complex web of connections among themselves, their subjects, and their students so that students can learn to weave a world for themselves. The connections made by good teachers are held not in their methods but in their hearts - meaning heart (Palmer's emphasis) in the ancient sense, as the place where intellect and emotion and spirit will converge on the human self. (p. 11)

Passion and the Physical Environment

Passion in the school environment can be seen in the focus on the physical surroundings. From industry leaders to education leaders, most were found to be concerned about the physical details of their environment (Peters \& Austin, 1985). Leaders seem to use this visualization intuitively, getting in their mind what they want to achieve, and then setting about to create that picture in the buildings, whether it be framed pictures in the hallways, kept up grounds, the dress code for boys and girls, or dealing with any graffiti found. In similar fashion, a study done in New York in the 1980s discovered the Manhattan Effect (Kelling, 1996). Researchers found that normally decent 
people, not prone to vandalism, who walked down a street, were more likely to break windows or litter the streets; that is, they took their cues of how to behave from their surroundings.

Consider a building with a few broken windows. If the windows are not repaired, the tendency is for vandals to break a few more windows. Eventually, they may even break into the building, and if it's unoccupied, perhaps become squatters or light fires inside. Or consider a sidewalk. Some litter accumulates. Soon, more litter accumulates. Eventually, people even start leaving bags of trash from takeout restaurants there or breaking into cars. (Kelling, 1996, p. 3)

With Mayor Giuliani at the helm in New York City, a massive effort began to deal immediately with any visible destruction. The mayor ordered maintenance crews to wash off graffiti nightly from the subways and even though it appeared again the next day, he continued to proceed with his vision of a cleaner, safer, and more appealing New York. Eventually citizens began to act like the vision they saw and the graffiti was greatly reduced. Because of the vision and passion of the mayor and others, New York is today much safer and a cleaner city to visit (Hinkle \& Weisburd, 2008).

\section{Passion in the Uniqueness of the Individual}

A collection of individuals with common goals make a community. Those who labor in the school setting find themselves standing at the dangerous crossroads between their private, social, and public self_-“a daily exercise in vulnerability” (Palmer, 1998, p. 17). To interact constantly with growing and chaotic teenagers is to put oneself in a mix of emotions, hormones, experimentation, and discovery, which seemingly changes by the minute. One physician acknowledged that teaching in the school setting is more difficult than the routine, daily surgeries he performs on patients' injured shoulders. He stated that his medical practice is predictable and typically highly successful, while education is 
usually unpredictable, sometimes difficult to cite successes, somewhat chaotic, and much more complex with respect to the application of love, care, and concern (Noddings, 1992).

\section{The Inner Landscape}

Palmer discussed the journey through our “inner landscape” (1998, p. 3) and how one cannot teach or counsel effectively without paying attention to and practicing one’s profession from who you are, (i.e. from the inside out). Palmer goes so far as to say one may damage those involved if teachers do not teach from the heart or the self. Educators bring their backgrounds, experiences, and biases into the classroom and pass them along to their students. Palmer made a strong argument for the need to continually work on the inner self-the true self_-and emphasized the connections we make when we teach from the heart. Palmer also states, “To teach is to create a space in which the community of truth is practiced” (1998, p. 90).The educator is the model of learning and a catalyst for student growth and change. Timpson (2002) summarized this point by reminding educators that our students value the passion their professors bring to a group of students in the classroom and to their subjects.

\section{The Passionate Leader}

Vital in leadership, passion is contagious in the work environment. The most passionate are those who suffer the most; who have "risked their independence, their fortunes, their health, and sometimes their lives for people and a purpose beyond themselves” (Kouzes \& Posner, 1993, p. 232). In Passion for Excellence, Peters and Austin (1985) discuss passion and leadership as something that must be cultivated, and that passion connotes unleashing power, building momentum and is a growing force. 
Passion is "rhythm, vision, energy, empathy, persistence, passion, attention to detail, a picture of the goal...” (1985, p. 409).

Another critical concept in discussing passion and leadership is that change can come from within the leader (Goleman et al., 2002; hooks, 1994; Palmer, 1998) and will often include such areas as enthusiasm and imagination. Also, personal values, inner strength, and courage, along with conflict resolution and harnessing the will of others, indicate this change from within (Bennett-Goleman, 2001). Palmer made the distinction between simple technique and true teaching from the self, the heart, and soul, by reminding us that "technique is what teachers use until the real teacher arrives" (Palmer, 1998, p. 5) and "good teaching requires that we understand the inner sources of both the intent and the act” (Palmer, 1998, p. 6).

Peters and Austin (1985) continued with these thoughts about passion, by describing Frank Boyden, a passionate leader in a private school in the Northeast, Deerfield Academy, who founded the school in 1902. He,

continues his work with no apparent letup, sharing his authority by the thimbleful with his faculty, traveling with his athletic teams, interviewing boys and parents who are interested in the school, conducting Sunday night vesper services, writing as many as 70 letters a day, planning the details of new buildings, meeting with boys who are going home for the weekend and reminding them of their responsibilities to the older traveling public, careering around his campus in an electric golf cart, and working from 7 a.m. to midnight every day. If he sees a bit of paper on the ground, he jumps out of his cart and picks it up... (Peters \& Austin, 1985, p. 393)

Boyden, at age 86, was once found heading out to the football field around midnight in the rain to replace grass divots created during the afternoon practice! A passionate leader is a person with "a universal concern for civility, order, and structure" (p. 97) and will challenge complacency by breaking up fights in the hallways with his 
own anger; these passionate leaders are "showmen, visionaries, masterly users of symbols, and super salesman” (p. 398).

These leaders seem to be physically in motion much of the time, known as managing by wandering around (Peters \& Austin, 1985), such as pacing a room instead of sitting behind a desk. By wandering around, a leader manages, coaches, and incorporates a hands-on approach. It is an art that results in the ability to listen, teach, and facilitate with others in the organization. By wandering around, staying in touch, and keeping out of the office, these passionate and energetic leaders are out in front and they practice their leadership intuitively. Oddly enough, many times these particular leaders spend a fair amount of energy figuring out ways to circumvent policies and directives that they believe distort the educational experiences of teachers and students. Even though the principal finds the external intrusions pernicious, he recognizes why they are necessary in a large, diverse, city school system. This leader believes that policies were established to monitor the poor schools, the ineffective administrators, and the lazy teachers. Therefore, in trying to protect against substandard schooling and those leading those schools, central authorities have limited the autonomy of the better schools and distorted the important human encounters that form education. This speaks to the need to unleash good leaders and enable them to pursue worthy endeavors and not be tied down by bureaucratic encumbrances.

Peters and Austin stated that "I have always found the more power you give people, the more responsibility they take" and that in doing so they develop "rhythm, vision, energy, empathy, persistence, passion, attention to detail, a picture of the goal” (1985, p. 408). In doing so, Boyden, the principal, actually developed the character of the 
school in which he was a leader. Peters and Austin (1985) summed up this kind of energetic leadership with the following thoughts:

Education assumes a climate of care: sense of belonging, of individuality strengthened by expectation.

Everyone makes a difference: no matter how unproductive the organization is; do I add or take away from fellow employees’ experiences/organizational goals? Do I ease others' burdens?

No one can prevent me from being extraordinary; most people have a passion for importance.

Sanborn (2004), in his book on passion, The Fred Factor, cited Martin Luther King,

If a man is called to be a street sweeper, he should sweep the streets even as Michelangelo painted or Beethoven composed music or Shakespeare wrote poetry. He should sweep streets so well that all the hosts of heaven and earth will pause to say, 'Here lived a great street sweeper who did his job well' (Sanborn, 2004, p. 65).

Passionate leaders must deal with mediocrity in the school environment and fight against a willingness of others to do just enough to get by. Other practices of the passionate leader include the ability to tell the truth while practicing personality power. They must look to meet needs in advance, add enjoyment, enthusiasm, humor to the school culture, and subtract the negative like unnecessary waiting, unneeded defects, undisciplined mistakes, annoyance, frustration, and misinformation (Sanborn, 2004).

In concluding this section on the uniqueness of the individual, I quote one unique man who came on the world scene at an important time in history, Winston Churchill: 
There comes a special moment in everyone's life, a moment for which that person was born. That special opportunity, when he seizes it, will fulfill his mission-a mission for which he is uniquely qualified. In that moment, he finds greatness. It is his finest hour (Churchill, 2003, p. 219).

\section{Radical Reform}

Education in America is striving to change and with technology's rapid rise in influence, change is inevitable (House, 2002). While major reform has focused on accountability, such as the emphasis on No Child Left Behind legislation, more reform can and will take place. However, school counselors have historically not been a part of school reform. The reasons seem to be varied and many. They include a lack of preservice training, confusion regarding counselor roles, over-accommodating counselor behavior, pressures from the school, and limited professional development opportunities (Bemak \& Chung, 2008). Also, counselors' isolation from the rest of the faculty, hesitancy to voice concerns, and previous limited involvement in school reform all contribute to this absence of counselors in school reform (Adelman \& Taylor, 2002). Counselors as Agents of Change

If counselors lack a clear and concise vision for their roles and see themselves as a marginalized group, then they will continue to serve as "maintainers of the status quo" (House, 2002, p. 2). Counselor educators have not traditionally designed their programs to teach advocacy skills and systemic participation and can be weak in teaching how to challenge a school system or climate (Bemak \& Chung, 2008; Littrell \& Peterson, 2005). However, counselors can see themselves as agents of change in their school environment. Because they advocate for high student achievement, they are at the heart of the mission of education and educational change (Darling-Hammond, 1993). 
One key to a change in counselors becoming more involved and energetic reformers is a change in counselor education programming, that is, helping counselors examine their personal beliefs about reform, redefining the counselor's role in the learning community, teaching advocacy skills directed for change within a school system, and, through counselors in the field, stepping up to passionate counselor leadership (Dollarhide et al., 2008). In view of a counselor's ability to ascertain and discuss the interpersonal attributes needed in educational reform such as emotional development, it is imperative that the counselor become involved with school reform on both the national level but maybe even more importantly on the school level. As House (2002) said, ....as leaders and advocates, counselor educators and school counselors need to reexamine recurrent professional role patterns and think in a more systemic fashion. They must reach and influence people beyond their jurisdiction, have political skills to cope with conflicting requirements of multiple constituencies, and question the status quo... who can practice as leaders and advocates to influence the attainment of high achievement for all students, aligns school counselors with educational reform, and places them in the middle of the changes needed to support all students. (p. 11)

Passion in the school environment seems to entail some aspect of radical reform. Rarely does change come calmly and predictably. A quick review of popular educational movies such as Dead Poets Society, Stand and Deliver, Freedom Writers, Lean on Me, and Mr. Holland's Opus, reveals themes of individuals who go against the status quo of tolerating low results in their school buildings and among their staff. These individuals take risks, both personal and professional, have a vision for their students that others have missed, and live out of a value system that places students’ needs above their own personal needs. They also have passion—a character that emanates through each scene, which touches lives, changes systems, and many times produces tears among the 
audience, mine included. Whether it is a math class, music, or English class, or inner city or private school, one theme pervades these intense stories, passion.

Describing the efforts of an Australian middle school principal who was intent on changing the dynamics of her school's curriculum, Tooth (1997) stated:

...these leaders seek to build on and influence values and culture as they open new and creative pathways for change through the mediated use of cultural tools and by staying open and emotionally attuned to the spontaneous self-organizing forces of chaos and complexity within their organization. (p. 1)

\section{Change in School Climate}

How do these leaders affect such lasting change? Three areas stand outcommunication, emotional connections, and visionary action. We communicate with passion and “passionate connections provoke passionate responses” (Bell, 1997, p. 197), so that we receive back in the manner in which we communicate. Passion is vital in leadership and is essential in collaborative management in the school. Great ideas, thoughts, and actions can fall by the wayside if not properly communicated with grace, patience, and conviction. Seminar and workshop notebooks litter the bookshelves of our offices due to a failure to communicate the ideas contained within (Goleman et al., 2002).

Secondly, the ability to develop emotional connections with colleagues and students play a vital role in passionate change. In his groundbreaking book on emotional intelligence, Primal Leadership, Daniel Goleman (2004) listed four domains and associated competencies:

Self Awareness: A deep understanding of one’s emotions, strengths, limitations, values, motives, self reflection, and thoughtfulness; produces motivation and intuition which includes emotional self awareness, accurate self-assessment, and self confidence. 
Self Management: Focused drive needed to achieve goals; frees us from being a prisoner of our feelings; enables transparency and allows for integrity and includes emotional self control, transparency, adaptability, achievement, initiative, and optimism.

Social Awareness: Empathy—aware of others' emotions; ability to express a message that moves others; leader appears approachable; honors diversity and includes empathy, organizational awareness, and service to others.

Relationship Management: Handling other people’s emotions authentically; friendliness with a purpose; resonance with a wide circle of people and includes inspirational leadership, influence, developing others, change catalyst, conflict management, building bonds, and teamwork with collaboration. (p. 39)

So, without useful emotional intelligence, (i.e., the ability to connect effectively with others), a leader's passion takes them nowhere; for people may be educated by reason, but will be motivated by passionate and effective connections (Goleman, 2002). Finally, visionary action leads to passionate change. Passionate leaders have a vision for what their students, schools, or staff may become and are willing to act upon that vision. Their values and beliefs in the curriculum or in the counseling office motivate them to become involved at a level much deeper than those around them, which often causes tension, resentment, and fear. Their techniques often times appear absurd (e.g., standing on a desk and tearing out the introduction to a famed textbook; tender, teaching music to the "un-teachable"; radical, carrying a baseball bat to rid his school of drug dealers; or even dangerous, working in a minority school among gang members and 
actually expecting advanced performance). Derrick Jensen (2004) described visionary action as:

There's something else I wished I had told them, but I did not because the language didn't come to me until later, and that is that I regret my mistakes of timidity more than those of recklessness; actions undone more than actions done. Regrets have never come from following my heart into or out of intimacy, no matter the pain involved, but when, because of fear, I didn't enter or leave when I should have. Regrets have come when fear kept me from my heart. (p. 49)

Passion has the potential to affect major changes in a work environment, family, friendships, church, and school, and is evident to others in any given social context. It produces a calling to teach, to serve, and to go beyond the current expectations. Passion is looking for the messages that tell us to go into strange areas of education (hooks, 1994), many times places we are not comfortable with. It is seizing the opportunity to enter the moment and to share a personal story of faith and who or what inspires you. Passion is guided by love and will seek to help and inspire others unlike myself (Palmer, 2004). To become passionate, forces us to see the need for spirituality and the role it plays in our growth—a "humbling" of sorts (Palmer, 1998, p. 108). Recent research has indicated the need for school counselors to explore spirituality, to understand the implications of the ethical and legal standards, and to employ strategies to support the practice (Lambie, Davis, \& Miller, 2008). Parker Palmer (1998) in his book The Courage to Teach stated that as teachers,

When you love your work that much — and many teachers do - the only way to get out of trouble is to go deeper in. We must enter, not evade, the tangles of teaching so we can understand them better and negotiate them with more grace, not only to guard our own spirits but also to serve our students well. (p. 2) 
Palmer called this our inner landscape, a place in educational reform where we ask not simply the what, when, and why questions, but get down to the who question. Who is the self that counsels? Summing up the power of passion in a leadership role, Bell (1997) explained the result of leaders with passion:

They took the governors off rationalism and prudence, letting their spirit ascent from within. The passion at the heart of every great undertaking comes from the deep longing of human beings to make a difference, to have an impact. It comes from what you contribute, rather than from what you get (p. 197).

\section{Researcher's Experience}

Working in the educational setting requires much more than a personal knowledge of subject matter and the ability to use effective methods to convey said matter. I personally spent four years as a high school biology teacher and remember quite well the emptiness and despair I felt in teaching a subject I knew little about and had even less passion for. The students could smell my despair three classrooms away. They knew it and I knew it, and it drove me to accept this mediocrity or go about finding my true passion in life—counseling. I could not give away that which I did not have. Years later I read a phrase that described my decision to leave the teaching field and enter the counseling field, “The divided life may be endemic, but wholeness is always a choice.

Once I have seen my dividedness, do I continue to live a contradiction, or do I try to bring my inner and outer worlds back into harmony?” (Palmer, 2004, p. 17) Palmer went on to discuss education as being about personal healing and wholeness. It is about empowerment, freedom, transcendence and, about renewing the vivacity of our existence, “a rejoining of role and soul” (Palmer, 2004, p. 10). 


\section{Developing and Maintaining Passion}

The passion at the heart of every great undertaking comes from the deep longing of human beings to make a difference, to have an impact. It comes from what you contribute, rather than from what you get. (Senge, Kleiner, Roberts, Ross, Roth, \& Smith 1999, p. 62)

In a five-year study of successful counselors, Skovholt and Jennings (1992) found that master therapists exhibited several positive growth factors such as:

Growth in cognitive function, which includes wisdom, curiosity, becoming a voracious learner and having a keen understanding of the human condition, proper reflective stance, and a movement from received knowledge toward constructed knowledge.

$>$ Emotional health, which includes acceptance of self, humility, becoming selfaware, an intense will to grow, enjoys life, strong professional individuation development, and professional development that leads to a decline in pervasive anxiety.

$>$ Relational maturity, which enables one to engage others (e.g., peers and supervisors), an ethical compass, welcome openness to life feedback, interpersonal perception, and an open and supportive work environment.

Successful counselors exhibit positive growth factors, which include the areas of learning, peer relationships, overcoming personal challenges, understanding suffering at a profound level, understanding limits and boundaries, knowing the nuances of the therapeutic relationship, ongoing mentoring, and following appropriate ethical behavior (Skovholt \& Jennings, 2004). Paying attention to and developing our inner landscape (Palmer, 1998) are often ignored, and downplayed as of little importance. Busy 
counselors can succumb to the daily challenges and pressures of a school environment and ignore this vital feature of professional lives.

\section{Developing Passion}

How does one develop passion? Parental influence on developing our passion is not surprising, nor is research on familial influence on vocation and leadership new. Csikszentmihalyi, Rathunde, and Whalen (1997) conducted a five-year longitudinal research study designed to answer the question of how young adults become dedicated to the development of their gifts. The research examined an equal number of boys and girls who were nominated by teachers as having high potential and goal clarity in high talent areas. The researchers described talent as having three dimensions: (a) individual personality traits inherited or developed, (b) dependence on the social environments made up of educators who decided whether a certain performance is to be considered talent or not, and (c) the determination of cultural patterns that define certain areas of performance as significant. The results of the first stage of the study showed that students who concentrated on their talents were absorbed in the activities, found time to be alone, had a great deal of contact with parents, limited television, limited their time socializing, and concentrated on school as their main focus. In a second stage, researchers found families that offered support where parents were good role models, practiced intellectualism, and were well disciplined, generally had the greatest impact on highly talented teenagers who were considered to have unique talents and practiced flow of their talents (Csikszentmihalyi et al., 1997).

Energy and flow are engendered by passion (Belitz \& Lundstrom, 1998). Passion is caring deeply about something beyond ourselves, engaging at an intense level, and 
letting go of self preservation to involve ourselves wholeheartedly to something. Others can see this in a context of relationships where one is involved in an intense drive to know the truth and to answer the questions of life. Csikszentmihalyi wrote the seminal work on the concept of flow and described it as "involved in an activity that nothing else seems to matter” (Csikszentmihalyi, 1996, p. 3-4). The experience of flow is so pleasurable that they will do it at a great cost for the sheer sake of doing it, "when a person's body or mind is stretched to its limits in a voluntary effort to accomplish something difficult and worthwhile” (Csikszentmihalyi, 1996, p. 72). Flow can be creative, yet extremely objective as well.

\section{Maintaining Passion}

Maintaining and managing energy, not time, seems to be an effective way to look at high performance and personal renewal (Schwartz \& Loehr, 2005). Understanding, along with rewriting one's personal story, is a key to change. This is in contrast to an emphasis on time management theory, which stresses the ability to multitask, thus removing one's self from the possibility of full engagement. Managing energy includes the following concepts:

Physical energy: nutrition, sleep, exercise; foundation for all energy; can affect the other three: emotional, mental and spiritual; defines that we are.

Emotional energy: impact of our emotions; affects the quality of our stories; how we do things with indifference or intensely; defines how we are.

$>$ The mind: focus, reacting, reflection instead of multitasking; influences the focus of our stories; thinking, logic, and cognition; the alertness, sharpness, fineness of our thoughts, and ideas; self awareness; defines where we are. 
Spiritual energy: what I enjoy, what is important to me, clear sense of purpose, and making a difference in the lives of others; involves the human spirit; intensity of our stories; energy of purpose, values and beliefs; compels us to go beyond ourselves in ways no other energy can; defines the why we are (Schwartz \& Loehr, 2005, pp. 9-11).

These four concepts are strikingly similar to the words of Jesus over 2000 years ago as he emphasized the command to love God with "all your heart, mind, soul, and strength” (The Holy Bible New International Version, 1985).

According to Loehr (2007), the foundation of all energy management is good storytelling and that energy follows our stories; we give life and energy every time we tell a story. If a story elicits energy and passion, success generally follows, and if not what change in the story will do so? Engagement is an acquired skill that allows us to be in the present space and it is in that space where people feel happiest and not experiencing disengagement. Engagement enables us to ignite our talents and skills and these engaged people, called energizers, who are not simply charismatic, entertaining, and intense, but bring themselves fully into an interaction with others. Energizers are not only the top performers and best motivators, but have their ideas accepted more readily (Loehr, 2007). Full presence in an interaction involves hope—-that is, the activity might actually make a difference, that it is worthy, and can be attained. These leaders get excited about the possibilities and are able to not spend valuable energy looking at the failures and pitfalls of a typical life experience. Concepts found in solution focused brief counseling, such as looking toward future possibilities and solutions (Littrell, 1998), and strengths based theory (Buckingham, 2001; 2007) seem to lend credence to this. Every 
one of our thoughts, emotions, and behaviors has an energy consequence, for better or worse.

The skilled management of our energy, not time management, is the key to more productivity, health, and happiness (Schwartz \& Loehr, 2005). Scores of books, videos, and articles have been written about time management and yet recent research seems to mitigate the importance of this as contrasting with energy management and full engagement concepts. In this new approach, multitasking is viewed as the enemy of extraordinariness or living a passionate and energetic life. Full engagement in a particular activity allows life to be enriched because of the commitment, passion, and focus we give it, not the time we give it. Schwartz and Loehr (2005, p. 6) offered two paradigms describing the different ways of approaching the concept of energy (see Table 1).

Table 1

Schwartz and Loehrs' Old and New Paradigm on Energy Old Paradigm N N N N Naradigm

Manage time

Avoid stress

Life is a marathon

Downtime is wasted time

Rewards fuel performance

Self-discipline rules

The power of positive thinking
Manage energy

Seek stress

Life is a series of sprints

Downtime is productive time

Purpose fuels performance

Rituals rule

The power of full engagement 
Four principles guide full engagement. They are:

$>$ Principle \#1 - Full engagement requires drawing on four separate but related sources of energy: physical, emotional, mental, and spiritual.

> Principle \#2 - Because energy capacity diminishes both with overuse and under use, we must balance energy expenditure with intermittent energy renewal.

Principle \#3 - To build capacity, we must push beyond our normal limits, training in the same systematic way that elite athletes do.

Principle \#4 - Positive energy rituals—highly specific routines for managing energy—are the key to full engagement and sustained high performance. A positive ritual is a behavior that becomes automatic over time-fueled by some deeply held value. (Schwartz \& Loehr, 2005, p. 9-15)

Passion and Story

Loehr believes that passion and storytelling are interwoven. He believes that the foundation of all energy management is "good storytelling” (Loehr, 2007, p. 169) and passion follows the stories we tell about ourselves. We give life and energy every time we tell a story. Our subconscious takes up 95\% of our energy and it is difficult to reach and change this. Energy requires a change in our habits and behavior. Creating a new story, and thus new thinking and having it embedded in our consciousness, generally takes about 90 days to accomplish and is vital to developing passion (Loehr, 2007). Engagement is an acquired skill that allows us to be in the present space; it is in that space where people feel happiest and not experiencing disengagement. We have the ability to tell the old story and the new story about us at work, in our family, concerning our health, happiness, and friendships. For most people, writing an old story with several 
drafts of honest assessment may shock and embarrass them; it is vital that one takes the time to do so in order to shake off the shallow ways one views themselves and dig deeper into the reality of their lives. There is many times a shock or awakening that comes with this honest assessment with actual words on paper and then to challenge one's self with a life story that must have purpose and truth; hope filled action will often spur us to take further action to change. Three questions after this time of writing and reflection have proven to be useful:

Will this story take me where I want to go? Looking at your past true values and purposes and reevaluating these will help in answering this question. "A flawed purpose always results in a flawed ending."

$>$ Does this story reflect the truth? Have I been living according to what I know to be truth in my life?

Does this story stimulate me to action? Will this story allow me to make the kinds of changes I desire? (Schwartz \& Loehr, 2005, p. 52)

Schwartz and Loehr (2005) found two exercises to be useful during this rewriting time. First, if we change a story in our mind, then our emotional response changes immediately. Secondly, if we evaluate an action or event fairly, determining its factuality is not enough, we must try to divine its purpose. Also, to keep us from being seduced, we need to work at understanding the why behind the what. After we spend time writing our stories it is useful to look for themes and making sure the story belongs to me. The authors summed up this point by stating, "Individual and collective disasters happen when we don't examine our story to see if it's really ours anymore” (Schwartz \& Loehr, 2005, p. 88-89). 
Energy and passion may be valued by others for less altruistic means. Others want our passion for their own financial or egotistical reasons. Our values, beliefs, and sociohistorical-emotional outlook on life affect our story. Two people can view the same phenomenon or story and have two vastly different takes on it. The authors reminded that "The only reality we know fully comes from the stories we create around our sensory experience...our private voice” (Schwartz \& Loehr, 2005, p. 120). Passion goes beyond any reward and can come from intrinsic motivational factors. In working with CEOs of various companies, Loehr and Schwartz (2003) found success in bringing executives back to their core values and the important facets of life to rediscover passion. They often described energy and passion as the difference between creative and uncreative professionals.

In contrast to our old stories, we now have the opportunity to find new passion through writing a new story. This is the place where listening, seeing, and experiencing my life and career with full force and focus comes into play as we think and plan a new approach to life. It is about how we can harness and manage our energy, not simply managing time. Multitasking is the enemy of extraordinariness. Full engagement results in life that is enriched because of the commitment, passion, and focus we give it, not the time we give it (Schwartz \& Loehr, 2005).

\section{Stress Factors and Burnout over the Span of a Career}

It is the author's observation that most professional counselors seem to be able to muster up energy and passion during periods of time when it is called for and some even appear to have a personality trait that exhibits passion. But for the vast majority of 
counselors, life ebbs and flows between good times and bad, victories and challenges, and passion can seem to wane with these challenges (Baggerly \& Osborn, 2006). Stress factors and burnout can be the downfall of developing and maintaining passion for counselors in the school setting and include such issues as being a novice, personal trauma, client behavior, work environment, and a lack of relationship support (Skovholt \& Jennings, 1992). In this section I will examine a variety of stress factors that may hinder passion and some of the life span issues that accompany them.

Because of life span changes (e.g., marriage, children, illnesses, divorce, death of a parent, changes in peer relationship at work and away from work, change in supervisor), educators may lose touch with their original passion for counseling. These changes produce a sense of disillusionment and despair (Akos \& Scarborough, 2004; Liston, 2004; Noddings, 1992; Palmer, 1998) and counselors can get "stuck along the way” (Henderson et al., 2006, p. 14), which in time can tend to lead to frustration, despair, and counselor burnout.

\section{Stress Factors}

Stress factors for counselors include being a novice, personal trauma, client behavior, work environment, and lack of relationship support. Novice counselorsbetween one and three years in the profession—often display more stress in comparison to those with more experience (Pearlman \& MacIan, 1995). This can be a result of new counselors being over-involved in the counseling process and not receiving enough support from their peers and mentors (Coster \& Schwebel, 1997). Personal trauma is another stress factor that may lead to burnout among school counselors. It is thought that many counselors enter the field as a corrective measure — that is, to work on some 
personal trauma in their childhood history and this seems to affect novice counselors more than veterans. As counselors grow in their expertise and deal more effectively with their issues, these symptoms seem to decrease (Skovholt \& Jennings, 2004).

Thirdly, client behavior seems to affect a counselor's ability to grow and deal with the stresses in the profession. Prochaska (2006) reported that a counselor's optimistic perseverance can be an effective coping strategy to this stressor. The counseling work environment also can be a factor dealing with stress. Increase in paperwork, poor relationships among counselor peers, administrative duties, and a lack of support systems all contribute to a poor work environment and add to stress levels (Skovholt \& Jennings, 1992). Work environments that contain encouragement from peers and support systems to facilitate growth mitigate these negative effects (Adams, Figley, \& Boscarino, 2008).

Finally, vicarious traumatization plays a role as stress factor in the ongoing development of counselors. Post-traumatic stress disorder (PTSD) (American Psychiatric Association, Diagnostic and Statistical Manual [DSM-IV-TR], 2000) has disturbing symptoms that may be the result of either direct or indirect contact with trauma in the lives of clients. PTSD is defined in the DSM-IV-TR (2000) manual as,

The essential feature of post-traumatic stress disorder is the development of characteristic symptoms following exposure to an extreme traumatic stressor involving direct personal experience of an event that involves actual or threatened death or serious injury, or other threat to one's physical integrity; or witnessing an event that involves death, injury, or a threat to the physical integrity of another person; or learning about unexpected or violent death, serious harm, or threat of death or injury experienced by a family member or close associate. (p. 424)

Counselors are exposed on a regular basis to trauma in their clients' lives and this exposure can negatively change the way they view themselves and the world around 
them, at times contributing to burnout. These traumas include divorces, tragic and other deaths, unmet dreams, violent injury, and emotional, sexual, and physical abuse. Again, peer and supervisory support are essential elements in dealing positively with this stressor (Pearlman \& MacIan, 1995).

\section{Life Span Issues}

I included in the guiding question the aspect of passion over the span of a career. Because I included questions about counselors’ life issues through several decades and had retired counselors in the study I felt the need to address life span issues. Traditional life span theory emphasized an approach that included infancy, early childhood, adolescence, professional life from age 21 to 65, retirement, and then a downhill slide until death by an average age of 72 (Sheehy, 1995). Because of medical and technological advances in the past several decades and the findings of recent research, this older view has been modified to include three different adulthoods in which a person will proceed. Psychological and emotional stages are associated with each and include provisional adulthood (ages 18-30); first adulthood (ages 30-45); and second adulthood (ages 45-85), which may be divided into age of mastery (45-65) and age of integrity (65+) (Sheehy, 1995). To ignore the possibilities presented in this model can limit the opportunities one may experience in career and personal life and can result in missing several benefits or rewards of this later adulthood (Bonilla, 2006). The leitmotif of middle age is viewed not as a decline to uselessness and death but as a renewal of the joys and purpose of living. There is a freedom to see not what could go wrong during these transitions into new life but what kinds of new life can be lived. 


\section{CHAPTER 3: METHODOLOGY}

\section{Research Design}

The research design of this study was qualitative, empirical, and inductive in nature. I used a qualitative and phenomenological approach to guide the research. Qualitative research seeks “to study things on their own terms, levels, as a whole” (Shank, 2006, p. 9) and this was a relevant approach considering the nature of such an

intimate, personal, and textured attribute as passion. Qualitative research is a "fluid and flexible” (Richards, 2005, p. 34) type of research, which was important as this study progressed since I was uncertain what I would discover (Shank, 2006). There was little research done in the area of passion in school counseling and I wanted the flexibility to progress in a manner determinate of where the research might lead me (Creswell, 2007; Shank, 2006).

In-depth interviews were the primary source of data collection. The participants were purposefully selected because they had a nuanced, personal, and intimate knowledge of the phenomenon of passion.

\section{Qualitative Approach}

The qualitative methods approach has an emphasis on understanding or illuminating meanings (Hoshmand, 2006) and studying complex, living systems and interrelationships. It is holistic in nature. Qualitative research has a rich history in the 
education realm and in other social sciences (Merriam, 1998). There are several philosophical assumptions regarding a qualitative approach to research. Qualitative research views the nature of reality of evidence (ontology) in that there are multiple realities, that is, it is subjective. Truth is seen by participants and is not absolute. The researcher uses quotes and themes to provide evidence of different perspectives and stays as close to the participants in the field as possible (epistemology). Researchers must "come clean” during the study, acknowledging their role (axiology). The language in a phenomenological study is personal and literary in its form. Qualitative research uses terms such as credibility, transferability, dependability and confirmability, validation, understanding, discovery, and meaning (Creswell, 2007).

The focus of this research was to focus on participants' experiences of passion, which reinforces the researcher's purpose of determining the effects of an individual's passion in school counseling (Creswell, 1994). In formal dissertation databases or reviews of current literature on passion, there was a paucity of scholarly writing on the subject. In searching several dissertations data bases, I found only a handful of results with phenomenology and passion and none containing the terms counselor, phenomenology, and passion. Qualitative research lends itself to the project when "the concept is immature due to a conspicuous lack of theory and previous research” (Creswell, 2007, p. 146). This seemed to be the case with the topic of passion as related to school counselors.

Qualitative researchers normally study a somewhat smaller group of individuals and maintain the individuality of each of these in their analysis, rather than collecting information from large samples (Maxwell, 1998). Qualitative research employs several 
precepts that include being conducted in a natural setting at the site where the participants experience the phenomenon, instead of a lab with sterile conditions. Secondly, researchers are seen as key instruments in the study. Researchers make interpretations of what is seen, heard, and observed and understand that which cannot be separated from their own historical contextual understandings. Thirdly, an inductive analysis approach or a bottom-up study is conducted in which the participants' meanings are valued and considered primary. Qualitative research has an emergent design and uses flexibility during the process so that phases may change or shift as the study progresses. A theoretical lens is used to view the study, including areas such as culture, gender, race, or class differences (Shank, 2006). Finally, a holistic approach is used to develop a complex picture of the problem or issue. This involves reporting multiple perspectives and identifying the many factors involved in the situation (Creswell, 2007). The attribute of passion can best be illuminated via these processes.

An important concept in qualitative research is the post-positive approach, which is a scientific approach to research that emphasizes logically related steps and rigorous methods of data collection and analysis. Another vital concept of qualitative research is social constructivism (i.e., the desire to seek understanding of the world in which they live and work). Social constructivism is complex (Otero, 2003) and is formed through interaction with others, both historically and culturally.

The qualitative researcher strives to employ an advocacy/participatory stance, which seeks an action agenda that leads toward reform to change the lives of the participants and marginalized groups. Also present is a pragmatic approach that has a focus on the outcomes of the research (i.e., what works) and how this type of study can 
change an organization for the better and improve the lives of those involved (Creswell, 2007).

\section{Phenomenology}

I used a phenomenological approach to guide the research in this study. The focus of a phenomenological study is on "exploring how human beings make sense of experience and transform experience into consciousness, both individually and as shared meaning” (Patton, 2001, p. 104). This approach concentrated on the participants' memories, feelings, thoughts, evaluations, and judgments as they make sense of the experience of passion. Phenomenology attempts to illustrate peoples' experiences and the meaning they make of them, not to explain the experience itself (Schwandt, 1997). The aim of phenomenology is to "develop a complete, accurate, clear and articulate description and understanding of a particular human experience or experiential moment—a rich, deep 'snapshot' of an experience that includes qualities at many levels of experience but especially at pre-reflective levels” (Anderson \& Braud, 1998, p. 264).

Phenomenology also assumes that knowledge is socially constructed (Otero, 2003), which is an important feature of this study. School counselors find themselves in a dense social setting, interacting and working with peers, faculty, parents, family structures, and adolescents in an oftentimes exciting, yet stressful environment. The complexity of the human experience in working with school counselors, whose jobs entail a multi-dimensional approach with today’s students, calls for a conceptual framework that caters to the involvement of me as a researcher, having been a school counselor for 17 years. My work as a school counselor presented a challenge for me as 
the researcher regarding my ability to see the phenomena "fresh" without my own bias. The ability to set aside my bias (i.e., bracketing) enabled the researcher to focus on the participants' experiences. While bracketing is important, it cannot be perfectly achieved (Moustakas, 1994).

\section{Sampling and Participant Selection}

The participants for the interviews were selected from public school counselors in the state of Colorado using purposeful sampling. The sampling criteria included exemplary, Colorado, middle and high school counselors who had been in the field for at least fifteen years. Patton (2001) described purposeful sampling as:

...the logic and power of purposeful sampling lies in selecting information rich cases for study in-depth. Information rich cases are those from which one can learn a great deal about issues of central importance to the purpose of the research. (p. 169)

The number of counselors in the study was determined when a point of theoretical saturation (Patton, 2001) began to show dominant themes among the participants. The final number of participants was nine, when saturation was reached and no new themes emerged. The selected participants were pooled from an email sent out to local counseling department leaders, school officials, and through conversations at counseling conferences, staff meetings, and other professional contact. I initially received little response from the emails sent to counselor leaders so I changed my collection methods by attending regional counseling conferences and obtaining names from various lead counselors. This resulted in 10 names. From this list I used peer nominations to obtain my original five interviews. As the semester progressed I continued this procedure to obtain my final four names. 
After the original list was created, I used snowball sampling (Skovholt \& Jennings, 2004), a strategy where well-situated people were asked to identify information rich informants (Patton, 2001). Counselors who were repeatedly named were added to the pool and reliance on the judgment of peers or colleagues regarding the participants under consideration were honored. Peer nomination techniques have been used by a number of social scientists and researchers (e.g., Cole \& White, 1993; Creswell, 2007; Hillerbrand \& Claiborn, 1990) and have been given psychometric support by Anastasi and Urbina (1997) who concluded that peer nomination is a reliable technique in a variety of settings. Anastasi and Urbina stated that "When checked against a variety of practical criteria dependent on interpersonal relations, such ratings usually have been found to have good concurrent and predictive validity” (1997, p. 468). Patton (2001) suggested using extreme case sampling where only those who had been nominated several times were used and that cases were outstanding in some way—a counselor's counselor—a criteria that after a point of redundancy is achieved, where no new names are nominated, the sampling search was stopped.

The focus of the interviews was to ascertain the development and ability to maintain passion during the course of their careers as school counselors. These exemplary counselors were nominated by Denver metro area school administrators, a counselor educator, and lead counselors, because the participants were noted as being passionate, energetic, and enthusiastic throughout their careers. I included retired counselors in the sampling as I wanted to see what a passionate counselor does when the paycheck is no longer a motivation. Also, being retired did not take away anything that occurred during the course of their career. To assist in validity of nominations I checked 
with peers before contacting participants. According to research protocol each counselor must have been in the school counseling profession at least 15 years, met the above criteria, and had to agree to an interview in their office as well as a follow-up interview via email. Eight of the nine interviews were conducted in the counselor's office and one, because of distance, was done via email communication. Six of the nine participants returned the follow-up interview questions. I am not aware why the others did not.

\section{Research Purpose}

The overall purpose of this study was to examine how school counselors develop and maintain passion over the span of their careers. Studying the phenomenon of passion can best be understood not in the moment or as a personality trait, but rather as a refined attribute after years of trials, challenges, and testing.

\section{Data Collection, Interview Guide, and Questions}

The data collection took place during the 2008-2009 academic school year after approval by the Human Research Committee at Colorado State University (CSU). The procedure summary, consent forms, demographic survey, and interview questions are found in Appendixes A-H.

Phenomenological studies typically employ two broad general questions as methods for seeking answers:

1. What have you experienced in terms of the phenomenon?

2. What contexts or situations have typically influenced or affected your experiences of the phenomenon? (Polkinhorne, 1995) 
These two general questions help to structure the proposed interview questions for this study.

I used both a grand tour question and semi-structured, open-ended questions during the interviews. The interview questions were modeled by themes in Shank's (2006) book, Qualitative Research: A Skills Approach. Because passion is a phenomenon that has proven difficult to verbalize (Damasio, 1999; Frijda, 2000), during the interviews I used artifacts from the interviewee's office to elicit phenomenological information. These artifacts or memory boxes (Clandinin \& Connelly, 2000) included such items as photographs, pictures, knick knacks, and other social artifacts, and were used to elicit recollections of significant events, people, and actions. The artifacts helped recollect the “little fragments that have no beginning and no end” (O’Brien, 1991, p. 39) and thus allowed each participant to discuss passion on a deeper, more meaningful level.

As a way to test my research questions and be trained in the interview process, I conducted and recorded a pilot interview with an educator well known for her passion. I was able to interview a math teacher who is well known in the state as an exemplary and passionate teacher; she had won numerous awards at the local and state-wide level. The interview with Phyllis [pseudonym] enabled me to develop my interview questions and practice my interview skills. Several of her responses revealed rich descriptive data on the phenomenon of passion. Some of the final themes in this study began to emerge during this interview. While this data was not included in the findings of the study, it did help to inform the study. This interview was critiqued by my committee members who have used similar methods extensively in their own research studies. I then reviewed their comments and adjusted my interview techniques and questions accordingly. Information 
I gathered was used to assess the appropriate length of the interviews, clarity of the questions, observation skills, and timely interactions. Further interviews were adjusted based upon these results. An interview and follow-up design was selected to achieve “validity through dialogue” (Skovholt \& Ronnestad, 1995, p. 147). The participants reviewed the first transcript before the follow-up interview questions were sent via email to check for accuracy. Caution was taken regarding the busy times of the semesters for counselors and interviews occurred in their offices, except one done via email.

\section{Analysis}

After transcription and re-listening to the interviews, I used NVivo software ( QSR, 2007) to record and retrieve data in the transcriptions. My data analysis comprised an initial sweep through sentences and highlighting significant statements, sentences, or quotes that provided an understanding of how the participants experienced the phenomenon. My initial coding produced 22 codes from the transcripts. Guided by the categorical-content perspective of Lieblich, Tuval-Mashiach, and Zilber (1988), I remained fluid at this point so I would not become fixated on any particular themes. Constant comparative data analysis was used at this stage to begin defining emergent themes. Subsequently, I wrote a textural description along with the context in addition to writing a journal of personal notes during the data collection and analysis phases to assist in this. Case studies were helpful at this point in the analysis. Four themes emerged and were included in the findings and discussion chapter. 
Trustworthiness: Standards of Verification and Evaluation

Credibility and validation were implemented in the project through a variety of

means. In phenomenological studies, validation is grounded and well supported

(Polkinghorne, 1989). Five questions researchers must ask themselves are:

1. Did the interviewer influence the contents of the participants' descriptions in such a way that the descriptions do not truly reflect the participants’ actual experience?

2. Is the transcription accurate and does it convey the meaning of the oral presentation in the interview?

3. In the analysis of the transcriptions, were there conclusions other than those offered by the researcher that could have been derived? Has the researcher identified these alternatives?

4. Is it possible to go from the general structural description to the transcriptions and to account for the specific contents and connections in the original examples of the experience?

5. Is the structural description situation specific, or does it hold in general for the experience in other situations? (Creswell, 2007, p. 57)

Creswell (1994) suggested the term verification instead of validity be used for qualitative research. Non-statistical procedures for trustworthiness included persistent observation, peer review and debriefing, clarification of researcher bias, member checks, rich and thick description, and journaling (Andersen \& Braud, 1998; Creswell, 2007). The grounding of the concepts of the study came from high quality, rich data that were transcribed directly from digitally recorded conversations. The trustworthiness of the study was verified by use of peer review and member checks, which occurred throughout 
the analysis period. Observations and rich data descriptions were recorded in the researcher's notebook for discussion with colleagues. The counselors were interviewed using a semi-structured question protocol that encouraged the subjects to reflect on their experiences.

Field notes describing non-verbal communication, office décor, and body language were made during each interview. A digital recorder captured the interviews and written verbatim narratives were created (Moustakas, 1994). This method of collecting data allowed for validation of the conversations through member checks (Miles \& Huberman, 1994). Member checks were allowed for interviewees to review their conversations in written format and to rule out any misinterpretation of the meaning of what was said (Lincoln \& Guba, 1985). Participants were sent copies of the textural descriptions via email for review and feedback. Lincoln and Guba (1985) stated that this enhances validity: "Who is in a better position to judge whether the categories appropriately reflect their issues and concerns than the people themselves?” (p. 56-57). Textural and structural descriptions were reviewed by the researcher’s doctoral committee. 


\section{CHAPTER 4: FINDINGS}

The findings in this study were derived directly from the narratives of the nine exemplary counselors who participated. Their demographic information is presented below as are their case summaries, and both create a backdrop through which the study's findings may be understood. The interviews capture the counselors' understanding of their ability to develop and maintain passion over the length of a career in school counseling. Four major themes, with several supporting sub themes, emerged throughout the study and will be explained further. I discussed the themes with my dissertation committee as I proceeded with the coding in order to assist in my insight and progress.

\section{Participants}

Of the 9 interviewed counselors, 5 were female and 4 were male. The average age was 56, with the youngest being 47 and the oldest 74; the average time employed as a school counselor was 23 years. Four participants were retired from school counseling. All four were still involved in some aspect of the profession, either as college professors or in school counseling organizations. All nine counselors were Caucasian. Seven held a master’s degree, one an Ed.D., and another a Ph.D.

The average student load for each counselor was 366 students, excluding the support school counselor, who had a student caseload of 16; most worked in a suburban 
setting. I included the retired counselors' student load during their last year in the school setting. Having counseled numerous years, participants had the experiences, challenges in life, and knowledge in the counseling field to allow the researcher to gather the data on the phenomenon of passion that was needed for this study. They referred to their own counseling practices and life experiences to discuss the environments in which they currently or previously had worked and the impact it had on the development and maintenance of passion over the span of each respective career. The researcher used different types of information, (e.g., member checking and committee input), to confirm and validate the insights to passion these participants shared. In keeping with the CSU Human Research Committee protections in the research protocol, all participants are identified by pseudonyms. Tables 2 and 3 display these demographics.

Table 2

Participant, Age, Years Experience in Education, and Highest Degree

\begin{tabular}{lccc}
\hline \multicolumn{1}{c}{ Participant } & Age & $\begin{array}{c}\text { Years Experience } \\
\text { in Education }\end{array}$ & Highest Degree \\
\hline Frank & 74 & 32 & M.Ed. \\
Janet & 61 & 20 & Ed.D. \\
Joan & 57 & 26 & M.Ed. \\
Kelly & 53 & 18 & M.Ed. \\
John & 45 & 20 & M.Ed. \\
Sam & 41 & 15 & M.Ed. \\
Kyle & 58 & 30 & M.Ed. \\
Mary & 61 & 25 & M.Ed. \\
Sue & 55 & 25 & Ph.D. \\
\hline
\end{tabular}


Table 3

School, Level, Current Role, and Student Load

\begin{tabular}{|c|c|c|c|c|}
\hline Participant & School & Level & Current Role & Student Load \\
\hline Frank & Suburban & High School & $\begin{array}{l}\text { Retired-works with state } \\
\text { organizations }\end{array}$ & 350 \\
\hline Janet & Suburban & High School & College Professor & 350 \\
\hline Joan & Suburban & Middle School & Counselor & 300 \\
\hline John & Suburban & Middle School & Counselor & 350 \\
\hline Kelly & Rural & High School & Counselor & 280 \\
\hline Kyle & Rural & Middle School & Counselor & 520 \\
\hline Mary & Suburban & High School & $\begin{array}{l}\text { Building Resource } \\
\text { Teacher }\end{array}$ & 390 \\
\hline Sam & Suburban & Support Center & Counselor & 16 \\
\hline Sue & Suburban & High School & College Professor & 390 \\
\hline
\end{tabular}

Case Summaries

In the following sections are the case summaries of the nine participants.

Participants were interviewed in the fall and spring semester of 2008-2009 in accordance with the approved protocol. All interviews were conducted in the counselors' offices after school hours, except for the interview done via email. Notes were made regarding the physical atmosphere of the counseling centers, counselors' offices, the researcher's thoughts and feelings before, during, and after the interview, and other pertinent information. Each interview included questions about the participant's family of origin, the inner landscape (e.g., spiritual, emotional, and psychological features) leading to passion, the thoughts and perceived meaning of the requested artifact, descriptions of 
passion, relationships that assist passion, times of personal trial and challenge, and words of wisdom.

Each case includes the participant's pseudonym, a representative quote that best captures the interview, demographics, description of the counselor's office, family of origin issues, thoughts about passion, relationships with peers and family, life challenges, the counselor's artifact, words of wisdom, and personal reflections. The interviews were recorded on a digital recorder and downloaded onto the researcher's computer for transcription. The transcripts were reviewed for accuracy and voice inflections before coding began. The researcher employed phenomenological reduction, going from initial coding to axial coding so as to develop themes that will be discussed. The researcher also used techniques such as reading, journaling, and meditation for analysis.

\section{Case 1 - Joan}

[Hope] is probably the one word I believe the most in. There is hope in anything and everything that I do. Whether it is towards kids, towards my own personal life, towards whatever...there's always hope.

Joan is a well known, 57-year-old female veteran middle school counselor in a suburban school district. She has taught in the classroom and counseled at every level for over 25 years and currently coaches her middle school girls’ basketball team. Joan is a lead counselor and has a reputation in her district for leading a strong, friendly, and progressive counseling department. Her office was neatly appointed with pictures, books, games, and inspirational posters. The entrance to the main counseling office had a 1950s soda fountain theme that ran throughout each counselor's office. Joan spoke in animated terms about her upbringing and how her family, especially her sister, influenced her development of passion and continues to do so. Joan often spoke of her relationships in 
the counseling department, how they moved her to action and allowed her to grow as a passionate counselor. She mentioned several times the relationships she has with the parents of her students and she seemed to enjoy being known among her peers in the community as a counselor.

Joan was enthusiastic during the interview and spoke several times about her faith in God and church as a driving force in her passion. I was surprised at the force of her speech at this point and the clarity to which she spoke in describing her faith. She had recently lost her husband to cancer and this event became an important part of our interview as she spoke of her ability to stay passionate during this difficult time. Although she reduced some of her school responsibilities during this time, she stayed passionate about her role as a counselor, even finding new meaning in her job.

Joan's artifact was a picture of her sister who inspires her. This is a crucial relationship in Joan's life and seems to help her maintain passion. Her words of wisdom referred to the need to take on the personal responsibility to develop and maintain passion, as she stated, "I have realized the power that my life, rather they way I choose to live my life, has on my children, my husband, my growing up family, my friends, and my professional relationships." Joan was optimistic and positive; she used the word "hope” several times during the interview.

\section{Case 2 - Mary}

I have always felt like we all are here for a reason, we all have a purpose, and we want to find our purpose. I was created with a lot of energy [laughs], sometimes too much, so I've always tried to focus that in a positive direction. And, let it, in some small way, help somebody else maybe see an opportunity that they can't see. 
Mary is a 61-year-old female who is currently employed as a Building Resource Teacher (BRT) in a suburban high school; she has spent over 20 years as a school counselor. Mary teaches counselor education courses at a local seminary and is well known in her school district as well as in state counseling organizations. Her office was organized with pictures, books, and knick knacks taking a prominent place. Mary spoke about sensitive subjects growing up in her home and how they shaped her passion today. She described her upbringing as a "dysfunctional home life," while at the same time she received support from her father, a pastor. Mary spoke openly and with fervor about her religious faith, often quoting passages from the Bible. She was energetic during the interview and seemed to be anxious to get out of her office to show me the school and various features of the building that she spends so much time working in. Mary spoke openly about challenges in her marriage, her husband having lost their life savings and a job, difficulty with her home life, and how she has maintained her passion during these difficult times. At times during the interview, Mary readily shed tears. She is excited about her new job as a BRT and the ways she is able to use her counseling skills to help new teachers in the building and staff development for the faculty. Mary's artifact was a coffee cup with a quote about the value of helping children. Mary's words of wisdom indicated the need for continual change during a career to maintain passion—-"Change is good...I need to be willing and courageous enough to say, 'I'm going to step outside of the box for a minute.”’ Mary was energetic and displayed considerable enthusiasm during our interview.

Case 3 - Janet

The passion that I have had over the last 20 years...is a response to the calling that I received from my Lord. As a Christian, I believe that we each possess a 
spiritual gift. And as I've been studying those, interesting of late, I have realized that the Lord has blessed me with and given me this gift of counseling and teaching. And, I think because my walk is very, very important, and because I have such a love for my Lord, the passion is just kind of automatic with that...

Janet is a 61-year-old female retired school counselor who is currently teaching master's level counselor education courses in the Denver area. Janet has been retired for four years. She spent close to 40 years in education and over 30 years as a secondary counselor in suburban school districts in three different states. Janet retired in her district amid much notoriety in the state counseling organizations, having been given a rare lifetime achievement honor by a state counseling organization. We conducted the interview in her classroom at a local university as she prepared to teach class. Janet spoke with excitement about her years as a counselor and engaged in personal and emotional features of her career. Janet spoke about being raised in a "strong Lutheran home" with a "strong willed, yet supportive father." She was encouraged by her father to use her "enthusiastic personality” as she considered a career. Janet spoke often about favorite students and the impact she had on their lives. She stressed the innate features of passion in her life - that she has a certain predisposition to being "bubbly." Features of her family of origin allowed her to develop the "gift" of passion. Janet spoke with excitement and was upfront about her Christian faith, that counseling was a "calling from her Lord," and how that helped shape her passion for counseling. She described passion coming "from the heart and that it is an act of love.” She has experienced several difficulties in her family including having a Down's syndrome child as well as older children with mental health challenges. Janet's artifact was a local newspaper article about her retirement from the school counseling profession. Her words of wisdom include the need to nurture one's personal life in order to maintain passion. She said, “A person who’s burnt out with 
counseling, is probably burnt out with life...burnt out with counseling would be

symptomatic, I think, of a much larger issue...I would probably encourage that person to see if they could find some more balance in their life.” Janet spoke fervently about her faith throughout our discussion, became emotional at times and, shamelessly shed tears.

\section{Case 4 - Sue}

Remember your original passions for becoming a school counselor and revisit those. Challenge yourself by trying something entirely new and different in your working style, focus, and goals. Challenge yourself by learning new things in the profession. Decide what energizes you and make that a priority.

Sue is a 55-year-old female retired school counselor who is currently the head of a university counselor education department and is teaching counselor education courses on the west coast. She has been retired for three years. Sue obtained her doctorate in counseling several years ago in Colorado while she worked as a full time counselor in a suburban school district and raised twin children. Sue is well known for her high physical energy levels and her ability to work long hours. As a school counselor she worked primarily in a suburban high school. We communicated several times via email because of the distance. While growing up, Sue was encouraged to develop her talents to prepare for a career in dance. While training as a dancer in her undergraduate work, Sue became convinced that counseling was her opportunity to "make an impact on others." She is only one of two counselors to mention the American School Counselors Association (ASCA) model. Sue spoke profusely about her faith in God and how He has given her a purpose and "mission” in life through counseling. Sue spent quite a bit of her interview speaking about how her passion comes from the opportunities to help kids and the energy she gets from that. She spoke fondly of the mentors who have helped her along the way. 
Sue was reluctant to discuss life challenges, but offered that her faith brought her through difficult times. Her artifact was an inspirational poster of a runner that read, "What It Takes Is All You've Got." Sue explained that this motto summed up her approach to anything she does in life and particularly in counseling. She spoke about her words of wisdom as the ability to have renewal and new challenges as the key to maintaining passion — “ I have never wanted to waste my precious time in life because I have had an innate drive that tells me I need to make a difference in people’s lives. I believe God has me here to do that very thing. I was allowed life and continue to be allowed life-I don't take these gifts lightly.” Sue impressed me as someone who takes seriously the need to stay in physical shape in order to maintain passion in counseling.

\section{Case 5 - Frank}

Get involved in your profession...so many don't and a lot, not all, but a lot of counselors come to work at eight and leave at four and that's it. You know...they don't gain from, or they don't contribute to and I think both are very important...

Frank is a 74-year-old male, retired school counselor who is still active in the counseling profession in the Denver Metro area. He has been retired for 15 years. Frank is well known as an advocate for innovative and sustainable counseling training programs in Colorado and is considered an expert in post-graduate counseling efforts and developing counselor training programs. Frank has been heavily involved in a popular counselor training conference, which is held annually in Colorado. I conducted the interview in his home office, which had numerous awards, pictures of family, and colleagues on the walls and desk. Frank was different from the other counselors I interviewed. He was upfront about his weakness as a counselor in being able to help students with personal and emotional problems. He explained himself as more "old 
school” and was comfortable allowing other counselors to help students with those "Walden...touchy, feely kinds of issues.” He described himself as an average student. He willingly discussed his failures in other areas of life, including flunking out of both a college and the Air Force. Frank spoke little of his upbringing except that they were relatively poor and he worked from an early age. Frank stated that he did not have much spirituality or calling in counseling. Frank was the most involved in counseling organizations in the state and seemed to find his "calling" in this area. He indicated his greatest life challenges were before he entered the counseling field and that the opportunities to develop and change existing programs excited him and kept him going. Frank's artifact was an award he received from a prestigious organization for his work in creating counseling programs. He explained that this exemplifies his passion because it shows that others benefit from his work that is ongoing. Frank's words of wisdom were for counselors to get more involved in programs and organizations that develop the counseling profession—“So, one of the things I say to people is, 'Get involved....I think you have to have a sort of philosophy of what you're going to do and then doing it." He was different than the other interviewees in that he did not see himself as passionate and did not participate in individual counseling in his practice. His passions were in developing programs to assist counselors.

Case 6 - Kyle

Both my wife and I met at an emotional boarding school...and we did our own personal work. We joined that faculty with the understanding that we would not be asking kids to do anything that we would not be doing ourselves. For the first two years that I was at that school, I did my own resolution work; I did my own issue exploration; I did my own personal work to the point of deep emotional release about any issues that I had up until that point... 
Kyle is a 58-year-old male middle school counselor in a rural school district. Kyle spent time as a counselor and teacher at all three levels as well as a wilderness instructor for troubled adolescents in Idaho. He has served as a lead counselor for his school district as well as in a variety of counseling leadership roles at the national level. Kyle has been instrumental in bringing the ASCA model to his district. His office was simple, neat, and functional. Kyle indicated a troubled life growing up and having issues with his father that he has recently resolved, in part due to his diligence in "fixing himself." A central feature of Kyle's interview was that his passion came from his ability to "work on himself" and that if he did not spend the time and energy dealing with his issues then how could he expect his kids to. Kyle spent meaningful time in the woods of Idaho working with troubled kids and this "24-7 experience" shaped much of what he sees as his success today. Kyle spoke about his spirituality differently than the other participants. He described his spirituality as not consisting of religion, yet meaningful just the same. He has spent significant time over the years alone in the wilderness "finding himself" and "getting re-centered."

Kyle's artifact was a geode. He explained that the geode is "normal and rough looking on the outside yet beautiful on the inside.” The geode was given to him by a mentor who kept the other half. Kyle's words of wisdom indicated that counselors must continue to work on their own personal issues in order to develop and maintain passion, “there's usually resolution work... usually journaling that happens with it... lot of quiet time...in particular times where I feel like I need to reground myself, I need to settle myself, it's more, let's find us a camp, let's find us a place to sit. Let's do some serious journaling...'Who am I? What do I really want? And how am I going to get it?’” Kyle 
was by far the most open and vulnerable participant with his personal life. He came across as very authentic and genuine.

Case 7 - Kelly

It would be funny if you interviewed people that worked with me. One of the counselors thinks that I make things happen or whatever. Like, if I need to see kids, they just show up at my door, stuff like that. So, she thinks I have this power...

Kelly is a 53-year-old, female high school counselor in a rural area of northern Colorado. The counseling center at this high school was a welcoming place and I was warmly greeted by people as I waited for the interview. Kelly's office was large and cluttered with a variety of paraphernalia she used in her counseling. Most horizontal surfaces were covered with stacks of paper and Kelly’s phone rang several times during the time we met. Her office seemed to be a depository for several student led projects. One prominent feature was a pile of coats to be given away to a local charity. Kelly spoke of her passion in terms of the ability to help children and to make a difference in their lives. She had the least to say about spirituality and the connection it might make in developing passion, yet she felt like she had a certain "power" that allowed her to help even the most troubled students. Kelly’s artifact was a small statue of a flying pig that symbolized miracles, and a picture of a student who Kelly described as a miracle. Kelly told a powerful story of this student and her role in his life. Kelly's words of wisdom indicated the need to really enjoy the students you work with. She believes that, "without enjoying the work you do with students you can never make it in counseling.” Kelly appeared to be comfortable as a counselor. She spoke at ease of her “counseling personality” and seemed to have a natural way of interacting with others. 
Case 8 - John

My passion is a combination of joy and sadness. Everything comes together to produce a lot of joy and yet it comes to an end and there is a sadness that comes with it. Passion is both, and for me, there's joy and there's sadness.

John was a 45-year-old, male counselor at a suburban middle school. He has been involved in counseling for over 20 years in a variety of counseling roles including rehabilitation counseling, marriage and family therapy, and school counseling. John serves as a department head for his counseling department and teaches evening parenting classes in the district. His office was well appointed with books, pictures with inspirational quotes, a small Zen garden, and other objects for students to play with. Quite noticeable was a hand-made poster on the wall with several students' signatures and quotes such as "You are the best counselor ever" and "Mr. M__ is totally rad.” John seemed to take particular pride in this creation. John had an extensive background in church work, although he is not currently involved in church activities. He spoke frequently and with enthusiasm about his spirituality. He has been a member of a small group of men who have met weekly for nine years to “work on ourselves.” John’s artifact was a picture of his daughter's soccer team he coached several years ago. He explained how it reminded him of the joys and grief one goes through during a passionate endeavor. His words of wisdom indicated that "to remain passionate we have to sometimes ask ourselves how much we take care of ourselves and do something about it.” John appeared somewhat melancholy during the interview, at times unsure of himself. While genuine, he came across sad at times, perhaps most aware of current challenges he faced. Case 9 - Sam

My passion looks like excitement; when I think of excitement I think of faces; kids that I've made a difference with. [Kids] that were messes when they got here and I 
was able to help them regain authenticity, to make them laugh and [be] more whole again.

Sam is a 41-year-old male counselor in a suburban school district. He teaches and counsels 16 students in a support center. The center is a small building where the district sends students who are involved in serious drug addictions or victims of abuse that result in major issues in their normal school setting. Sam's job is heavily tilted toward leading groups, parent meetings, and interactions with legal teams, one-on-one counseling, and some classroom teaching. Sam does not have an office so we met in a conference room. Sam grew up in a "normal family" and did not have any remarkable experiences to speak of as a child. He did spend considerable time in Young Life, a Christian outreach organization as a member and an employee, but has since left organized religion. Sam maintains he is "open to learning about my faith" and occasionally attends local churches. Sam's artifact was a tattoo on each of his wrists that he uses as a teaching tool. The tattoos are the Hebrew words for "becoming" and "struggle", two concepts that he regards as essential to emotional growth (i.e., one must struggle to become). He spoke frequently about laughter and authenticity in counseling. Sam was the most informed about the psychological features of counseling troubled teenagers. Sam's words of wisdom indicated the need "to return to our authentic self and with that self we can recover the passion that first enabled us to work in counseling." Sam impressed me as someone who has taken his own education seriously, a skilled expert in his field, and excellent at individual counseling of troubled adolescents. 


\section{Data Analysis}

Because data was collected in the form of narrative stories, I chose the categorical-content perspective of Lieblich, Tuval-Mashiach, and Zilber (1988) for analysis. This allowed me to highlight portions of the transcribed text and build appropriate categories. After creating 22 free and open codes, I used axial coding to refine the analysis to the four emergent themes that will be discussed. After transcription of the first seven interviews, I analyzed the data using the constant comparative method to refine later interviews. Open coding and axial coding (Strauss \& Corbin, 1990) were used to determine significant themes found within the data. I will discuss the general findings first and then four prominent themes with sub-themes.

\section{General Findings}

As expected, the interviews with each exemplary counselor resulted in rich and textured data concerning the phenomenon of passion. I left each interview energized, motivated, and full of ideas for my profession. I found the counselors excited to be identified as passionate counselors and humbled about the interview experience. All identified the importance of their role in the schools in which they worked and expressed gratitude for the opportunity to serve as educators. Absent from each interview was cynicism, bitterness, and criticalness toward the education field, students, parents, and peers—-negativity which I have found to be common in “faculty lounge conversation.” Most participants spoke in voices that exhibited excitement, energy, and enthusiasm.

\section{Open Codes}

During the open coding phase of analysis I recorded 22 different codes. From these codes I began conducting axial coding, moving up from the data to form emergent 
themes. After extensive reading, journaling, and thought I arrived at four prominent themes, (i.e., humbleness, spirituality/religion, out of the office, and counselor's family). Humbleness was persistent throughout each interview and was revealed in a myriad of ways. The spirituality/religion theme appeared very forcefully in most of the interviews and added rich descriptions of the counselor's passion. Being out of the office was the action verb presented in most interviews and gave life to the work of the counselor. Finally, the counselor's family played a vital role in the development of passion. The remaining codes became sub themes that supported the four prominent themes. The initial codes were:

\begin{tabular}{|lll|}
\hline$>$ Artifacts & $>$ Current & $>$ Parents \\
$>$ Awards & $>$ Faculty & Education \\
$>$ Calling & $>$ Fun & $>$ Passion \\
$>$ Charity & $>$ Kids & From... \\
$>$ Community & $>$ Life & $>$ Religion \\
$>$ Core Values & $>$ Challenges & $>$ Humbleness \\
$>$ Counselor & $>$ Mentors & $>$ Spirituality \\
Education & $>$ Out of the & $>$ Wilderness/ \\
& Office & $>$ Exercise \\
Origin & & \\
& & \\
&
\end{tabular}

Theme \#1: Humbleness

The most prominent theme to surface was humbleness. This theme was subtle and pervasive through all nine interviews to varying degrees. It was communicated in oblique 
ways and not expressed as deliberately as some of the other themes. This self-effacing feature of a counselor's personality came through in several different ways. All of the counselors made a point early in the interview that they were "humbled," "surprised" or “embarrassed" that they were even chosen to be interviewed or that they did not see themselves as exemplary. They indicated that the students they worked with or the school they were a part of was bigger than they were, and that they were simply a piece of the larger picture. Credit was usually deferred to other faculty, one’s family of origin, a mentor, or to their God.

The attribute of humbleness can be described as either:

1) Humility: the quality or condition of being humble; lack of pride; modesty; aware of one's shortcomings, or as 2) Modesty: Having or showing a moderate estimation of one's own talents, abilities or value; unpretentious; lack of vanity (Shorter Oxford English Dictionary on Historical Principles (5 ${ }^{\text {th }}$ ed.), 2002).

Four sub-themes support humbleness: self-denial, counseling in a context, "who gets the credit?”, and humbleness and spirituality.

\section{Self Denial}

Rogerian theory emphasizes the humanistic aspect in counseling (Rogers, 1961). The ability to empathize with a client (i.e., to place yourself in their situation) also allows the counselor to focus in a greater way on the client. Several counselors had seen the need in their lives to think less of themselves and more of their clients, school environment, or their peers in order to maintain passion. There was a "self-denial” aspect to their work in the school setting. For one counselor it was linked to her faith. This was exhibited in working beyond the normal work day or conducting home visits and other ways of doing more than expected. 
Faith and passion... When I think less of me and my problems and how to make it better for someone else, I am comforted. (Mary)

Another participant said,

Well, I don't take it personally. It's not about me. I could be the best or the worst counselor in the world; it's about...does it meet the need that kid has right now? Is it helping them be a better person? Is it helping them grow? (Kelly)

\section{Counseling in a Context}

The importance of humbleness appeared in the context of the larger picture of the school environment and the overall goals for student advancement. Counselors were reticent to speak about any accomplishments or awards they had received and were generally embarrassed that they had been chosen for the interview. Often they would speak of colleagues or other faculty members instead of themselves. Many times the students they served became the focus of the interview and the importance of their education being paramount, not the accomplishments of the participants. A counselor summed it up by saying,

Yeah...humble, because you know, I don't just think I'm doing rocket science in here, I don't just think I'm creating these incredible people, but I get the feedback that I am, and it just seems so natural and so this is what I'm supposed to be doing, and so I should be getting those kind of results. (Janet)

\section{Who Gets the Credit?}

Most counselors repeatedly gave credit to others during the interview. Mentors in their lives played a large role in their development of passion. There was humility about the good fortunes and successes that came in the counselor's life and some of the struggles her clients were going through. In Alcoholics Anonymous circles this is called, “But for the grace of God go I.” This appeared for those counselors who had experienced trauma in their own upbringing; they were particularly able to appreciate their place in 
life as a helper and as having the ability to overcome life's challenges. A counselor shared,

Well, I just think that the main thing is that we as humans...we're here for a higher purpose...It's not about me; it's not about making money or making a name for myself. Ronald Reagan said, 'If you don't care who gets the credit, you can do great things.' And, that's kind of how I look at it. If you don't care who gets the credit, things can happen, and you can be awesome. But, if you need the credit, you're probably not going to go out on that limb, and you're probably not going to be as big of a risk taker because you're going to want to make sure you get the glory. (Kelly)

\section{Humbleness and Spirituality}

Humbleness was linked with spirituality in several interviews. Counselors stated that the Bible or the church they attend teaches humility as a central feature of their practice of religion. These counselors believed in something higher, more powerful, wiser, and more important than themselves, thus the role of humbleness was directly linked to spirituality.

I never come in and say, "I've got the answer for you...or, I'm going to fix you, and I'm in control. You need to listen to me.” That thought never crosses my mind. I have passion, compassion as well as passion. I say, "Okay, Lord, give me some insight, because I'm not getting any insight into them," and it's amazing when you're looking at it from that perspective, how all of the sudden you can have insight, or you can have discernment. (Mary)

Another counselor stated,

I just really started praying for them. I prayed that God would give me a love for them. I just kept praying that even though I really hated them (laughs). After a while I loved them, and I began to see kids totally different. I began to see them with a love and tenderness and compassion of, "Whoa, this is a person." I think that the bottom line is that I usually don't go into any situation thinking about myself. (Janet) 
Theme \#2: Spirituality/Religion

A second prominent theme to emerge from these interviews was that of spirituality and religion. This theme appeared abruptly in most of the interviews. I was surprised at the veracity of the participants as they discussed this oftentimes private topic. Several participants expressed their spirituality in the form of organized religion, and one with nature and therapy as his preferred practice. Spirituality was the first item mentioned by the participants in most interviews when asked about where passion comes from. All of the interviewees who discussed religion had been raised in a religious home. While it was not always a positive experience, it did seem to influence their passion in significant ways. Most of the participants who discussed the spirituality/religious theme described their passion as a result of their faith.

Spirituality can be defined as "the animating or vital principle held to give life” (Shorter Oxford English Dictionary on Historical Principles (5 ${ }^{\text {th }}$ ed.), 2002). Spirituality attempts to answer some of life's most profound and basic questions such as: Why am I here? What is my purpose in life? What gives my life meaning? (Kessler, 2007) While spirituality is not simply religion, spirituality may be expressed through a particular religious practice. Neither is spirituality reduced to a system of moral choices although they are closely connected (Lantieri, 2001). The participants defined religion in a more traditional language to explain their spiritual relationship to passion. They used biblical terms, (e.g., my Lord, my faith, gifts, service, humility, and love); they talked of church experiences, (e.g., raised in religious home, current church classes, and friends that are 
church members); and they spoke of Christian concepts, (e.g., love from God, command to serve others, hope in the afterlife, and the power of miracles).

Spirituality and religion were expressed with the following subthemes: a spiritual relationship, a spiritual calling, a spiritual purpose, spiritual gifts, spirituality as a help during challenging times, spiritual upbringing, and non-religious spirituality.

\section{A Spiritual Relationship}

Some counselors described their spirituality as a relationship with Jesus. They seemed to pattern their life and professional practice after the example they saw in Jesus' life. These counselors expressed a belief that Jesus was the model counselor and that if they could become more like him, their counseling would likely improve. One participant had written an essay in college on Jesus as a counselor. She described it as such:

I think I have a higher purpose for what I do. Because I have a very close relationship with Jesus and I believe that He came to help, to serve, to heal, and so that's one of the things that I do. And that kind of keeps me going. In fact, at grad school, at a secular school, I wrote a paper on counseling theory, and we could base it on whatever we wanted to base it on - and I wrote mine based on scriptures, and how Jesus was a counselor, and how you could tie that into counseling. (Mary)

Another counselor expressed how Jesus had influenced her as a counselor:

Jesus came to serve....if you look at the Scriptures...they do not talk about that He came to do anything for Himself...He stepped out of Heaven and came down to earth to be a human. He came to serve and to show what true love looked like. I look at loving your neighbor...because the true essence of it is that you really are doing it because you care. You care, you love the person, and you're trying truly to show the love that God has for them. (Janet)

\section{A Spiritual Calling}

A perceived calling in one’s profession can lead to greater meaningfulness, contentment, and job-related efficiency (Csikszentmihalyi et al., 2001). About half of the religious participants indicated that counseling was a calling for them—-that is, they did 
not decide to become a school counselor, but that they were called to the profession from a higher being. This calling was usually sensed after the fact, years later. Absent in all participants' comments was an emphasis on salary or job descriptions.

One counselor shared,

I've read Warren's book, The Purpose Driven Life, and found out that these two gifts are definitely what I've been called to do. I've been trained in them, I'm passionate about them... and all these things I've been reading fulfill what I've read in Scripture. (Janet)

Another counselor stated it this way:

That's why I have the Cross on...it never made sense to me before, but now as I get older, I mean I really believe in the Lord. It makes sense about people talking about a calling; they talk about that you were chosen to do something...This is what I was supposed to do. (Joan)

\section{A Spiritual Purpose}

In addition to a spiritual calling, counseling seemed to give participants a sense of spirituality in that it allowed them to make a constructive mark on their students, peers, and schools (Rockwall, 2002). Several of the interviewees spoke about the purpose and satisfaction they find in counseling others. One counselor became emotional as we discussed her purpose in counseling. As she enters retirement she thinks often about her purpose and how she can continue fulfilling her purpose during her retirement. This purpose was reflected in the hours that these counselors kept. Many of them were the first in the office and the last out in the afternoon. They tended to be more involved than their peers with clubs, sports teams, and other extracurricular activities.

...this cup says that, "For the love of children, embrace, and nurture the spirit of each child.” I just, I really love that, and I think every child is created unique, and they have something to offer. And I have always felt like we all are here for a reason, we all have a purpose, and we want to find our purpose... and let it, in some small way, help somebody else maybe see an opportunity that wasn't, that they can't see. (Mary) 
Another counselor expressed:

I have a strong support system in my life that helps. I have a strong faith in God. I believe I am here on this earth for a purpose, and that purpose changes as I get older....Well, I think that is the heart of who I am, and, as you go through life, you make a choice, Why am I here? And, you have to discover that for yourself. (Janet)

\section{Spiritual Gifts}

Research indicated that those who concentrated on their gifts and talents were able to express their passion in meaningful ways (Csikszentmihalyi et al., 1997). A few counselors saw their counseling abilities as a "gift" from God and for them to not use this gift would have been to deny their calling in life. Some participants described gifts as talents that were given to somebody and while not "earned" must be developed and nurtured in order to be useful. Counselors used this gift by praying for their students, applying biblical concepts to counseling, and having a vision for change in even the most difficult cases. Counselors spoke of their gifts as personality features they were born with or developed in their youth. Some were "junior counselors" growing up as they found themselves helping friends with issues. Counseling seemed to be a "good fit" and natural for these counselors.

I think, first of all, the passion that I have had over the last 20 years... I think it is a response to the calling that I received from my Lord. As a Christian, I believe that we each possess a spiritual gift...the Lord has blessed me with and given me this gift of counseling and teaching...because I have such a love for my Lord, the passion is just kind of automatic with that... when I think about working with kids, or working with someone in a counseling situation that energy and enthusiasm to empower someone else just kind of automatically flows out of me. And, I believe that is a gift from the Lord. (Janet)

\section{Spirituality as a Help during Challenging Times}

As expected, those who relied on their faith in the development of their passion also relied on it as a help during times of challenge. Not only did their faith sustain them 
during these times, it allowed the counselor to grow and find new meaning in their careers. Challenges ranged from burnout, raising children, full time employment, lost jobs, divorce, mentally challenged children, and the death of a spouse. All of the counselors were able to keep their careers intact during difficult times. While the interviews many times produced tears, even in speaking about the death of a spouse, the conversation was generally positive and meaningful. I found it remarkable that no one spoke of life's challenges with any bitterness or resentment toward God, family members, colleagues, or even the perceived source of the challenge.

I believe I have a strong inner core. I do get upset, discouraged, and saddened through difficult times, but I don’t remain there. I have always bounced back. (Kyle)

Another counselor said,

January 2004 we get the diagnosis: cancer, three months to live. I continued working, even though I was told to stop. You've got me. You've taken away my best friend, my husband, my everything. So now, what are you [God] going to do? What do you want me to do because I'll do it. And ... that's where my driving passion is. (Joan)

\section{Non-Religious Spirituality}

Others experienced their spirituality from a non-religious background, speaking in terms of their inner core beliefs or their value system. These included time outdoors, journaling, therapy work, or deep and meaningful relationships. Nevertheless, the effect was similar to those of a religious persuasion. Spirituality seemed to be the primary force that guided their passion.

I tend toward more of the meditative practice. I find a lot of spirituality in the wilderness; a lot of personal work has taken place for me in the wilderness... there's usually resolution work that happens with it, there's usually journaling that happens with it... a lot of quiet time. In particular times where I feel like I need to re-ground myself, I need to settle myself...Let’s find our self a camp, let's find our self a place to sit. Let’s do some serious journaling. (Kyle) 
Another stated,

I'm a member of an informal, men's support group which has met every Friday for the past nine years. We come from all kinds of backgrounds and we work on all our inner stuff together. (John)

\section{Theme \#3: Out of the Office}

A third major theme to emerge from most of the interviews was that of counseling outside of the office or as it is referred to in business books, managing by walking around (Peters \& Austin, 1985). Counselor's duties included substantial amounts of paperwork or other clerical duties such as testing, programming, scheduling, and answering emails (Bemak, 2000). There was always plenty to do in the office and yet passionate counselors spent copious amounts of time outside of their office in the hallways, cafeteria, classrooms, gymnasium, after school hours in the community, and extra-curricular activities with their students. The sub-themes of physical appearances and location of the counseling office, getting work done outside the office, synergetic relationship, relationships with the faculty, and work outside the building, are discussed.

\section{Physical Appearances and Location of Offices}

Almost all of the counselors put obvious efforts in the neatness and atmosphere of their offices. Offices were neatly appointed with books, inspirational posters and pictures, age-appropriate knick knacks, (e.g., stress balls and Zen gardens that students could play with, and comfortable chairs). The reception areas reflected this inviting environment. One counselor was dismayed at the location of her counseling office during construction of a new school. She commented,

And I thought, Great! [sarcastic] Now, when we were building, when we were at (local high school) and we had our counseling offices right off the hallway. 
She continued,

Well, did you see the front? You saw the 50s theme and all that. We want to make it decorative, real fun that way. We're out in the hallways all the time. You know that was the design flaw of this building. I said, "Oh my god, we're in the back of the bowels of the building.” They said, "Well, yeah, you get a window.” (Joan)

Another counselor added,

I just want kids to feel like this is a place [his office] where they see other kids have been to and they too can come here to talk...it is a cool place. (John)

\section{Getting Work Done Outside the Office}

Because school counseling occurs in a rich social context, most counselors I

spoke with found the need to be visible to the faculty and student body and spent considerable time outside their offices. This enabled them to accomplish several tasks, including observing how the students acted in their "real world" environment, and allowing the counselors to create connections with both the student body and faculty. Some counselors spent time in the cafeteria during lunches and others spent time in the classrooms teaching. Others stayed in the hallways during passing periods. Rather than seen as a bothersome duty, these counselors looked forward to "getting out there."

You get out of the office... and you get out there. I'm out there every day at lunch. Not only because I have to be, but because I want to be out there. You can see the dynamics of the kids; you get to see who they're with, what kind of day they're having. You get out there, you walk the halls; you're out there with the kids... you're meeting with your teachers. You just make yourself as visible as you possibly can. (Janet)

Another counselor said,

Because I get to teach, I get to teach a lot...whenever I want to, there's always somebody I can go into their classroom and teach creative lessons. (Joan) 


\section{Synergetic Relationship}

Counselors spoke about the fact that getting out of their offices allowed them to experience more energy and job satisfaction by being around the students. It was not just what students or faculty gained from this experience but the counselors benefitted as well. This seemed to provide energy and became fun for the counselor and became a synergetic relationship. The more time they spent outside their offices with kids, the better and more effective counselor they thought they became. Thus, counselors developed a desire to spend more time with the students and faculty. This motivated the counselors to spend even more time outside their offices.

So when I spend time in the hallways or classroom it makes it so kids aren't so scary. It helps me to want to be a better counselor. (John)

Another counselor added,

We're not just these old counselors sitting in the back corner. We do coaching, we do activities, and we're always trying to come up with new ideas. Coaching definitely feeds the passion just because I get to go play with kids. (Joan)

\section{Relationship with Faculty}

Relationships between school counselors and faculty traditionally have been sources of confusion and often resentment. Teachers may not understand the roles of counselors and what they do, which may lead to frustration when counselors call students out of the classroom for individual counseling or group work. Being outside of the office has allowed counselors to promote themselves and be living and breathing examples of their job descriptions, thus an asset to their school environment.

I always get out of my office and I walk down to that teacher. I've never sent an email or a note to a teacher and said, come see me. I think because counselors have an office, they set themselves apart anyway, and then teachers begin to think, "Well, who do you think you are? You just sit in your office."...So, I always stop what I'm doing for a teacher, as well as a kid. But, I think because 
you have an office and a phone, and you don't have kids every period, that right there is a barrier. So, what I found early on is that I would leave my sanctum [laughs] and I would go to them-it's just amazing what that does...I will walk clear out - we have mobiles, we have the UCC [nearby building] we have classes in - I'll walk all the way out there and say, Hey, have you got a second? And, they're like, Oh. So that has broken that barrier down, I think, for me. (Mary)

Another counselor said,

Hey, hang out in the halls with them, just go in. You know, just things to say, I'm one of them, because you're not and they know it, and that was a shock to me when I became a counselor from a teacher. So, I can say, Okay, I can eliminate part of that by going out there and being a part of them. (Joan)

\section{Outside the Building}

Some counselors lead or supported activities outside the regular school day. This

included coaching a basketball team in the middle school, club activities, field trips, a variety of positions on counseling organizations, and overnight camping trips with a counseling component built in.

Yeah, but I would go do different things with kids and sponsor kids or go on field trips, or let teachers know, hey, if you have a field trip, I'll go on it with you...I would do things over and above...to try and be connected with the life of the school because you can just get stuck in the rut of, the certain kids you see and the credit checks and all that, and you just have to really, truly make a conscious decision to not do that. (Kyle)

Another participant shared,

Well, I think every school has a heartbeat, and has its own personality. And, counselors can add to that and really bring a lot of rich and important information to a school. Or, they can really just be their own kind of little entity over here. And, that's not a healthy thing. And, I think teachers get resentful because they don't know what we do. And, they begin to think that we think...that we're just here...we come in, we leave early... all the things that go around that. And, so, I've tried to go to activities, or sponsor things, or be with kids, or just be involved in what the teachers were doing. I would just volunteer to do things for them. (Mary) 


\section{Theme \#4: Counselor’s Family}

Finally, the counselor's family theme emerged as a consistent and prominent theme in these interviews. Both the participant's family of origin and current family features were discussed after being asked about their family of origin. All participants were quite descriptive when asked about their families and a few became emotional during this part of the interview. Both positive and negative features were shared. The counselor's family of origin played a significant role in the development of passion. Experiences of being raised in a religious home, having a home life that promoted charity, raising one's own children, educational expectations, and self-esteem issues were discussed.

\section{Raised in a Religious Home}

As participants were asked about their family of origin, most indicated that they were raised in a religious home. These were all of the Christian faith and contained both positive and negative experiences. The positive experiences included such features as two parent structure, spiritual instruction, discipline about education, and reasonably high expectations. The negative aspects included verbal and emotional abuse and an unhealthy emphasis on dogma.

I was brought up Lutheran, interesting enough, because it was pretty strict, but it had a very strong Biblical foundation to it...I think many of us become stronger in our belief systems as we grow older. Mine has definitely strengthened in the last four or five years. I will say that that is because I now have the time, as a retired person, to read my Bible, as much as possible, daily, to pray more often, to ponder and discern, what I'm reading. And, begin to apply all of those things that I learned from when I was a little tiny kid. And, now I'm watching the fulfillment of those things actually happen in my life. (Janet)

Another counselor added, 
And, I was not raised in a functional family. I was raised in a very abusive home. So that's probably one of the reasons I went into counseling, because I wanted to help kids...I didn't realize that there were a lot of horrible things that kids live through. (Sue)

\section{Charity}

Being raised in a home where the culture involved sacrifice, charity, and a spirit of giving seemed to play a role in the counselor's passion. These experiences include being foster parents, adoptive children, helping the homeless, and other acts of giving that seemed to go beyond the norm. Many interviewees came to believe this was an expectation for them as they grew up, and some felt this was an important feature of their choosing counseling as a profession.

I do know another influence: my parents — that's probably why I ended up in this kind of role-my parents were very generous people in the community, lots of people stayed with us throughout the years... So it was very much a kind of take care of people responsibility, but they didn’t say it, they showed it. (Kelly)

A participant said,

I can say a lot of, in my home, my parents did a lot of helping and caretaking... and I just saw that as_-and I was very interesting in psychology. (Sue)

\section{Children of Their Own}

The participants shared how going through typical and atypical experiences in raising their own children allowed them to understand better the challenges families go through, which produced more empathy. To have children of their own seemed to help counselors to be more compassionate and passionate. Also, having personal experiences with trauma as a child, or growing up in a difficult environment allowed the counselor to better relate to and develop empathy with students and thus experience success in early counseling. One counselor shared, 
I think having my own children made me a better teacher. Before I had kids, I was not as compassionate, maybe, as I should have been... as to their role in their family... and what their priorities were. (Joan)

Another counselor said,

Well, one thing I did was, I found a milestone on the highway... whatever or wherever I worked, I found a place on the side of the road and every single day, when I got there, I dumped it [negative issues from the workday], and I left it, and I never talked about it at home. I had three kids to raise, and I did not want them to hear what was going on, and I did not want them to get a skewed view of life. (Mary)

\section{Education Expectations}

Educational expectations became a common thread in comments about family of origin. None of the counselors had a parent who was a professional counselor and only a couple had parents who worked in education. Most counselors had parents that emphasized the importance of education from their earliest memories.

My father, he had...much passion for education. He pushed pretty hard to get an education, but he didn't make me do anything... I did not know what I wanted to do. I was pretty good at math and science in high school. I was not a great student. A pretty average student; a pretty average athlete... (John)

Another stated,

He [Dad] used to always push that pretty hard. He said, you know, you've got to get an education...you've got to go to college. (Janet)

\section{Self-Esteem Issues}

Several counselors indicated that regardless if they were raised with positive or negative family dynamics, they were brought up with a message of positive personal selfesteem. This message was communicated to them emphatically and seemed to allow them the opportunity to follow their dreams in pursuing education and ultimately their work in counseling. While counselors shared about positive and negative aspects of their 
family of origin, the most powerful descriptions involved the negative aspects and how that enabled them to find passion in counseling.

I didn't know before I went out into the world that my family was very functional by most family standards. So, although, a lot of the people I met in my master's degree program seemed to have issues they wanted to resolve-you've seen that, too, I'm sure. I didn't come from that. Our family communicates well, humor...I was the oldest; my parents told me I could do anything I wanted and do it well. And, so, I did. I was very independent headed. (Kelly)

Another counselor stated,

You know, there's the good in everybody, and you are going find it. And, I look at these little kids and they're twelve years old. And, instead of, in spite of what has happened because of their parents, they're going do it, they're going make it. (Joan)

Table 4 lists the participants by the four prominent themes they discussed: 
Table 4

Passion Theme by Participant

\begin{tabular}{|c|c|c|c|c|}
\hline Participant & Humbleness & Spirituality & $\begin{array}{c}\text { Out of the } \\
\text { Office }\end{array}$ & Family \\
\hline Frank & $\mathrm{X}$ & & & $\mathrm{X}$ \\
\hline Janet & $X$ & $\mathrm{X}$ & & $\mathrm{X}$ \\
\hline Joan & $X$ & $\mathrm{X}$ & $\mathrm{X}$ & $\mathrm{X}$ \\
\hline John & $\mathrm{X}$ & $\mathrm{X}$ & $\mathrm{X}$ & $X$ \\
\hline Kelly & $X$ & & $X$ & $X$ \\
\hline Kyle & $\mathrm{X}$ & $\mathrm{X}$ & $\mathrm{X}$ & $\mathrm{X}$ \\
\hline Mary & $X$ & $X$ & $X$ & $X$ \\
\hline Sam & $\mathrm{X}$ & $\mathrm{X}$ & $\mathrm{X}$ & $\mathrm{X}$ \\
\hline Sue & $\mathrm{X}$ & $\mathrm{X}$ & $\mathrm{X}$ & \\
\hline
\end{tabular}

Words of Wisdom

Each interviewee was asked at the end of the interview, "What words of wisdom would you tell a burned out counselor about regaining their passion?” The answers to this question varied among all participants. A couple of counselors spoke about the need to find earlier passions and return to those, stating,

Remember your original passions for becoming a school counselor and revisit those. Challenge yourself by trying something entirely new/different in your working style, focus, and goals. Challenge yourself by learning new things in the profession. Decide what energizes you and make that a priority. (Joan) 
A few counselors indicated that burnout reveals the need to find other kinds of work, both in and out of the education field. One counselor was quite blunt in his assessment of burnout saying they should "just get out," while others spoke about the need to reassess their situation,

Find something different then. Do something else for a while because you have to rebuild that passion and you have to rebuild that love for the kids. And, if you're at a point—and this may sound, I mean, I'm very pragmatic — you know, if you're at a point that you can't do this right now, that's okay. That does not mean that you're a failure. It doesn't mean that your life is over. It doesn't mean that you can't come back to this. It just means, maybe you do need a break to get perspective. (John)

Another counselor added,

Now I understand that more because they're hanging' in there for the rest of their retirement and their building in hours so that you just say, Oh, get out and go find something else. (Sam)

Finally, other counselors indicated the need to take care of themselves to prevent burnout.

Remember, even with your best efforts, some youth will not change. Take care of yourself. Don't let your career consume you-you have other parts of your life that are so important. (John)

\section{Artifacts}

All participants were asked a week in advance of the interview to do two things.

First, to simply be thinking about their own personal passion and secondly, to choose an artifact from their office that illustrates their passion (see Appendix C). All the counselors readily shared about their artifact and the meanings behind their choice. The artifacts served two functions. First, their selection allowed counselors the time to think about passion one week before the interviews. Secondly, this allowed the researcher to find rich descriptions about the attribute of passion. The artifacts generally fell into three categories. 
1. Pictures and a geode that reminded the counselor of important relationships. Two participants chose artifacts that were pictures of family and former students. One was a geode that was a gift from a mentor. Counselors seemed to use these artifacts to both reminisce about former students or relatives and to tell stories about positive conversations and events in their lives, which continued to inspire them.

2. Inspirational quotes. One chose a poster, one tattoos, and one a coffee mug with quotes regarding the importance of passion in education. While these quotes were not original, they offered poignant themes for the counselors to access on a daily if not hourly basis. The posters and tattoos served the purpose of a teaching tool for the students in the offices, or in the case of the tattoos, when the counselor spoke to them.

3. Reminders: Awards, newspaper article, and figurine. These reminded the counselor of the importance their career offered. The award and newspaper article were for retired counselors and seemed to remind them of what they had accomplished in their careers. The figurine (a flying pig) reminded the counselor that miracles can happen.

Table 5 lists each counselor with their artifact, the counselor's perceived meaning, and a quote of each artifact. 
Table 5

Participants’ Artifacts, Perceived Meaning, and Quote

\begin{tabular}{|c|c|c|}
\hline NAME & ARTIFACT & PERCEIVED MEANING/QUOTE \\
\hline Frank & Awards & $\begin{array}{l}\text { A reminder that a counselor's work makes a } \\
\text { difference: “to be recognized by your peers, to me, is } \\
\text { about as good a reward as you can get." }\end{array}$ \\
\hline Janet & Newspaper article & $\begin{array}{l}\text { Importance of making a difference: “it was just the } \\
\text { last thing that I had, that said, 'You know, you've } \\
\text { done a good job.'” }\end{array}$ \\
\hline Joan & Picture of sister & $\begin{array}{l}\text { Example of passion and importance of family: “I } \\
\text { don't give up. I don't give up on a kid. I don't give } \\
\text { up on anybody. I was taught that. I was valued and } \\
\text { modeled that by my family...” }\end{array}$ \\
\hline John & $\begin{array}{l}\text { Picture of kids’ } \\
\text { soccer team }\end{array}$ & $\begin{array}{l}\text { What can happen when everything lines up-that is } \\
\text { experiencing the joys and pains of counseling: } \\
\text { "Passion is both the pain and the joys...I have } \\
\text { both." }\end{array}$ \\
\hline Kelly & Flying pig figurine & $\begin{array}{l}\text { Miracles can happen: “I've seen a lot of miraculous, } \\
\text { amazing things happen, like pigs flying. It reminds } \\
\text { me that amazing things happen." }\end{array}$ \\
\hline Kyle & Geode & $\begin{array}{l}\text { The need for mentors in the development of passion: } \\
\text { "to me, represents the fact that a geode, which is } \\
\text { pretty ugly on the outside...you'd walk right over it if } \\
\text { you weren't paying attention, you crack it open on } \\
\text { the inside and there's something really unique and } \\
\text { something really beautiful about it." }\end{array}$ \\
\hline Mary & Quote on coffee cup & $\begin{array}{l}\text { Reminder of reason she works in education-kids: “I } \\
\text { just, I really love that, and I think every child is } \\
\text { created unique, and they have something to offer." }\end{array}$ \\
\hline Sam & $\begin{array}{l}\text { Tattoos on wrists } \\
\text { (Hebrew words for } \\
\text { struggle/ become) }\end{array}$ & $\begin{array}{l}\text { The need to struggle to become: "I tell kids, 'we have } \\
\text { to struggle to become' I show them my wrists." }\end{array}$ \\
\hline Sue & Poster & $\begin{array}{l}\text { Importance of taking care of self: “Take care of } \\
\text { yourself. Don't let your career consume you...you } \\
\text { have other parts of your life that are so important." }\end{array}$ \\
\hline
\end{tabular}




\section{The Passionate School Counselor}

Carl Rogers (1961) described a few essential attributes of an effective counselor. These include the ability to express genuineness, convey empathy, and exhibit authenticity. My personal experiences in locating, communicating with, and interviewing these counselors have been amazing and inspiring. I found each of the counselors to be eager to set up the interviews; they allowed as much time as needed to speak about their experiences. They all appeared genuine and authentic in their responses and seemed to be caring people. This was evidenced in:

$>$ Several counselors shed tears when speaking about their experiences—not tears of bitterness or anger but tears of gratitude and passion.

$>$ Obvious lack of cynicism and complaining.

Stories of caring interactions abounded.

Dialogue was spirited, natural, and enthusiastic.

$>$ Office décor reflected a student-centered and positive environment.

Interviews took place after regular school hours when counselors could have chosen to decline the extra time spent.

I left every interview with a renewed vision for my job as a counselor and with new ideas on becoming a better, more passionate one. I felt pride and encouragement for the profession I’ve worked in for much of my adult life.

In general the interviewees needed little prodding to talk about their passion. I believe allowing them time to think about their passion, that is, each participant was 
emailed at least one week before each interview, and asking them to select an artifact to describe their passion, led to this. 


\section{CHAPTER 5: DISCUSSION}

Several important concepts were revealed in this study that may assist in understanding the various features underlying how school counselors develop and maintain passion. Many of the findings may be linked back to this study, research previously done, and theories explored in the literature review chapter. In this chapter I will review my findings, present a theory on the development and maintenance of passion, discuss the link between the results of this research project and the existing literature, discuss passionate counselors and burnout prevention, share personal reflections, make research recommendations, present research limitations, and offer considerations for further research.

\section{Review of Findings}

After conducting nine interviews and follow-ups, and completing the transcriptions, I employed coding techniques that led me to reduce 22 original codes to four emergent themes. After coding, journaling, thinking, and consulting with other counseling professionals, the following themes emerged from this study of passionate counselors.

The attribute of humbleness appeared pervasively throughout the interviews. It was explained by how counselors viewed themselves, their role in the school environment, their ability to work with students, parents, administrators, and peers, and 
how they defined their success. Humbleness allowed counselors to expend energy without experiencing burnout and permitted them to see themselves a relatively small, yet important element of a larger milieu in the school setting. When given the chance to accept credit for the successes they enjoyed, the humble counselors deflected the credit on others, including colleagues, family, their students, and God.

This humbleness allowed the counselors to keep a perspective on their work in the school. Passionate counselors did not get involved in negative aspects of school culture, (e.g., gossip, complaining, negative comments about students and staff, and conflicts against administration), but instead focused on more important features in the schools, (e.g., effective counseling programs, strong peer relationships, and academic excellence among teachers and students). One counselor stated that she did not see herself as a "hero" to the students. She avoided inappropriate intrapersonal boundaries among students and faculty and collaborated with other professionals in order to help the student. This enabled her to leave the problems of the day at the school and not bring them home, which is often a cause of counselor burnout. Humbleness also allowed the counselors to seek a team approach to helping students by bringing in other counselors, faculty, and parents to assist in problem solving. Humble educators sought advice, their own personal counseling, further education, and mentors, which they attributed to their becoming more successful counselors. Finally, humbleness allowed counselors to convey their passion to students and peers.

Surprisingly, spirituality was found to be another of the most prominent features in the development and maintenance of passion in school counselors. Spirituality is a result of a counselor's upbringing and included such areas as organized religious practice, 
Bible teachings, giving to charities and other acts of benevolence, and a devotion to an essential set of moral beliefs. Most of the participants continued to practice their religion. While spirituality was most often seen in the practice of organized religion among the participants, it was also seen in other contemplative practices such as wilderness experiences and in exercise. Spirituality also included such practices as meditation, journaling, contemplation, personal value evaluations, and acts of charity. The participants in this study applied many spiritual concepts to their current work in the field and were not reticent to speak about their faith. Spirituality discussed in the interviews also appeared to be pragmatic in nature — the counselors brought their faith into their practice in practical ways. This includes praying for their students, applying biblical concepts to counseling, and having a vision for change in even the most difficult cases. An integral component of a counselor's spirituality was expressed in the characteristic of humbleness.

School counselors are responsible for a plethora of duties in the typical public school, including testing duties, lunchroom duties, special education paperwork, credit checks, scheduling, and other clerical duties (Bemak, 2000). Typical school counselors could easily spend the majority of time in the office working on these duties and have little contact time with students. Passionate counselors spend copious time outside of their offices, in places such as the hallways, classrooms, lunchrooms, and in various locations outside the school building. A synergetic relationship existed among counselors, students, and faculty. Counselors expended energy and social, emotional, and academic assistance to students and faculty and through this work received energy, encouragement, and recognition in return. The positive feedback loop motivated 
counselors to continue their passionate work, thus creating a synergetic relationship among counselors, faculty, parents, and student with passion at the center.

The passionate counselor's family of origin appears to be instrumental in the development of passion through positive self-esteem messages, spirituality, charity, and an emphasis on education. Most of the counselors in this study came from traditional, two-parent families with a religious upbringing. These familial relationships tended to be supportive, positive, and ongoing, and they continue to influence the counselors to remain passionate through a variety of life challenges. The counselors’ current family proved to be a source of strength, facilitating more maturity in counseling, and providing a refuge from the stresses of the job. As the counselors grew older and had children of their own, they were able to empathize in greater ways with students in their schools and had a more mature perspective on complex issues.

\section{Developing and Maintaining Passion: A Theory}

\section{Factors that Influence the Development of Passion}

A supposition on how school counselors develop and maintain passion began to emerge as I analyzed the participants’ interviews. Passionate counselors in this study were generally raised in religious, caring, and supportive homes where positive selfesteem and education were emphasized. Parental influence on developing passion is not surprising. Aptitude can come from inherited personality traits, dependence on the social environments, and the determination of cultural patterns that define certain areas of performance as important. Students who spent copious amounts of time with parents, who offered support, became good roles models, practiced intellectualism, and were well 
disciplined, generally had the greatest impact on their children (Csikszentmihalyi et al., 1997).

Spirituality and self-reflection played a large role in this upbringing. Church attendance, a fundamental moral code, Bible teachings, and other religious practices were not only taught, but modeled by the parents and siblings as well. While Christianity was the only religion practiced in this study, no one denomination was mentioned more often than others. Some aspects of spirituality were practiced in more contemplative modes, such as abundant time in the wilderness, exercising, journaling, and meditation. Overall health (Hall, Dixon, \& Mauzey, 2004) and spirituality are important topics in school counseling (Allen \& Coy, 2004). While a gap exists between a present dialogue about spirituality in the schools and research published (Sink, 2004), spirituality can be implemented into school counseling settings and result in overall wellness for the school counselor (Ingersoll \& Bauer, 2004). While some family dysfunction was discussed, all of the participants shared largely positive childhood and young adult experiences.

Counselors' families of origin spent large amounts of time helping others in charitable work, which embedded the caring attribute in the counselors as they sought out their graduate school opportunities. While some of the counselors no longer attend the church of their youth, many of them are still active in Christian activities, both public and personal. Passionate counselors recalled their childhood by describing experiences that shaped and molded their thinking to get involved in the helping profession, ultimately in the counseling profession. Largely absent was the concept that these counselors entered the profession or continue in the counseling field to heal or recover from a damaged past 


\section{Developing Passion}

1. Family of origin that encourages positive esteem, education, and practiced caring attributes.

2. Spirituality is an important part of upbringing. It is taught and modeled. An ongoing involvement in religion or introspection is important in this spirituality.

3. Positive and/or negative aspects of the counselor's childhood become motivation to help others.

\section{Maintaining Passion}

For the counselors in this study, the journey from high school and college into school counseling took a variety of avenues; however, once they became professional school counselors they relied on attributes such as self-care, a concern for others, humbleness, and a sense of positive self-esteem to become and remain successful. Selfcare is essential in the development of successful school counselors. The healthy school counselor takes care of every area of their life, (e.g., social, emotional, cognitive, physical, spiritual, and vocational realms) (Wilkerson \& Bellini, 2006). While relying on and building these attributes, passionate counselors began to practice several strategies, including developing positive peer relationships, which leads to collaborative efforts for school change (Lewis \& Borunda, 2006). Also, spending large amounts of time with students, and keeping professionally appropriate boundaries assisted the counselor to develop and maintain passion. As passionate counselors develop and maintain these attributes, they employ other strategies, which include enrolling in ongoing education, spending profuse time out of the office-in the business realm known as managing by walking around, (Peters \& Austin, 1985)—and maintaining ongoing spiritual practices. Recent research suggests a relationship between school counselors that practiced an 
authentic spiritual life and the ability to maintain appropriate job roles and job satisfaction (Bryant \& Constantine, 2006).

These skills and strategies were developed over several years and were the result of hard work, a humbleness to learn from others, educational opportunities, and purpose in counseling. The results and rewards of this professionalism in counseling (e.g., awards, recognition at conferences, career satisfaction, and verbal encouragements) resulted in ongoing passion for the profession and a strengthening of the above mentioned attributes, forming a synergetic relationship. The more the counselors practiced these ongoing strategies, the more rewards and recognitions they received and thus motivation to continue this passionate counseling. The exemplary counselors exhibited an obvious lack of bitterness, complaining, and other negative features often found in educational circles. All four retired participants had created a legacy in the counseling community and were still active in the counseling profession. Three retired counselors are teaching in counseling graduate level programs and the longest retired participant is still heavily involved in national and state-wide counseling organizations. Spending time and effort in professional organizations reduced the effects of burnout in school counselors (Butler \& Constantine, 2005). See Figure 1 below: 


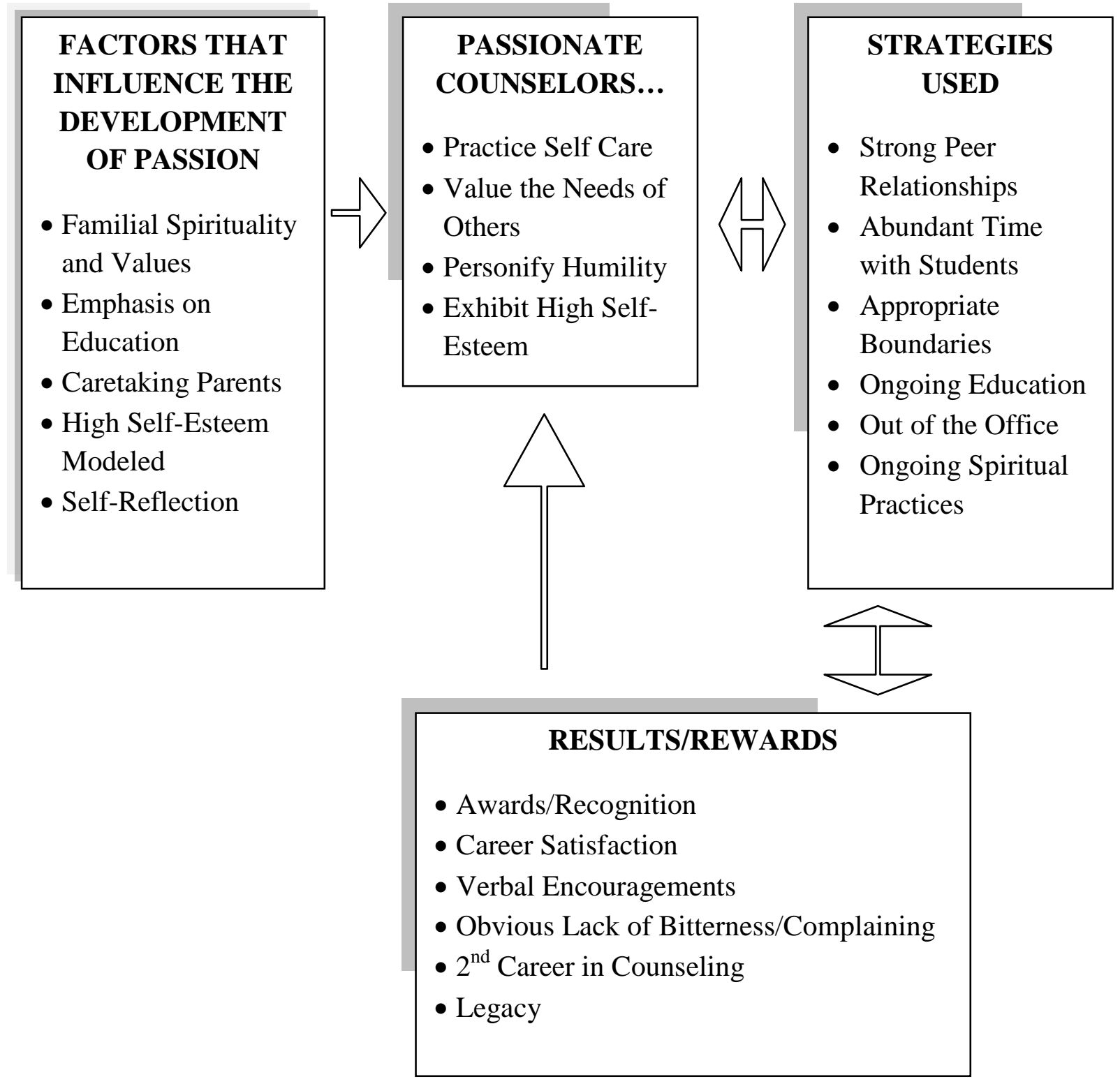

Figure 1. Theory of the development and maintenance of passion. 


\section{Passionate Leaders}

Educational literature (Hanushek, 2003; Littrell \& Peterson, 2005) indicates that exemplary educators exhibit attributes that drive student achievement. The passionate counselors in this study were performing at a high level and appeared to be leaders in their departments, schools, and districts. Several of the participants in this study are or have been department heads in their schools or had other leadership roles in the school, district, or in statewide counseling organizations. They were vital contributors on the faculty and collaborated with teachers, parents, and administrators to ensure student success. Passionate counselors utilized technology, recent research, and effective practices to build progressive and dynamic counseling departments and shared these experiences at a variety of local and state wide conferences.

Wiggins and Moody’s (1987) findings that counselors who were rated as more effective and were more involved in the direct delivery of counseling services, which was reflected in the activities of these passionate counselors. In this current study, the counselors were consistently innovators of unique and effective counseling programs in their schools and the counseling community. One participant initiated and developed a well known statewide conference attended by hundreds of counselors every year. Having been retired for 15 years, he still maintained significant involvement in this conference. Another counselor developed programs to assist troubled youth by taking them outdoors in the wilderness for retreats. Still others had moved beyond the public school setting into graduate level counselor education programs, thus teaching and training the next generation of school counselors. Informal conversations with their nominating peers also indicated exemplary features for these passionate professionals. The counselors in this 
study not only demonstrated passion, they passed it on to others and influenced the school and statewide counseling environment.

Caring, one feature found in passion (Liston, 2004; Noddings, 1992), was evidenced throughout the interviews, and resulted in a plethora of narratives about miracles in changed lives of troubled students from among the thousands in a counselor's caseload over the span of a career. One counselor, who had been retired for four years from her regular school counseling position, and was now substituting in a different school, eagerly shared current "miracle” stories—as she said, she was not done with her mission in life. Another counselor made visits to homes on a regular basis to help with family issues. In addition, one counselor shared a story about literally saving a student from a planned suicide and being a part of the student's amazing revitalization. Other interview participants took on the most troubled students in their school, regardless if they were in their caseloads.

\section{Keeping the Fire Going}

Keeping passion over the span of a career is a challenge for all educators. In part, passion requires connectedness among colleagues (Lewis, \& Borunda, 2006; Palmer, 1998). Strong peer relationships were modeled by the interviewees in this study.

Passionate counselors spoke often and in great detail about their ongoing relationships in the school environment. Exemplary relationships included family, faculty, and students; these relationships became a source of strength for the participants, especially during times of difficulty and challenge. Many of these relationships spanned several decades and at times produced tears as the counselors described them. 
Peters and Austin (1985) introduced to the business world the concept of managing by walking around, as they identified exemplary managers who spent profuse amounts of time walking the halls and public spaces of their workplaces. The participants in this study naturally practiced this in a variety of ways, (e.g., encouraging or counseling students, conferring with teachers, visiting homes, and living in “the students' world”)— they energetically worked with the people they served in their environments - not in the relative safety of their offices.

Their passion was a passion of action. It was seen in everyday activity in the school buildings, among the students, and resulted in a reputation being built among faculty and students. This allowed for greater access to the social world of the students and more effectiveness in ensuing individual counseling sessions. As public school counselors, the participants were able to increase the effectiveness of the various counseling programs as they reached more students with their message by spending valuable time in the classrooms, lunchrooms, and among groups of students and faculty. By using the attributes of humbleness, self-care, high self-esteem, and valuing the needs of others, they were able to resist the tendency to become embittered, unmotivated, and unproductive counselors.

Rockwell (2002) argued that we create our relational reality based on our passions and this passion "helps us to speak from our hearts and can draw out other people and engage them...this sense of pleasure and promise magnetizes others” (p. 52). Rockwell argued that this is such a powerful force that people "have to engage their passion without losing sight of the danger of getting caught up in or intoxicated by it...we don’t want to eliminate their passion; we want to cultivate it, refine it” (p. 184). Passionate 
counselors demonstrated the ability to use their passion for others' benefit and not for their own credit. Instead of drawing attention to their "greatness," they deferred to others or to their ongoing purpose in life - to make a positive mark on their students, peers, and schools.

While spending energy on their fledging careers and families, exemplary counselors also spent time away from the school environment and family and used their own funds on continuing their education through seminars, graduate classes, books, and workshops. The goal of this time spent away was the development of several growth factors, including cognitive features, emotional health, and relational maturity (Skovholt \& Jennings, 2004). These growth factors also included the physical and spiritual aspects of their personhood (Loehr, 2007).

A phenomenological study often results in an exhaustive description of the researched phenomenon (Creswell, 2007) in the context of a study. The results of the nine interviews were a rich, detailed, and textured description of a passionate school counselor in the public school environment, which resulted in an exhaustive description of these nine school counseling professionals. 


\section{Exhaustive Description of a Passionate School Counselor}

\section{Exhaustive Description of a Passionate School Counselor}

The phenomenon of passion in school counseling is an obvious, visible, and tangible attribute resulting in counselors that perform in an energetic and enthusiastic manner among students, teachers, administration, and families. These counselors generally go far beyond their prescribed duties and are able to perform at this high level despite common life challenges and lifespan issues. Passionate counselors operate from an "inner landscape” (Palmer, 1998, p. 8) that values a high level of service, care, compassion, and empathy. Passionate counselors also display humbleness about their work with students and ascribe much of their success in counseling to their God, mentors, and/or colleagues. They can be found out of their offices among the faculty and students and are innovators of new and effective programs that sustain themselves over the arc of their careers. Passionate counselors tend to come from strong, religious, and supportive families and appear to continue this custom in their current families. After retirement they are found to be heavily involved in the counseling profession in local and state-wide organizations and in the field of counselor education.

\section{Burnout Prevention}

The genesis of this study was in response to a public and personal perception of burned out and ineffective school counselors who are portrayed in our culture, schools, and various media. Indeed the burnout rate among all educators is high (Akos \& Scarborough, 2004). Stress factors for counselors include personal trauma, client behavior, work environment, and a lack of relationship support (Pearlman \& MacIan, 
1995). These stresses can be a result of counselors being over-involved in the counseling process and not receiving enough support from their peers and mentors (Coster \& Schwebel, 1997). An increase in paperwork, administrative duties, and a lack of support systems all contribute to a poor work environment and add to stress levels (Skovholt \& Jennings, 2004). The participants in this study seemed to be relatively impervious to these factors. In addition, by employing a variety of strategies the counselors effectively dealt with creeping fatigue- the ongoing downward pull of working in a complex social and educational environment with hundreds of troubled adolescents. While they endured many challenging life situations, including divorce, children's mental illnesses, death of a spouse, and other tragedies, they continued on a positive trajectory of growth in the attribute of passion.

Administrators, teachers, and counselors face a high rate of burnout among their peers (Henderson et al., 2006) and yet passionate counselors have found a way to not only stay in the profession, but to remain engaged at a high level. Counselors who lack passion may find themselves struggling to stay effective and many times resort to less productive practices, such as spending most of their time in their offices with paperwork, negative faculty lounge talk, and not attending appropriate professional development opportunities. A description of a non-passionate school counselor, (i.e., a burned out counselor and the antithesis of a passionate school counselor). 


\section{Description of a Non-Passionate School Counselor}

Non-passionate counselors may be found in many public and private schools. These counselors, while obtaining the proper academic degree to be licensed as a school counselor, perform their duties at a minimal level. They can generally be found in their offices, not working with students or faculty, spending abundant time on paperwork, waiting for the bell to signal the end of the work day, and being one of the first to leave the school building. Their work with students is often viewed as a burden and interruption to their day and not as an opportunity to change a life. Non-passionate counselors work for only the school district, without an authentic purpose in the field and do not have a core sense of values that drive their work. They can often become bitter when life challenges come their way; they struggle with finding purpose in their careers. Burnout is often a feature of their latter years. They rarely contribute to the counseling profession after retirement.

\section{Personal Reflections}

I had always been troubled by negative comments and misperceptions about my profession as a school counselor. Maybe I was overly sensitive to complaints, but it seems that most public references to school counselors were negative and demeaning. The media generally portrays school counselors as unorganized and incompetent (e.g., Lily Tomlin in Orange County) or lazy and uninvolved (as portrayed in the television series, Boston Public). While I knew counselors were vital and important professionals in a school environment, I wanted to help set the record straight. I desired to show a better 
side of school counseling. I wanted to explore examples of competent, energetic, and passionate counselors who work tirelessly for years, guiding, supporting, and literally changing the lives of thousands of students. I wanted to know how passion played a role in the lives of these nine counselors.

Living as a passionate counselor became a personal quest as I entered the latter years of my career. I vowed to not become someone simply waiting for retirement, but to grow and become even more engaged in this noble profession. I had always been fascinated by passionate people. They have a quality that sparks my own passions and are able to motivate me with an inspiring story or unique action that helped change a life.

There have been numerous studies conducted and books written on passion in the business world, (e.g., The Search for Excellence and Good to Great). These have proven useful, yet there is usually a bottom line that involves making more money and I found that to be somewhat incongruent with the counseling field. Counselors work with young people in a complex socio-economic and academic environment that demands passion, skill, compassion, and dedication. Taking into consideration the high burnout rate of professionals in education, developing, and maintaining passion is a vital component of school counselors' success. It was the purpose of this study to explore the phenomenon of passion by interviewing exemplary counselors (Littrell \& Peterson, 2005) noted to be passionate as they shared their thoughts, feelings, and experiences over the span of a career.

This study was also heuristic in nature. I am a school counselor who is seeking to increase my own passion in my professional life and this project supports the heuristic viewpoint in research (Krynski \& Tenenbaum, 2007). The six phases of heuristic research 
are an appropriate description of my personal experiences as a researcher. The first stage of initial engagement occurred when I became aware of my discontent in my professional counseling career. I had become stale in my passion and began thinking about a different career. I felt as if I had learned all there is to learn and became uninterested in further growth. The second phase, immersion, occurred as I began to learn about passion and the variety of perspectives around this subject. I read books, consulted with peers, and discussed this phenomenon with mentors. The third phase, incubation, happened as I continued working as a school counselor and contemplated the various features of passion in the counseling field. Illumination took place as I completed my research proposal and began connecting my study of passion with the collection of data through my interviews. During the fifth phase, explication, I conducted research and began to see a coming together of themes in the analysis of data and the implementations of passion in counseling. Finally, I continue to integrate this new knowledge into a creative synthesis, using personal reflection to become a more passionate counselor and educator. Connections between passion, spirituality, and counseling began to make sense (Krynski \& Tenenbaum, 2007).

Humbleness and Spirituality in the Schools

Most of my findings were congruent with recent studies on passion that are found in the business and educational literatures. Features such as strong ethics, postgraduate education, management by walking around, and connectedness to the school environment aligned with this literature. However, the propensity of humbleness and spirituality discussed in the interviews of these passionate counselors intrigued me. Humbleness was discussed in every interview and appeared pervasively throughout. While not extensively 
researched, it does appear in some literature and is important in school reform (Reville, 2005), teacher leadership (Ackerman, \& Mackenzie, 2006), and in the professional supervision of guidance counselors (Smythe, MacCulloch, \& Charmley, 2009). Spirituality, while written about much more frequently in the past decade, is often times “out of bounds” in counselor education graduate programs (Echterling, Cowan, Evans, McKee, Presbury, Staton, Stewart, \& Viere, 2002) and even more so in the public school setting (Lantieri, 2001; Sink, 2004). Yet when I spoke to those passionate about their roles as counselors, humbleness and spirituality were some of the most prominent features in our discussions.

Recognizing the contributions of spirituality in counselors is one feature of this study. Spirituality exists in our schools among faculty, administrators, and students alike. It is part of many of us-our experiences, values, sense of morals, and psyche. Recent surveys showed that the vast majority of Americans "view themselves as religious people and that spiritual growth is a large part of their lives” (Unte Reader, 2000, p. 78). Spirituality is one source that can give meaning to our lives and it is often viewed as part of our innate being (Lantieri, 2001). It has been my experience over the past 20 years in public education that speaking of spiritual features in my life was generally not tolerated and definitely not encouraged. To somehow leave this out in the parking lot at seven o'clock each morning and then to pick it up after work is not only impossible, but quite disingenuous and somehow false.

According to Nord (1995), not only are many of us spiritual professionals, but many of our students and peers likely are as well. Nord believes that we live and work in a community of spiritual people. Cultivating passion by developing a spiritual life is not 
something an educator can do by simply learning new techniques or spending a little time in a staff development day. Entering into a spiritual arena is an examination of who we are, what we believe about life's most important issues, and the meaning our life experiences bring into our professional lives. Kessler (2001) used the term "cauldron” (p. 126) to describe entering this emotional realm. In many ways, to be present in a spiritual way with our students and peers is a more precarious and challenging existence calling on all of our emotional features. While this involvement in spirituality calls us to do more, be more, and live a more authentic life than others may prefer, it often leads to a professional life of passion that will mean more to exemplary school counselors and those they may impact.

\section{Recommendations}

The data that emerged from this study became the source for recommendations to implement various features of passion in the public school environment. Maykut and Morehouse (1994) stated that the ultimate test of trustworthiness of a study is the determination of the researcher to find the results important enough to act upon. In this section I will make two recommendations for counselor educators, district administrators, and school leaders to consider.

In an Internet search of current writings and practices on humbleness and spirituality in school counselor graduate programs, few references to spirituality, humbleness, and passion were found in handbooks and manuals. In several books, spirituality was briefly acknowledged under the chapter heading for diversity issues and gave only scant information (Locke, Myers, \& Herr, 2000). Other books written for counseling graduate students (e.g., Echterling et. al, 2002; Sue \& Sue, 2002) offered little 
for the development of spirituality, passion, or humbleness in school counselors. When spirituality was covered it was mentioned in the context of tolerance and not as the development of the attribute. Recent counselor educator journals, (e.g., Counselor Educator and Supervision, and Professional School Counselor), had no recent substantial research on the topic. As a school counselor who has worked with many interns, I have never seen these subjects emphasized in the internship protocols. Discussions with other counselor educators from local graduate programs verify this. Making spirituality, humbleness, and the other attributes of passion more available to graduate students in text books, class project assignments, discussions, personal journaling, and in the internship process would allow for greater attention to the development of passion.

More attention on counselor professional development in the areas of passion, spirituality, humbleness, and spending time outside the office may prove helpful to novice and seasoned counselors. Occasionally seminar speakers at counselor conferences or staff development speakers may touch on the fringes of these topics, but then only rarely. One of the reasons for this is a perceived violation of "church and state" among educators. The First Amendment in the Constitution guarantees religious faith as a fundamental right of the individual. Basically the Constitution states that the government cannot do anything that promotes or undermines the practice of religion (Nord, 1995). Obviously there are parameters in case law (Sink, 2004) that define this issue in the public schools, but none restricts the ability of professional development professionals, counselors, teachers, and administrators to offer this topic in staff development offerings. Recent research discusses the need for a model to implement spirituality in the public school arena and how it might align with the ASCA model (Sink, 2004). Allowing for 
this kind of professional development to occur may not only support the development of passion in professional counselors, but also prove to mitigate the negative effects of difficult life challenges that occur for virtually all educators.

\section{Limitations}

While care was taken during this study to reduce my personal biases, some limitations may exist. I have been involved in a conservative Christian church for the past 28 years as a minister and active member and am comfortable speaking about my spirituality and personal faith. Also, the final course in my Ph.D. program, taken during the data collection time, entitled, "Spirituality and Religion in Education” covered spirituality in the public school setting, which may have led to some bias. This may have led me to demonstrate comfort during the spiritual discussions that evolved in the interviews, which in turn may have increased the amount of data related to spirituality. I will note, however, that the interviewees first broached the topic in virtually all the interviews, without my prompting.

Another limitation was having only a one-session interview. Even though I followed up with email interview questions for each participant, the data collected may have proven to be even richer and more nuanced by conducting a second face-to-face interview.

A final limitation may be the lack of diversity in the study, possibly due to snowball sampling that occurred in largely suburban school districts. All the participants were Caucasians from relatively affluent school districts in Colorado. While the data was 
quite powerful and descriptive, having more diversity may have provided a different cultural dimension to the study.

\section{Recommendation for Further Study}

The results of this study may lend themselves to several avenues of future studies. The use of humbleness and spirituality in the graduate school experience and how those attributes in turn relate to working in the school environment is a relatively new topic in the public school discourse (Lantieri, 2001; Sink, 2004) and warrants further research. Questions might include: What avenues might be used to teach humbleness? What are appropriate parameters in a public school for discussing spirituality? Would the introduction of spirituality in counseling prove to be more or less effective than more traditional modes of counseling? Research on the responsibility of counselor educators in teaching and modeling spirituality may be warranted.

Finally more research may be warranted to study the need for professional development in the schools to offer counselors the opportunity to develop and learn more about the essential features of a counselor's interpersonal experiences and how they might contribute to a more effective school counseling experience. 


\section{REFERENCES}

Ackerman, R., \& Mackenzie, S. (2006). Uncovering teacher leadership. Educational Leadership, 63, 13-17.

Adams, R., Figley, C., \& Boscarino, J. (2008). The compassion fatigue scale: Its use with social workers following urban disaster. Research on Social Work Practice, 18(3), 238-250.

Akos, P., \& Scarborough, J. (2004). An examination of the clinical preparation of school counselors. Counselor Education \& Supervision, 44, 96-107.

Adelman, H., \& Taylor, L. (2002). Building comprehensive, multifaceted, and integrated approaches to address barriers to student learning. Childhood Education, 78, 261268.

Allen, J., \& Coy, D. (2004). Linking spirituality and violence prevention in school counseling. Professional School Counseling, 7(5), 351-355.

American Psychiatric Association. (2000). Diagnostic and statistical manual of mental disorders, Text Revision (5 ${ }^{\text {th }}$ ed.). Washington, DC: American Psychiatric Association.

American School Counselor Association. (2008). Retrieved April 2, 2009 from http://schoolcounselor.org/content.asp

Anastasi, A., \& Urbina, S. (1997). Psychological testing. Upper Saddle River, NJ: Prentice Hall.

Anderson, R., \& Braud, W. (1998). Transpersonal research methods in social sciences: Applied social research methods. Thousand Oaks, CA: Sage.

Baggerly, J., \& Osborn, D. (2006). School counselors’ career satisfaction and commitment: Correlates and predictors. Professional School Counseling, 9(3), 197-205.

Battistich, V., Solomon, D., Watson, M., \& Schaps, E. (1997). Caring school communities. Educational Psychologist, 32, 137-151.

Belitz, C., \& Lundstrom, M. (1998). The power of flow: Practical ways to transform your life with meaningful coincidence. New York: Three Rivers Press. 
Bell, C. (1997). Passionate leadership. In K. Shelton (Ed.), A New paradigm of leadership: Visions of excellence for the $21^{\text {st }}$ century organizations. (1-9). Provo, UT: Executive Excellence.

Bemak, F. (2000). Transforming the role of the counselor to provide leadership in educational reform through collaboration. Professional School Counseling, 3(5), 323-331.

Bemak, F., \& Chung, R. (2008). New professional roles and advocacy strategies for school counselors: A multicultural/social justice perspective to move beyond the nice counselor syndrome. Journal of Counseling \& Development, 86(3), 372-381.

Bennett-Goleman, T. (2001). Emotional alchemy: How the mind can heal the heart. New York: Harmony Books.

Bonilla, A. (2006). Ten don’ts of successful school leadership. Principal Leadership, $6(7), 40-43$.

Boyatzis, R., McKee, A., \& Goleman, D. (2002). Reawaken your passion for work. Harvard Business Review, 80, 86-94.

Bryant, R., \& Constantine, M. (2006). Multiple role balance, job satisfaction, and life satisfaction in women school counselors. Professional School Counseling, 9(4), $265-271$

Buckingham. M. (2007). Go put your strengths to work. New York: Free Press.

Buckingham, M., \& Clifton, D. (2001). Now, discover your strengths. New York: Free Press.

Butler, S., \& Constantine, M. (2005). Collective self-esteem and burnout in professional school counselors. Professional School Counseling, 9, 55-62.

Churchill, W. (2003). Never give in: The best of Winston Churchill's speeches. New York: Hyperion.

Clandinin, D., \& Connelly, F. (2000). Narrative inquiry: Experience and story in qualitative research. San Francisco: Jossey-Bass.

Coffey, A., \& Atkinson, P. (1996). Making sense of qualitative data: Complementary research strategies. Thousand Oaks, CA: Sage.

Cole, D., \& White, K. (1993). Structure of peer impressions of children's competence: Validation of the peer nomination of multiple competencies. Psychological Assessment, 5, 449-458. 
Coster, J., \& Schwebel, M. (1997). Well-functioning in professional psychologists. Professional Psychology: Research and Practice, 28, 5-13.

Creswell, J. (1994). Research design: Qualitative and quantitative approaches. Thousand Oaks, CA: Sage.

Creswell, J. (2007). Qualitative inquiry and research design: Choosing among five traditions. Thousand Oaks, CA: Sage.

Csikszentmihalyi, M. (1996). Creativity: Flow and the psychology of discovery and invention. New York: HarperCollins.

Csikszentmihalyi, M., Rathunde, K., \& Whalen, S. (1997). Talented teenagers: The roots of success and failure. Cambridge, UK: Cambridge University Press.

Dahir, C., \& Stone, C. (2003). Accountability: A m.e.a.s.u.r.e. of the impact school counselors have on student achievement. Professional School Counselor, 6, 214221.

Damasio, A. (1999). The feeling of what happens: Body and motion in the making of consciousness. New York: Harcourt Brace.

Darling-Hammond, L. (2000). Solving the dilemmas of teacher supply, demand, and standards: How we can ensure a competent, caring and qualified teacher for every child. New York: National Commission on Teaching and America's Future.

Dollarhide, C., Gibson, D., \& Saginak, K. (2008). New counselors' leadership efforts in school counseling: Themes from a year-long qualitative study. Professional School Counseling, 11(4), 262-271.

Echterling, L., Cowan, E., Evans, W., McKee, E., Presbury, J., Staton, A., Stewart, A., \& Viere, G. (2002). Thriving!: A manual for students in the helping professions. Boston: Houghton Mifflin Press.

Fitch, T., \& Marshall, J. (2004). What counselors do in high-achieving schools: A study on the role of the school counselor. Professional School Counseling, 7, 172-177.

Fong, M. (1998). Considerations of a counseling pedagogy. Counselor Education and Supervision, 38, 1-4.

Friedman, S., DeGroot, J., \& Christensen, P., (Eds.). (1998). Integrating work and life: The Wharton resource guide. San Francisco: Jossey-Bass Pfeiffer.

Frijda, N. (2000). The psychologists point of view. In M. Lewis \& L. Haviland-Jones (Eds.), Handbook of Emotions. New York: Guilford Press. 
Gibran, K. (1992). The prophet. New York: Alfred A. Knopf.

Gibson, S., \& Hanes, L. (2003). The contribution of phenomenology to HRD research. Human Resource Development Review, 2(2), 181-205.

Goldstein, L. (1999). The relational zone: The role of caring relationships in the coconstruction of mind. American Educational Research Journal, 36, 647-673.

Goleman, D. (2006). Social intelligence: The revolutionary new science of human relationships. New York: Random House.

Goleman, D., Boyatzis, R., \& McKee, A. (2002). Primal leadership: Learning to lead with emotional intelligence. Boston: Harvard Business School Press.

Goodlad, J. (1984). A place called school: Prospects for the future. New York: McGrawHill.

Guiffrida, D. (2005). The emergence model: An alternative pedagogy for facilitating self reflection and theoretical fit in counseling students. Counselor Education \& Supervision, 44, 201-211.

Hall, C., Dixon, W., \& Mauzey, E. (2004). Spirituality and religion: Implications for counselors. Journal of Counseling \& Development, 84(4), 504-507.

Hanushek, E. (2004). The revolving door. Education Next, 4, 77-82.

Henderson, P., Cook, K., Libby, M., \& Zambrano, E. (2006). “Today I feel like a professional counselor!” Developing a strong professional school counselor identity through career experiences. Guidance and Counseling, 21, 128-142.

Higgins, M. (2005). Caught in the middle: A counselor's call to action. Professional School Counseling, 9(2), 171-172.

Hillerbrand, E., \& Claiborne, C. (1990). Examining reasoning skill differences between expert and novice counselors. Journal of Counseling and Development, 68, 684691.

Hinkle, J., \& Weisburd, D. (2008). The irony of broken windows policy: A micro-place study of the relationship between disorder, focused police crackdowns, and fear. Journal of Criminal Justice, 36(6), 503-512.

hooks, b. (1994). Teaching to transgress. New York: Routledge.

Hoshmand, L. (2006). Culture, psychotherapy, and counseling: Critical and integrative perspectives. Thousand Oaks, CA: Sage. 
House, R., \& Sears, S. (2002). Preparing school counselors to be leaders and advocates: A critical need in the new millennium. Theory Into Practice, 41, 1-11.

Ingersoll, E., \& Bauer, A. (2004). An integral approach to spiritual wellness in school counseling settings. Professional School Counselor, 7(5), 301-308.

Jensen, D. (2004). Walking on water: Reading, writing and revolution. White River Junction, VT: Chelsea Green Publishing.

Kelling, G. (1996). Fixing broken windows: Restoring order and reducing crime in our communities. New York: Martin Kessler Books.

Kessler, R. (2001). Soul of students, soul of teacher: Welcoming the inner life to school. In L. Lantieri (Ed.), Schools with spirit: Nurturing the inner lives of children and teachers (pp. 107-131). Boston: Beacon Press.

Kouzes, J., \& Posner, B. (1993). Credibility: How leaders gain and lose it, why people demand it. San Francisco: Jossey-Bass.

Krynski, T., \& Tenenbaum, J. (2007).The role of causality in judgment under uncertainty. Journal of Experimental Psychology, 136(3), 430-450.

Lambie, G., Davis, K., \& Miller, G. (2008). Spirituality: Implications for professional school counselors’ ethical practice. Counseling and Values, 52(3), 211.

Lambie, G., \& Williamson, L. (2004). The challenge to change from guidance counseling to professional school counseling: A historical perspective. Professional School Counseling, 8, 124-132.

Lantieri, L. (2001). Schools with spirit: Nurturing the inner lives of children and teachers. Boston: Beacon Press.

Lewis, R., \& Borunda, R. (2006). Lived stories: Participatory leadership in school counseling. Journal of Counseling \& Development, 84(4), 406-413.

Lieblich, A., Tuval-Mashiach, R., \& Zilber, T. (1988). Narrative research: Reading, analysis, and interpretation. Thousand Oaks, CA: Sage.

Lincoln, Y., \& Guba, E. (1985). Naturalistic inquiry. Beverly Hills, CA: Sage.

Liston, D. (2000). Love and despair in teaching. Educational Theory, 50, 81-102.

Liston, D., \& Garrsion, J. (2004). Teaching, learning and loving: Reclaiming passion in educational practice. New York: RoutledgeFalmer.

Littrell, J. (1998). Brief counseling in action. New York: W. W. Norton. 
Littrell, J., \& Peterson, J. (2005). Portrait and model of a school counselor. Boston: Houghton Mifflin.

Locke, D., Myers, J., \& Herr, E. (2000). The handbook of counseling. Thousand Oaks, CA: Sage.

Loehr, J. (2007). The power of story: Rewrite your destiny in business and in life. New York: Free Press.

Loehr, J., \& Schwartz, T. (2003). The power of full engagement: Managing energy, not time, is the key to high performance and personal renewal. New York: Free Press.

Lum, C. (2003). A guide to state laws and regulations on professional school counseling. Alexandria, VA: American Counseling Association Office of Public Policy \& Legislation.

Mallory, B., \& Jackson, M. (2007). Balancing the load: How to engage counselors in school improvement. Principal Leadership, 7(8), 34-37.

Maslach, C. (2005). Burnout: The cost of caring. Englewood Cliffs, NJ: Prentice Hall.

Maucieri, L., Gernand, R., \& Patelis, T. (2002). The College Board national high school survey report. New York: The College Board.

Maxwell, J. (1998). Designing a qualitative study. In L. Bickman \& D. Roget (Eds.), Handbook of success and failure. Cambridge: Cambridge University Press.

Maykut, P., \& Morehouse, R. (1994). Beginning qualitative research: A Philosophic and practical guide. New York: RoutledgeFalmer.

McCalip, R. (2001). Development of the secure counselor: Case examples supporting Pistole \& Watkins's (1995) discussion of attachment theory in counselor supervision. Counselor Education \& Supervision, 41, 18-27.

McDonough, P. M. (2005). Counseling and college counseling in America's high schools. In D. A. Hawkins \& J. Lautz (Eds.), State of college admission (pp. 107121). Washington, DC: National Association for College Admission Counseling.

McGlothlin, J., \& Miller, L. (2008). Hiring effective secondary school counselors. NASSP Bulletin, 92(1), 61-72.

Merriam, S. (1998). Qualitative research and case study applications in education. San Francisco: Jossey-Bass

Miles, M., \& Huberman, A. (1994). Qualitative data analysis. Thousand Oaks, CA: Sage. 
Mitroff, I., \& Denton, E. (1999). A spiritual audit of corporate America. San Francisco: Jossey-Bass.

Moles, O. (1997). Reaching all families: Creating family friendly schools. Washington, DC: U.S. Department of Education.

Moustakas, C. (1994). Phenomenological research methods. Thousand Oaks, CA: Sage.

Noddings, N. (1992). The challenge to care in schools: An alternate approach to education. New York: Teachers College Press.

Nord, W. (1995). Religion \& American education: Rethinking a national dilemma. Chapel Hill, NC: The University of North Carolina Press.

O’Brien, T. (1991). The things they carried. Thousand Oaks, CA: Sage.

Otero, V. (2003). Cognitive processes and the learning of physics. Part I: The evolution of knowledge from a Vygotskian perspective. Proceedings of the International School of Physics “Enrico Fermi” Course CLVI Italian Physical Society (409445). Amsterdam: IOS Press.

Palmer, P. (1998). The courage to teach. San Francisco: Jossey-Bass.

Palmer, P. (2004). A hidden wholeness: The journey toward an undivided life. San Francisco: Jossey-Bass.

Paterson, J. (2004). The changing role of school counselors. National Middle School Association. Retrieved January 31, 2009, from http://www.nmsa.org/Publications/ MiddleGround/Articles/August2004/tabid/169/

Patton, M. Q. (2001). Qualitative research \& evaluation methods (3 ${ }^{\text {rd }}$ ed.). Thousand Oaks, CA: Sage.

Pearlman, L., \& MacIan, P. (1995). Vicarious traumatization: An empirical study on the effects of trauma work on trauma therapists. Professional Psychology, Research and Practice, 26, 558-565.

Peters, T., \& Austin, N. (1985). A passion for excellence: The leadership difference. New York: Random House.

Polkinhorne, D. E. (1995). Narrative configuration in qualitative analysis. Qualitative Studies in Education, 8, 5-23.

Prochaska, J. (2006). Common problems: Common solutions. Clinical Psychology: Science and Practice, 2(1), 101-105. 
QSR. (2007). NVivo. QSR International.

Reisetter, M., Korcuska, J., Yexley, M., Bonds, D., Nikels, H., \& McHenry, W. (2004). Counselors educators and qualitative research: Affirming a research identity. Counselor Education \& Supervision, 44, 2-15.

Reville, P. (2005). Humility and school reform. Journal of Education, 186, 9-21.

Richards, L. (2005). Handling qualitative data: A practical guide. Thousand Oaks, CA: Sage.

Rivkin, S., Hanushek, E., \& Kain, J. (2002). Teachers, schools and academic achievement. Retrieved July 23, 2008, from http://edpro.standford.edu/eah/down.htm.

Rockwell, I. (2002). The five wisdom energies: A Buddhist way of understanding personalities, emotions, and relationships. Boston: Shambhala.

Rogers, C. (1961). On becoming a person: A therapist's view on psychotherapy. London: Constable.

Rubin, J. (2006). Psychotherapy and Buddhism: Toward an integration. New York: Plenum.

Sanborn, M. (2004). The Fred factor. New York: Doubleday.

Schmidt, J. (1999). Counseling in schools: Essential services and comprehensive programs. Needham Heights, MA: Allyn and Bacon.

Senge, P., Kleiner, A., Roberts, C., Ross, R., Roth, G., \& Smith, B. (1999). The dance of change: The challenges to sustaining momentum in learning organizations. New York: Doubleday.

Shank, G. (2006). Qualitative research: A personal skills approach. Columbus, OH: Merrill Prentice Hall.

Sheehy, G. (1995). New passages: Mapping your life across time. New York: Random House.

Shorter Oxford English Dictionary on Historical Principles (5 ${ }^{\text {th }}$ ed.). (2002). Oxford: Oxford University Press.

Sink, C. (2004). Spirituality and comprehensive school counseling programs. Professional School Counseling, 7(5), 309-317. 
Skovholt, T., \& Jennings, L. (2004). Master therapist: Exploring expertise in therapy and counseling. Boston: Pearson.

Skovholt, T. \& Ronnestad, M. (1992). Themes in therapist and counselor development. Journal of Counselling and Development, 70, 505-515.

Smith, S., Crutchfield, L., \& Culbreth, J. (2001). Teaching experience for school counselors: Counselor educators’ perceptions. Professional School Counseling, 4, 21-224.

Smythe, E., MacCulloch, T., \& Charmley, R. (2009). Professional supervision: Trusting the wisdom that comes. British Journal of Guidance \& Counselling, 37, 17-25.

Solomon, G., \& Perkins, D. (1998). Individual and social aspects of learning. Review of Research in Education, 23, 1-24.

Strauss, A., \& Corbin, J. (1990). Basics of qualitative research. Newbury Park, CA: Sage.

Strongman, K. (1996). The psychology of emotion: Theories of emotion in perspective ( $4^{\text {th }}$ ed.). New York: John Wiley \& Sons.

Sue, D., \& Sue, D. (2002). Counseling the cultural diverse: Theory and practice. New York: Jossey-Bass.

The Holy Bible New International Version. (1984). International Bible Society. Colorado Springs: Zondervan.

Thompson, R. (1992). School counseling renewal: Strategies for the twenty-first century. Muncie, IN: Accelerated Development.

Timpson, W. (2002). Teaching \& learning peace. Madison, WI: Atwood.

Timpson, W. Borrayo, E., Canetto, S., \& Yang, R. (2003). Teaching diversity: Challenge and complexities, identities and integrity. Madison, WI: Atwood.

U.S. Department of Education. (2004). The condition of education. Jessup, MD: ED Pub.

U.S. Department of Labor. (2008). Occupational outlook handbook. New York: Skyhorse.

Van Esbroeck, R. (1998). The changing role of guidance counsellors in Flanders. International Journal for the Advancement of Counselling, 20(1), 45-60.

WICHE (2004). Staying the course: WICHE 2004 annual report. Retrieved March 21, 2009 from http://www.wiche.edu/annualreport04/conahec.as 
Wiggins, J., \& Moody, A. H. (1987). Student evaluations of counseling programs: An added dimension. The School Counselor, 34, 353-361.

Wilkerson, K, \& Bellini, J. (2006). Intrapersonal and organizational factors associated with burnout among school counselors. Journal of Counseling \& Development, 84(4), 440-450.

Wrzesniewski, A. (2001). Crafting a job: Revisioning employees as active crafters of their work. Academy of Management Review, 26(2), 179-201.

Zaltman, G. (1996). Metaphorically speaking. Marketing Research, 8, 13-22.

Zaltman, G. (2003). How customers think: Essential insights into the mind of the market. Boston: Harvard Business School Press. 


\section{APPENDIX A \\ PROCEDURES SUMMARY}

The research design of this study will be qualitative with a phenomenological approach. Personal interviews will be the primary means of data collection.

The sample will be school counselors who have been selected from supervisors or peers. The selected sample will be between 12 and 20 counselors or until saturation is reached.

The focus of this study will be on the phenomenon of passion and those counselors who have demonstrated success in the totality of their careers. In addition to nomination for this study three other selection criteria specific to this study will be applied to the recruitment of participants. These criteria are:

1. The participant must have at least 15 years of experience in the school setting.

2. The participant must be able to participate in a personal interview in their office in fall, 2008 or spring, 2009 (after hours) or in another location acceptable to the participant and the researcher. The participant must be available for an email follow-up interview as well as be able to review interview transcripts and provide related feedback.

3. The participant must be willing to participate given the risk/benefit and confidentiality precautions of the study as approved by the CSU Human Subjects approval process.

All of the nominees who meet the selection criteria will be contacted personally or via telephone or e-mail with a request to participate in this study beginning in fall, 2008. If he or she is interested in participating they will be sent more detailed information 
on the study including the consent and confidentiality procedure. Each potential participant will be contacted by telephone or e-mail to confirm their desire to participate and if affirmative an interview time will be scheduled. All participants who agree to an interview will be given an information packet including an introductory letter explaining the purpose of the study, a summary of the study procedures, and consent form.

Each participant who agrees to participate will be asked to take part in a three cycle data collection and analysis procedure. Each participant will be interviewed inperson once and follow-up email questions. The interviews will be audio recorded for later transcription. Each participant will be offered the opportunity to review his or her transcripts during the follow-up email.

Data analysis will use the constant comparative analysis of open, axial and selective coding. This analysis will identify emergent themes from the experiences as related by the participants.

This study will be conducted under the approval of the CSU Human Subjects protection system. The actual participants will be known only to the researchers. Special attention will be paid in the IRB and the informed consent process to make participants aware that due to their small numbers and their notoriety in the field that their identity may be able observed in the data and final report. 
APPENDIX B

\section{INITIAL RECRUITMENT}

Email sent to Counseling Department Heads, District Officials and Principals:

Dear Counselor,

My name is Timothy Sumerlin and I am currently a doctoral candidate at Colorado State University, completing my dissertation. The title of my dissertation is The Heart of the School Counselor: Understanding Passion over the Span of a Career. The overall purpose of this study is to examine how the phenomenology of passion is developed and maintained in exemplary counselors over the span of a career.

I am requesting that you send me the name of a counselor in your department who has demonstrated passionate (energetic, enthusiastic, compassionate) counseling during their career (15 years or more in education). After verification, this counselor may be asked to participate in two interviews (one in their office and an email follow-up) after school hours to help me in this project.

I appreciate your help in this matter. If you have any questions please call me at the number below.

Thank You,

Timothy Sumerlin

303.518 .0451 
APPENDIX C

PARTICIPANT INTRODUCTION LETTER

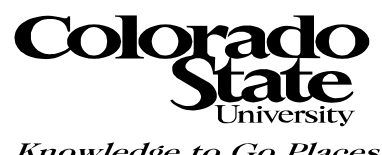

Dear Counselor,

Thank you for agreeing to participate in my doctoral research. The title of my dissertation is The Heart of the School Counselor: Understanding Passion over the Span of a Career. You have been chosen as a participant in this study because you have received nominations from colleagues and as such have demonstrated a career of passionate counseling in education.

The overall purpose of this study is to examine how the phenomenology of passion is developed and maintained over the span of a career. Data gathered will be used to complete my dissertation at Colorado State University.

Before scheduling an interview with you I have to tell you about the requirements I must meet in conducting any research involving human subjects. Federal law and each educational institution regulate all research involving human subjects. There are strict requirements for confidentiality, informed consent and participant knowledge of the research purpose as well as risks and benefits to you as a participant. I have satisfied all CSU requirements in this regard. Dr. John Littrell of the CSU School of Education is the Principal Investigator on this study and I am working directly under his supervision.

All of our communication will be strictly confidential. I will not produce any documents, reports or articles that identify you, your current or past employers. However, because of the small number of participants in this study and your prominence in your school community it is possible that elements of your experience may be recognizable in the study. I will provide you with a copy of the completed study at the completion of the project. I have included an informed consent form that I will need you to review and sign before you participate in any interviews. I will contact you within the next week via telephone or e-mail to schedule an interview time at your school.

Also, please look through your office and choose an artifact (picture, knick knack or gift) that illustrates passion for you and be ready to talk about that in the interview.

Thank you,

Timothy Sumerlin

Co-Investigator 


\section{APPENDIX D}

INFORMED CONSENT TO PARTICIPATE IN A RESEARCH PROJECT

TITLE OF PROJECT: The Heart of the School Counselor: Understanding Passion over the Span of a Career

NAME OF PRINCIPAL INVESTIGATOR: Dr. John Littrell, Ed.D.

NAME OF CO-INVESTIGATOR: Timothy L. Sumerlin, M.Ed.

CONTACT NAME AND PHONE NUMBER FOR QUESTIONS/PROBLEMS:

Dr. John Littrell 970.491.5160_john.littrell@colostate.edu

Timothy Sumerlin 303.518.0451_timothy.sumerlin@dcsdk12.org

\section{SPONSOR OF PROJECT: None}

PURPOSE OF RESEARCH: To research the phenomenon of passion in the counseling field over the span of a career.

PROCEDURES/METHODS TO BE USED: Your participation in this study is completely voluntary. If you agree to participate your participation will be one personal and one email follow-up interview with the Co-Investigator. The personal interview will take approximately 90 minutes and will be at the interviewee's office in fall 2008. The second interview will be an email follow-up interview. All interviews will be digitally recorded and then transcribed. At the conclusion of the study the recordings will be erased. You will be provided an opportunity to review the transcripts of each of your interviews. Your response to interview questions and other information provided in the course of the study will held in the strictest confidence. No information that could identify you individually will be provided to any other organization or current or past employer. You may terminate the interview at any time for any reason. You may also request that your data not be included in the final report.

RISKS INHERENT IN THE PROCEDURES: There are no known risks associated with your participation. It is not possible to identify all potential risks in research procedures, but the researcher(s) have taken reasonable safeguards to minimize any known, but unknown, risks.

Page 1 of 2, Subject Initials Date 
BENEFITS: There are no known direct benefits to you for your participation in this study. However, your experiences may help you gain new insights into the development and maintenance of passion in your life. This research will contribute to the knowledge base on of the phenomenon of passion in the field of education.

CONFIDENTIALITY: All data collected in this study will be combined to identify emerging themes. Your name or specific identifying information will not be associated with the data analysis process or with any reporting of results. The only people who will know your identity will be the Principal and Co-Investigators.

LIABILITY: The Colorado Governmental Immunity Act determines and may limit Colorado State University's responsibility if an injury happens because of this study. Claims against Colorado State University must be filed within 180 days of injury.

Questions about subjects' rights may be directed to Janelle Barker (Senior IRB Coordinator) at (970) 491-1655.

PARTICIPATION: Your participation in the study is voluntary. If you decide to not participate in the study, you may withdraw your consent and stop participating at anytime without penalty or loss of benefits to which you are otherwise entitled.

Your signature acknowledges that you have read the information stated and willingly sign this consent form. Your signature also acknowledges that you have received, and on the date signed, a copy of this statement containing two pages.

Participant name (printed)

Participant signature

Date

Witness to signature

Date

Page 2 of 2, Subject Initials Date 


\section{APPENDIX E}

\section{PRE-INTERVIEW COUNSELOR DEMOGRAPHIC SURVEY}

1. Gender $\square$ Female $\square$ Male

2. Age:

3. Ethnic group (Circle number)

1. White or European

2. Black or African American

3. Hispanic or Latino

4. Asian-American

5. Native-American

6. Native Hawaiian or Pacific Islander

7. Other (Please specify)

4. Primary location of your school setting (Circle number)

1. Rural

2. Urban

3. Suburb

5. Highest level of education completed (Circle number)

1. Bachelor's

2. Master's

3. Doctorate

6. School settings where you are a counselor (Circle as many as apply)

1. Elementary school

2. Middle School

3. High School

7. _ـ Y Year you received a counseling degree (NA = Not Applicable)

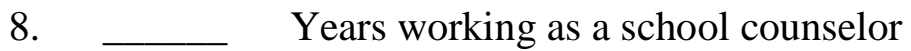

9. __ Number of different schools you currently work in as a counselor

10. __ Number of students you are responsible for as a counselor

11. __ The Student-to-Counselor ratio in your school(s) is how many students to 1 counselor

12. _ $\%$ Percent of Students-of-Color in your school(s)

13. In my job as a counselor, I typically work hours per week. 


\section{APPENDIX F}

\section{INTERVIEW SCRIPT}

The guiding or grand tour question for this interview is:

How have you as an exemplary school counselor developed and maintained passion over the span of your career? By passion I'm referring to energetic, enthusiastic and compassionate work that you believe is evident to your students and staff.

Secondary questions include:

What strengths enable you as a school counselor to develop and maintain passion during difficult and/or challenging times, such as through life stages (marriage, childbirth, parenting, divorce, aging, retirement), difficult working environment, and demanding work load?

How has your individual passion changed the culture of a counseling department and/or school?

Use an artifact from your office to describe your passion.

How does passion relate to your role as a counselor?

What role has your relationships played in this development both inside and outside the counseling profession?

$>$ How have these attributes been emphasized through professional development in the school or district setting?

How helpful or not helpful is the school and/or district professional development program in this professional growth? 


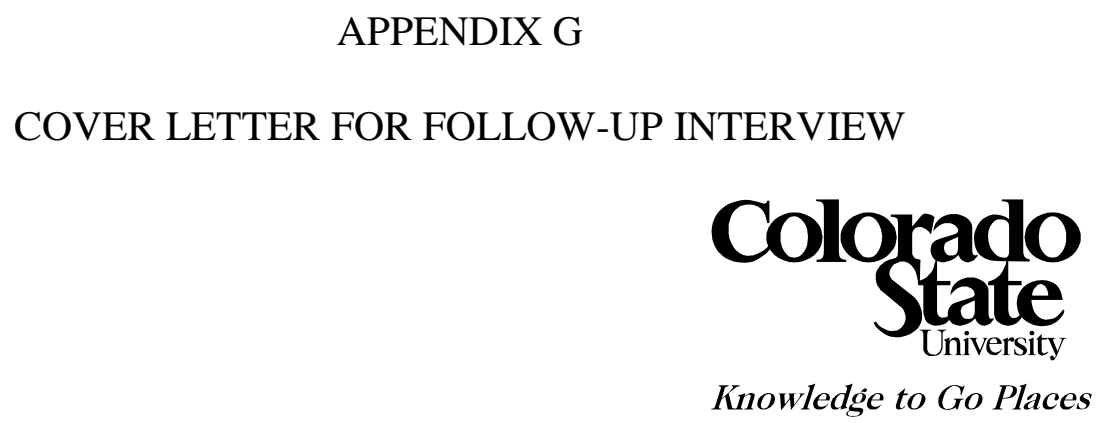

Date

Dear Counselor,

Thank you for participating in my research. I enjoyed our first interview and I'm preparing to continue our conversation with a follow-up email interview. I'll be sending you information on this soon.

I will be sending you a narrative summary. A narrative summary is essentially the retelling of your experiences as I heard them. Please read this and be prepared to elaborate on or add to it at the follow-up email. It is important that I represent and interpret your experiences correctly.

Thank you again and I'll be in contact with you soon.

Timothy Sumerlin

timothy.sumerlin@dcsdk12.org

303.518.0451 


\section{APPENDIX H \\ FOLLOW-UP INTERVIEW QUESTIONS}

$>$ After reading the transcript of our first interview would you like to elaborate on anything?

$>$ One of the themes that seem to come through in the first interview was . Could you tell me more about that?

$>$ You said, “ ” which surprised me. Can you tell me more about that?

$>$ What wisdom regarding passion would you give a first-year counselor concerning passion? 5-year veteran? 10-year?

$>$ Anything else you may want to elaborate on? 